\title{
Ketanserin and hypertension in cardiac surgery
}

Citation for published version (APA):

van der Starre, P. J. A. (1988). Ketanserin and hypertension in cardiac surgery. [Doctoral Thesis, Maastricht University]. Rijksuniversiteit Limburg. https://doi.org/10.26481/dis.19880226ps

Document status and date:

Published: 01/01/1988

DOI:

$10.26481 /$ dis.19880226ps

Document Version:

Publisher's PDF, also known as Version of record

\section{Please check the document version of this publication:}

- A submitted manuscript is the version of the article upon submission and before peer-review. There can be important differences between the submitted version and the official published version of record.

People interested in the research are advised to contact the author for the final version of the publication, or visit the DOI to the publisher's website.

- The final author version and the galley proof are versions of the publication after peer review.

- The final published version features the final layout of the paper including the volume, issue and page numbers.

Link to publication

\footnotetext{
General rights rights.

- You may freely distribute the URL identifying the publication in the public portal. please follow below link for the End User Agreement:

www.umlib.nl/taverne-license

Take down policy

If you believe that this document breaches copyright please contact us at:

repository@maastrichtuniversity.nl

providing details and we will investigate your claim.
}

Copyright and moral rights for the publications made accessible in the public portal are retained by the authors and/or other copyright owners and it is a condition of accessing publications that users recognise and abide by the legal requirements associated with these

- Users may download and print one copy of any publication from the public portal for the purpose of private study or research.

- You may not further distribute the material or use it for any profit-making activity or commercial gain

If the publication is distributed under the terms of Article $25 \mathrm{fa}$ of the Dutch Copyright Act, indicated by the "Taverne" license above, 


\section{Ketanserin and hypertension in cardiac surgery}





\section{Ketanserin and hypertension in cardiac surgery}

\section{Proefschrift}

ter verkriiging van de graad van doctor in de geneeskunde aan de

Rijksuniversiteit Limburg te Maastricht, op gezag van de Rector Magnificus Prof. Dr. F.l.M. Bonke, volgens het besluit van het

College van Dekanen, in het openbaar te verdedigen op vrijdag 26 februari 1988 om vier uur

door

Pieter Jacobus Adriaan van der Starre

geboren te Tegal in Indonesië 
Promotor : Prof. Dr. R.S. Reneman

Referenten: Prof. Dr. J.G. Bovill

Prof. Dr. S. de Lange

ISBN 9090020853 
To the memory of Christine

To my parents

To Annèt, Daniël, Heingen and Taco 



\section{Contents}

1. General introduction

1.1 Hypertension

1.2 Agents for acute treatment of hypertension

1.3 Serotonin

1.4 The aim of the thesis

2. The pharmacology of ketanserin

3. Anesthetic and surgical techniques and postoperative management

3.1 Anesthetic technique and monitoring

3.2 Surgical technique

3.3 Cardiopulmonary bypass 29

3.4 General postoperative management $\quad 30$

4. Ketanserin during and following coronary artery bypass grafting: hemodynamic and humoral responses

5. The use of ketanserin for treatment of postoperative hypertension following coronary artery bypass surgery

6. Ketanserin in the treatment of postoperative hypertension following coronary artery bypass grafting: a double blind study

7. Nitroprusside and ketanserin in the treatment of postoperative hypertension following coronary artery bypass grafting: a haemodynamic and ventilatory comparison

8. Ketanserin in the treatment of pulmonary hypertension following valvular surgery: a comparison with sodium nitroprusside 
9. The alpha-adrenergic receptor blocking effect of ketanserin and the interaction between alphaadrenergic and $\mathrm{S}_{2}$-serotonergic receptor blockade in lowering blood pressure in man

10. Peripheral vascular effects of ketanserin and nifedipine during cardiopulmonary bypass

11. General discussion

12. Summary

13. Samenvatting

14. References 
Chapter 1

General introduction 


\subsection{Hypertension}

One of the most important problems the anesthesiologist is confronted with during cardiac surgery, particularly coronary artery bypass surgery, is the prevention and treatment of systemic hypertension. In general, patients who are suffering from coronary artery occlusive disease, are treated with beta-blocking agents, calcium entry blockers and nitrates, but nevertheless systernic hypertension frequently occurs during the surgical procedure. Not only in patients with coronary artery disease, but also in patients with congestive heart failure due to progressive valvular disease, like aortic valve stenosis and mitral valve insufficiency, hypertension may lead to increased oxygen demands of the already compromised myocardium, occasionally resulting in myocardial ischemia and infarction (Moffitt et al.1985, Moffitt and Sethna 1986, Merin et al.1986, Slogoff and Keats 1986).

The most threatening moments are intubation (Forbes and Dally 1970 , Wycoff 1960, Fox et al.1977), sternotomy and sternal spread (Low et al.1986). The cause of the hypertensive episodes at these moments is stimulation of the sympathetic nervous system, causing an increase in the levels of circulating catecholamines (noradrenaline and adrenaline) and, as a consequence, elevated blood pressure associated with an increase in systemic and pulmonary vascular resistance and heart rate (Roberts et al.1977, Wallach et al.1980, Balasaraswathi et al.1978,1982, Kim et al.1981, Estafanous and Tarazi 1980, Estafanous et al.1984, Low et all.1986). Increased plasma renin activity and angiotensin-II-levels have been reported to contribute as well. Because of the fact that most of the patients receive beta blocking agents preoperatively, heart rate does not change as often as blood pressure (Sill et al.1984).

In the course of cardiopulmonary bypass the levels of circulating catecholamines increase, causing an increase in systemic vascular resistance (Engelman et al.1983, Reves et al.1982). The levels of renin and angiotensin II increase as well (Townsend et al.1984), in spite of the use of pulsatile flow (Taylor et al.1979, Salerno et al.1981, Azariades et al.1986, Anton et al.1964). Others investigators have reported increases in vasopressin-levels (Hawkins et al.1986,1983, Knight et al. 1986, Chambers et al.1984). The mechanisms involved in the increases in plasma levels of circulating catecholamines and renin-angiotensin during cardiopulmonary bypass are speculative: hemodilution (Hine et al.1976), initial hypotension, hypothermia (Chernow et al.1983, Arnett and Watts 1960), non-pulsatile flow, decreased levels of beta-blocking agents (Cooper et al.1985, Bolling et al.1984) and a chemoreceptor reflex (Brown 1979) have been proposed. In the early postbypass period hypertension does not frequently occur, 
since the heart has to recover from the effects of the cardioplegic solution and the ischemic episode during aortic cross-clamping. In addition a low systemic vascular resistance is abserved following termination of cardiopulmonary bypass. The often observed drop in blood pressure during transportation to the Intensive Care Unit (ICU) (Wanov et al.1984), as caused by acute movements of patients in a relatively unstable condition, contributes to the delay of the onset of hypertension in the immediate postoperative period (Insel et al.1986).

In the following hours in the ICU hypertension has been reported in 40 $60 \%$ of the patients following coronary artery bypass surgery, depending on the criteria applied and the actual condition of the patient (Estafanous et al.1973, 1978, Viljoen and Estafanous 1976). Apart from the factors, which are also responsible for the development of prebypass hypertension, the type of narcotic agents used might also contribute to the development of hypertension in the postoperative phase (Hardy et al.1983). Recently the contribution of the renin-angiotensin system for the development of postoperative hypertension was questioned (Weinstein et all.1987). Additional factors like hypothermia, resulting in peripheral vasoconstriction and shivering, arousal, intolerance to endotracheal intubation, hypercapnia, hypoxia and pain, may cause hypertension and tachycardia.

Hypertension should not only be prevented because of the risk of myocardial damage, but also because neurologic complications may occur (Sotaniemi 1980), which are often difficult to detect during general anesthesia and in the early postoperative period (Fremes et al.1983, Ivanovet al.1983, Kolkka and Hilberman 1980). Surgery can be complicated by an increase in blood loss because of hypertension, since the patients are heparinized. Even so it has been suggested that early hypertension is one of the causes of premature graft closure and accelerated atherosclerosis of saphenous vein grafts due to intimal damage (Brody et al.1972).

Serious bleeding, leading to a reintervention, is reported in 2 to $10 \%$ of the cases (Bachmann et al.1975), peri-operative myocardial infarction in 5 to $15 \%$ of the cases (Kirklin et al.1979) and neurologic deficit following cardiac surgery, mainly attributed to particulate matter (aggregates) and unstable blood pressure, has been reported in 1 to $31 \%$ of the cases, depending on the applied criteria (Slogoff et al.1982, Gonzales-Scarano and Hurting 1981, Utley and Stephens 1986). Studies on the causal relations, if any, between per and postoperative hypertension on the one hand and neurologic complications on the other still have to be performed.

During and following cardiac surgery systemic hypertension is routinely treated with a variety of compounds, mainly vasodilating agents. These antihypertensive drugs will be briefly discussed in the next section. Per- 
operatively inhalation anesthetics like halothane (Kien et al.1986, Cork et al.1985), enflurane (Heikkila et a.1985) or isoflurane (Fisherstrom et al.1985, Gunnicker et al.1986), have been applied to treat hypertension because of their vasodilating properties. Stellate ganglion blockade (Bidwai and Rogers 1979) or epidural anesthesia (Hoar el al.1976) have been advocated as preventive measures as well.

\subsection{Agents for acute treatment of hypertension}

Sodium nitroprusside is a potent, non-specific arterial and a moderate venous vasodilator, causing primarily a decrease in systemic vascular resistance and an increase in venous capacitance (Tinker and Michenfelder 1976, Kaplan et al.1980, Gustafson 1984, Gerson et al.1982). When hypovolemia is avoided, cardiac output will be enhanced. As an autonomic reflex heart rate increases, particularly at higher doses (Yaster et al.1986, Kaplan et al.1980). Some authors have reported unchanged cardiac output (Adams et al.1974, Stoelting et al.1977, Styles et al.1973) and unaffected stroke volume after the administration of nitroprusside (Wildsmith et al.1973, Rowe et al.1962). The main side effects are thiocyanate toxicity (Arnold et al.1984, Moore et al.1985b, Bloor et al.1985,Patel et al.1986), particularly in patients treated longer than 72 hours at high dose levels, and an increase in pulmonary shunting, possibly leading to hypoxemia (D'Oliveira et al.1981, Saarnivaara et al.1984, Seltzer et al.1976). In the case of coronary artery disease, reports on the development of a coronary steal-phenomenon during the administration of nitroprusside have been published (Hickey et al.1983). Recently nitroprusside was reported to cause an increase in plasma levels of circulating catecholamines and renin-angiotensin-activity (Knight et al.1983, Lagerkranser et al.1985).

Nitroglycerin, administered as a continuous infusion, is an effective antihypertensive compound (Thys et al.1985, Gallagher et al.1986, Gerson et al.1982, Cattaneo and Leier 1982), although failure to prevent intraoperative myocardial ischemia has been reported (Thomson et al.1984). This agent causes mainly wenous vasodilatation (Coriat 1986, Moffitt et al.1983), which is an advantage in patients undergoing cardiac surgery, because venous vasoconstriction often occurs during cardiopulmonary bypass. At higher dose levels nitroglycerin also causes arterial vasodilatation. Side effects are reflex tachycardia (Kaplan et al.1980), an increase in intrapulmonary shunting, although less pronounced than with nitroprusside (Berthelsen et al.1986, Flaherty et al.1982, Kopman et al.1978), acute methemoglobinemia (Zurick et al.1984, Robiczek 1985), and a dose-related prolongation of the bleeding time (Lichtenthal et al.1985). In 
coronary artery disease nitroglycerin improves coronary collateral flow without causing a steal phenomenon (Coriat et al.1984).

Of the ganglionic blocking agents trimetaphan has been studied best (Shell and Sobel 1974). Apart from the ganglionic blockade, this agent has direct vasodilating properties, and in higher concentrations an alphaadrenergic blocking action (Harioka et al.1984). It produces an increase in cardiac output and heart rate, probably as a consequence of parasympathetic ganglionic blockade. Histamine release and tachyphylaxis are important side-effect. Because of the ganglionic blockade no changes are observed in the plasma levels of catecholamines, renin and angiotensin (Fahmy and Soter 1985, Knight et al.1983). Chlorpromazine has a hemodynamic pattern similar to that of trimetaphan (Stinson et al.1975), but is generally intermittently administered.

Phentolamine, an alpha ${ }_{1}$ and alpha $_{2}$-adrenergic receptor blocking agent, reduces arteriolar resistance and, to a lesser degree, increases venous capacitance (Champoux and Gauthier 1984, El-Etr and Glisson 1978). Side effects are an increase in the levels of circulating catecholamines, tachycardia (Hoffman and Lefkowitz 1980), vomiting, diarrhoea, and sometimes exacerbation of peptic ulcer disease (Gould and Reddy 1976).

Phenoxybenzamine, a pure alpha $a_{1}$-adrenergic receptor antagonist, shows a similar pattern of action and has the same side-effects as phentolamine, but its duration of action is much longer ( El-Etr and Glisson 1978).

Dehydrobenzperidol (droperidol), a butyrophenon derivate, has alpha adrenergic receptor blocking properties (Whitwam and Russell 1971, Van Nueten et al.1977), but is mostly used as a neuroleptic agent in combination with a narcotic analgesic compound like fentanyl (Fox et al. 1967 , Graves et al.1975). The main side effects are reflex tachycardia and increased plasma levels of catecholamines (Radnay et al.1977, Ferrari et al.1974).

Hydralazine is mainly an arteriolar vasodilator with little effect on the venous capacitance vessels (Koch-Weser 1976), and with a slow onset of action, which makes it less suitable for anesthetic purposes. Systemic and pulmonary vascular resistance are lowered, associated with an increase in cardiac output (Bishop and Cheney 1986, Sandoval et al.1986). Common side effect are reflex tachycardia (Metha et al.1978) and an increase in pulmonary shunting (Bishop and Cheney 1986, Sandoval et al.1986, Seoane and Lupi-Herrera 1986).

Clonidine is a specific alpha $a_{2}$-adrenergic agonist, reducing centrally mediated sympathetic outflow. It causes a decrease in systemic vascular resistance, cardiac output and heart rate (Ghignone et al.1986, Pettinger 1975, Niarchos 1978). Its main disadvantages are the rather unpredict- 
able mode and duration of action, and a well known rebound hypertension when treatment is abruptly stopped (O'Connor 1981).

Among the calcium entry blockers the antihypertensive activity of nifedipine has been studied best (Van Wezel et al.1986, Franklin et al.1986). It causes arterial vasodilatation (Hess and Meyer 1986) and a decrease in coronary arteriolar resistance. The main side effects are reflex tachycardia and an increase in intrapulmonary shunting (Casthely et al.1985).

Labetolol has both al pha- and beta-adrenergic receptor blocking properties (Richards 1976, Farmer et al.1972, Morel et al.1982). It reduces arterial blood pressure by reducing systemic vascular resistance without reflex increases in heart rate. Predictable side effects are bradycardia, bronchoconstriction and decreased stroke volume (Brown et al.1977). The reduction in both heart rate and stroke volume leads to a decrease in cardiac output (Kaulman 1979). Its relatively long duration of action (418h) implies careful monitoring of blood volume because, due to the beta-adrenergic receptor blockade, compensatory mechanisms against hypovolemia may be attenuated.

Adenosine and adenine nucleotides possess vasodilator properties and have been recently studied to treat hypertension or to induce controlled hypotension (Bloor et al.1985, Torsell et al.1986, Sollevi et al.1984). They mainly cause arteriolar dilatation with a slight increase in cardiac output, but without reflex tachycardia, implicating an increase in stroke volume (Bloor et al.1985, Newberg et al.1985, Lagerkranser et al.1984, Van Aken et al.1984a). Some authors have reported a decrease in heart rate at high dose levels (Fukunaga et al.1981). The main side effect is vasoconstriction of the renal arteries (Kassel et al.1983).

Recently urapidil was introduced as antihypertensive agent (Lehmann and Heimig 1985, Puchstein et al.1984, Williams et al.1985). This compound shows alpha - and weak beta ${ }_{1}$-adrenergic receptor blocking properties and causes a decrease in systemic and pulmonary vascular resistance without reflex tachycardia. It also displays a significant centrally mediated hypotensive activity (Van Zwieten et al.1985).

From this brief survey of the mode of action of the vasodilating agents commonly used in the treatment of hypertension during and after cardiac surgery it can be concluded that there is a need for compounds with comparable efficacy, a short duration of action, a non-toxic profile, but devoid of the side effects described. In earlier studies in patients with essential hypertension ketanserin, a specific $S_{2}$-serotonergic receptor antagonist with alpha, -adrenergic receptor blocking properties, was found to be an effective antihypertensive agent, devoid of reflex tachycardia (De Cree et al.1981 c). It was considered to be appropiate to evaluate the efficacy of ketanserin in the treatment of hypertension during and following cardiac 
surgery, especially since previous reports indicated that serotonin may be released during cardiac surgery (Replogle et al.1962, llicin et al.1972, Sarajas et al.1959).

\subsection{Serotonin}

Serotonin (fig. 1.3.1) was discovered by Rapport, Green and Page (1948), and found to be present in chromaffin cells in the gastro-intestinal tract (Erspamer and Asero 1952), platelets, the pineal glands, and the central and peripheral nervous system (Garratini and Valzelli 1965). It is synthesized from tryptophan and metabolized to 5-hydroxyindolaceticacid (5HIAA) in the liver (Drapanas and McDonald 1963). The remaining free fraction of serotonin is rapidly taken up in the endothelial cells of capillaries and small vessels, especially in the lung (Gillis and Pitt 1982, Axelrod and Inscoe 1963).

Fig.1.3.1. Chemical and tridimensional crystal structure of serotonin.

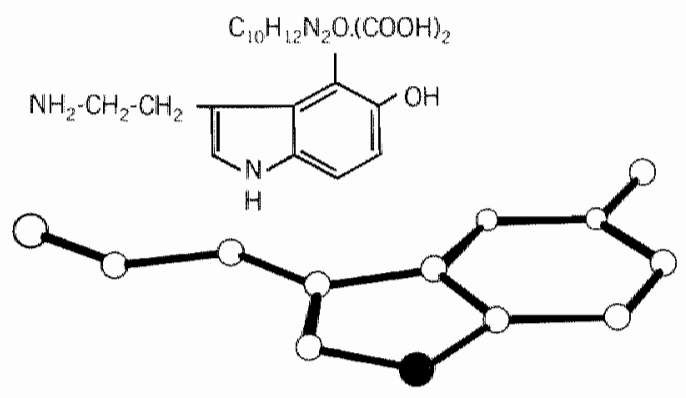

When the uptake function of the lung is diminished, like in hypertension (Vanhoutte et al.1983a), embolization (Rosoff et al.1971) and endotoxic shock (Stein and Thomas 1967), substantial increases in arterial plasma levels of serotonin are observed.

It has been reported that platelets are activated and damaged during cardiopulmonary bypass mainly due to suction (Boonstra et al.1985, De Jong et al.1980), but also as a result of blood-gas interaction in the oxygenator and contact of blood with artificial surfaces in the extracorporeal circuit (Van den Dungen et al.1982, Schmid-Schonbein 1979, Bick et al.1976, Eika 1972, Anderson et al.1978, Brown et al.1975, Barrer and Ellison 1977, Friedman et al.1970, Mohr et al.1986). Platelet aggregation is also induced by heparin (Heiden et al.1977, Eika 1972, Bell et al.1976, Wurzinger et al.1979, Thomson et al.1973, Zucker 1974, Abela et 
al.1986) and protamine (Eika 1972, Velders et al.1980, Ellison et al.1978). When platelets are activated serotonin is released from the granules causing platelet aggregation and shape changes (De Clerck and Herman 1983). This process is regulated by a surface membrane $\mathrm{S}_{2}$-serotonergic receptor, in both animals and man (De Clerck et al.1984b). Apart from the release from platelets serotonin may originate from tissues around the ascending aorta and the main left coronary artery, as has been suggested by James et al.(1975), who suggested the presence of a so-called cardiogenic hypertensive reflex. In a previous study the suggestion was made that cardiopulmonary bypass alters the process of serotonin and noradrenaline extraction by human lungs (Gillis et al.1972).

In a variety of studies serotonin was found to be involved in the central and peripheral regulation of blood pressure. For example, the intracerebral administration of serotonin produces an increase in arterial blood pressure (Kuhn et al.1980), mediated by enhanced sympathetic activity. This pressor response mainly originates from the anterior part of the hypothalamus (Robinson 1982, Smits and Struycker-Boudier 1976, Wolf et al.1981). Serotonergic neurons are also involved in the transmission of baroreflex activity, impairing vagal responses (Head and Korner 1982).

Serotonin causes contraction of most isolated arteries and veins, but differences in sensitivity have been reported (Van Nueten et al.1981 b, Feniuk et al.1983). Serotonin is a potent direct vasoconstrictor of coronary, cerebral, umbilical and pulmonary arteries (Cohen et al.1983b, Van Nueten et al.1981a,1983a, 1983c, Bentley and Henry 1981). This effect is mediated by $\mathrm{S}_{2}$-serotonergic receptors, but in a number of cutaneous arteries and in certain veins serotonin interacts with alpha-adrenergic receptors (Curro et al.1978, Leysen 1983, Van Nueten et al.1986). Serotonin also potentiates the vasoconstrictive response to angiotensin $\mathrm{I}$, noradrenaline, prostaglandin $F 2 \alpha_{1}$ thromboxane $A_{2}$ and fibrin degradation products (FDP) (Van Nueten et al.1982,1983a, Forster et al.1980, Mullane et al.1982). On the other hand serotonin causes relaxation of arterioles in the splanchnic, coronary and cerebral vascular beds (Oxdemir et al.1972), and veins (Van Nueten et al.1983a, Cohen et al.1983b). It is postulated that these effects are mediated by $S_{1}$-serotonergic receptors (Cohen et al.1983a,1983b, Houston et al.1984, Van Nueten et al.1981a), located in the endothelial cells and adrenergic nerve endings (Tuncer et al.1985, Van Nueten et al.1981a, Vanhoutte 1983b). This action is likely to be mediated by the release of endothelium-derived relaxing factors (EDRF)(Cohen et al.1983a,1983b). In this way a balance exists between the $S_{2}$-serotonergic receptor mediated vasoconstricting effect and the $S_{1}$-serotonergic receptor mediated, endothelium dependent, relaxing effect of serotonin. Serotonin has also been reported to be involved in the platelet mediated in- 
crease in vascular permeability (De Clerck et al.1984a,1984C).

\subsection{The aim of the thesis}

It was the aim of the present thesis to investigate:

- the efficacy of ketanserin to prevent systemic arterial hypertension and the effect of the compound on the humoral responses during and following coronary artery bypass surgery (chapter 4)

- the efficacy of ketanserin to treat postoperative hypertension following coronary artery bypass surgery (chapters 5 and 6)

- the differences in systemic and pulmonary hemodynamic responses between ketanserin and sodium nitroprusside in the treatment of postoperative hypertension following coronary artery bypass surgery (chapter 7)

- the differences between ketanserin and sodium nitroprusside in the treatment of pulmonary hypertension following valvular surgery (chapter 8)

- the underlying mechanism of the blood pressure lowering effect of ketanserin in man (chapter 9)

- the differences in peripheral vascular effects between ketanserin and nifedipine during cardiopulmonary bypass (chapter 10)

These chapters are preceded by a brief survey of the pharmacology of ketanserin (chapter 2) as well as a description of the anesthetic and surgical techniques used, and the postoperative management (chapter 3). The thesis ends with a general discussion of the findings in the various studies (chapter 11). 


\section{Chapter 2}

The pharmacology of ketanserin 


\section{The pharmacology of ketanserin}

Ketanserin is a quinazoline-derivative (fig. 2.1), which selectively blocks $S_{2}$ serotonergic receptors. The compound is devoid of serotonin agonistic properties, in contrast with for example methylsergide (Van Nueten 1981a,1983b, Leysen et al.1981). In higher concentrations ketanserin also binds to alpha, -adrenergic and $\mathrm{H}_{1}$-histaminergic receptors (Leysen et al.1981,1982).

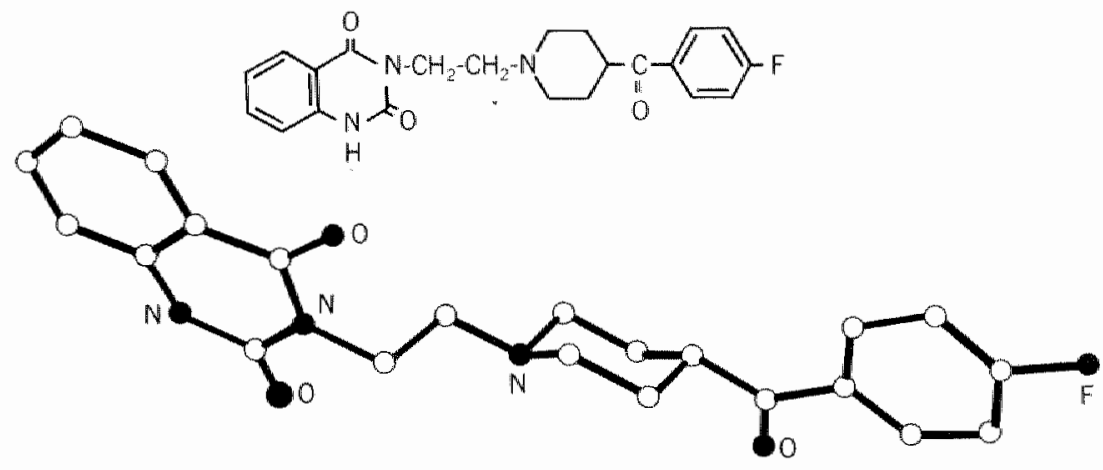

Pharmacokinetic studies performed after an intravenous injection of $10 \mathrm{mg}$, revealed that the elimination of ketanserin could be described by an open three compartment model. Total clearance was found to be $0.39 \mathrm{l} / \mathrm{kg} / \mathrm{h}$ and the volume of distribution $3.3 \mathrm{l} / \mathrm{kg}$. Terminal half-life was calculated to be $15.6 \mathrm{~h}$. After an oral administration of $20 \mathrm{mg}$ terminal half-life was found to be $18.5 \mathrm{~h}$ and the bioavailability $51 \%$ (Reimann et al.1983b, Trenk et al.1983, Heykants et al.1986).

Ketanserin is almost exclusively metabolized in the liver, the metabolites being excreted in the urine (68\%) and the faeces (24\%) (Meuldermans et al. 1984). In elderly hypertensive patients (De Cree et al.1985), the bioavialability of orally administered ketanserin is higher due to reduced hepatic elimination. In patients with renal insufficiency adaption of the doses is not necessary because only $0.7 \%$ of the parent compound is excreted in the urine and the metabolites, mainly ketanserin-ol, have negligible pharmacological activity (Heykants et al.1986).

With respect to its effect on arteries ketanserin inhibits $S_{2}$-serotonergic receptor mediated contractions of the caudal artery in the rat, the femoral and pulmonary arteries in the rabbit, the basilar, internal carotid, coronary 
and gastrosplenic arteries in the dog, and the coronary arteries in cattle (Van Nueten et al.1982, Kaumann 1983, Frenken and Kaumann 1984, Brazenor and Angus 1982).

Ketanserin also blocks the $S_{2}$-serotonergic receptor mediated contratractions of large veins in dogs and rats (Van Nueten et al. 1982, Cohen et al.1981), Ketanserin inhibits the $S_{2}$-serotonergic receptor mediated contractions of isolated blood vessels, induced by serotonin released from aggregating platelets (Cohen et al.1983a, Vanhoutte 1983b, Van Nueten 1983a). It does not prevent endothelium dependent $S_{1}$-serotonergic receptor mediated relaxation induced by serotonin or aggregating platelets (Cohen et al.1983a,1983b).

In concentrations 6-90 times higher than those required to inhibit $\mathrm{S}_{2}$ serotonergic receptor mediated effects ketanserin inhibits contractions induced by noradrenaline and histamine in isolated blood vessels from various species, including rat, rabbit, dog and man (Van Nueten et al.1982,1981b,1981c). The amplifying effect of serotonin on various agents like noradrenaline, histamine, angiotensin and prostaglandin $F_{2} \alpha$ is inhibited by ketanserin, without depressing the contractile response to the administration of the respective agonists (Van Nueten et al.1982). In vitro ketanserin prevents the $\mathrm{S}_{2}$-serotonergic receptor mediated aggregation of blood platelets induced by serotonin in platelet rich plasma of rat, cat and man (De Clerck et al.1982a,1982b). Under these circumstances ketanserin prevents the amplifying effect of serotonin on the aggregation of platelets, as induced by noradrenaline, ADP or collagen (Bevan and Heptinstall 1983).

In normotensive rats at low doses ketanserin antagonizes the pressor effect of serotonin and at higher doses also blocks the pressor effects of noradrenaline and phenylephrine (Kalkman et al.1982. Fozard 1982 , Persson et al.1982). In conscious, anesthesized, spontaneously hypertensive rats and other species ketanserin lowers systolic and diastolic blood pressure, which was attributed to the alpha - $_{1}$ adrenergic receptor blocking properties of the compound (Kalkman et al.1982, Fozard 1982, Petterson et al.1985b, Nelson et al.1984, Bolt and Saxena 1985).

In a study on closed-chest dogs ketanserin blocked the serotonin induced pulmonary hypertension and bronchoconstriction ( Van de Water et al.1985).

In man ketanserin has been mainly studied with respect to its blood pressure lowering effects (Vanhoutte et al.1983a, De Cree et al.1981 c). In patients with essential hypertension, intravenously and orally administered ketanserin decreases blood pressure, without causing reflex tachycardia (De Cree et al.1981a,1981b, Wenting et al.1982a,1982b, Wing et al.1984, McGourty et al.1984, Murphy et al.1985). 
Ketanserin has not only been evaluated in essential hypertension but also in other forms of hypertension, like preeclamptic hypertension (Weiner et al.1984a,1984b,), per- and postoperative hypertension (Nalda et al.1985, Anger et al.1985, Rucquoi et al.1985, Griffith and Whitwam 1986a,1986b, Cashman et al.1986), and neurogenic hypertension (Van Aken et al.1984b, Thomson et al.1984) and appeared to be effective in approximately $75 \%$ of the patients. Recently ketanserin was reported to be effective in the perioperative control of blood pressure in patients with carcinoid syndrome (Casthely et al.1986, Houghton and Carte 1986).

Among the mechanisms underlying the blood pressure lowering effect of ketanserin several possibilities have been postulated: merely alpha adrenergic receptor blocking activity, (Reimann and Frohlich 1983a, Petterson et al.1985b, Zabludowski et al.1985, Gasic et al.1985), mainly $\mathrm{S}_{2}-$ serotonergic blockade (Wenting et al.1984), centrally mediated inhibition of sympathetic vascular tone (Phillips et al.1985, McCall and Schuette 1984, Petterson et al.1984, Lakoski et al.1985, Mylechrane et al.1985, Copeland and Bentley 1985), and a miscellaneous mode of action, incorporating these mechanisms (Vanhoutte 1985). It has been suggested that an interaction betweer blockade of $S_{2}$-serotonergic and alpha $a_{1}$-adrenergic receptors plays a role in the antihypertensive action of ketanserin (Van Nueten et al.1986).

Studies on the effect of ketanserin on myocardial contractility show that the compound does not impair myocardial function and even might be beneficial, since it prevents arrhythmias in ischemic conditions (Saman et al.1985). Ketanserin does not affect heart rate (Walker et al.1984). The latter phenomenon might indicate that ketanserin blocks the sympathetic outflow of catecholamines by its inhibitory action on central alpha ${ }_{4}^{-}$ adrenergic receptors.

The effect of ketanserin on the pulmonary circulation includes a reduction of pulmonary vascular resistance, particularly in conditions like pulmonary embolization, endotoxic shock and adult respiratory distress syndrome (Meuleman et al.1983, Huval et al.1983, Vincent et al.1984, Koyama et al.1985, Hechtman and Sherpo 1984, Breuer et al.1986).

In normotensive man the effects of ketanserin on the humoral system include an increase in renin activity and angiotensin $\|-\|$ evels. The compound has rninimal effect on plasma aldosterone, cortisol and noradrenaline levels (Zoccali et al.1983, Fagard et al.1984b, Reimann et al.1985). In patients with essential hypertension ketanserin causes a slight rise in plasma levels of aldosterone and noradrenaline and a decrease in renin activity and plasma levels of angiotensin II (Zabludowski et al.1984, Fagard et al.1984a), presumably due to increased renal cortical blood flow. The reported side effects after intravenous injection are sleepiness, light- 
headedness and hypotension (Amery et al.1985, Murphy et al.1985, Jennings and Opie 1987). 
Chapter 3

Anesthetic and surgical techniques, and postoperative management 


\subsection{Anesthetic technique and monitoring}

All patients undergoing coronary artery bypass surgery included in the studies on systemic arterial hypertension had a normal left ventricular function, as evaluated by ejection fraction, left ventricular end-diastolic pressure and wall motion descriptions at preoperative left ventricular angiography. All patients had chronic therapy with beta-blocking agents (propanolol, metoprolol), calcium entry blockers (nifedipine) and nitrates, received their medecation up to $6-8$ hrs before induction of anesthesia. None of the patients had concomitant renal, hepatic or pulmonary disease or had received anticoagulant medication preoperatively.

The patients who suffered from valvular heart disease also had their cardiac medication continued until 6-8 hrs before surgery, but long-acting coumadines were stopped 3-4 days preoperatively and replaced by intravenous heparin.

The patients were premedicated with scopolamine $0.005 \mathrm{mg} / \mathrm{kg}$ and morphine $0.15 \mathrm{mg} / \mathrm{kg}$ between 45 and 60 minutes before induction of anesthesia. In the operating room an intravenous (peripheral) and intra-arterial (radial artery) catheter were inserted, E.C.G. electrodes were placed (lead II and V5), and induction was started by means of fentanyl $30 \mu \mathrm{g} / \mathrm{kg}$, pancuronium bromide $0.1 \mathrm{mg} / \mathrm{kg}$ and etomidate $0.2 \mathrm{mg} / \mathrm{kg}$. During the pre-bypass procedure the lungs of the patients were ventilated with $100 \%$ oxygen in the following studies: the comparison between nitroprusside and ketanserin in the treatment of postoperative hypertension following coronary artery bypass grafting (CABG) and in the treatment of pulmonary hypertension following valvular surgery. They were ventilated with $50 \% \mathrm{O}_{2} / 50 \% \mathrm{~N}_{2} \mathrm{O}$ in the remaining studies. However, in the early post-bypass period the patients were ventilated with $100 \%$ oxygen in all the studies. Anesthesia was maintained by means of the intermittent administration of fentanyl (maximum $75 \mu \mathrm{g} / \mathrm{kg}$ ), pancuronium (maximum $0.2 \mathrm{mg} / \mathrm{kg}$ ) and nidazolam $(0.15 \mathrm{mg} / \mathrm{kg}$ ). After endotracheal intubationa nasogastric tube was inserted and then nasopharyngeal and rectal temperature probes were placed. A Swan Ganz thermodilution pulmonary artery catheter (Edwards) (Swan et al.1970) was inserted through an internal jugular or a subclavian vein via an introducer system (Argon) to measure central venous pressure (CVP), pulmonary artery pressure (PAP), pulmonary capillary wedge pressure (PCWP). Cardiac output (CO) was determined by means of the thermodilution method (Edwards). All measurements were made in triplicate during the same phase of respiration. Systemic (SVR) and pulmonary (PVR) vascular resistance were calculated by means of standard equations. In the studies described in chapters 4 and 8 the pulmonary artery catheter was inserted under local anesthe- 
sia before induction of general anesthesia in order to obtain control values in the awake patient (Damen and Bolton 1986). In all patients a catheter was inserted into the bladder after induction of anesthesia.

During the pre-bypass period $10 \mathrm{~m} / \mathrm{kg}$ Ringer's lactate with $5 \%$ glucose was infused in order to maintain a CVP between 5 and $8 \mathrm{mmHg}$ and a PCWP between 8 and $10 \mathrm{mmHg}$. If the colloid osmotic pressure (COD), measured with a membrane-transducer oncometer, was lower than $18 \mathrm{mmHg}, 100 \mathrm{ml}$ albumin $20 \%$ solution was slowly administered.

The anesthesia technique was associated with a $10-15 \%$ decrease of mean arterial blood pressure during induction and an elevation of systolic arterial blood pressure up to $130 \mathrm{mmHg}$ during intubation, a level maintained during the prebypass period. If this intravenouls, balanced anesthesia technique (Milocco et al.1985) failed to prevent hypertension, vasodilatation with a continuous infusion of nitroglycerin was applied (Stengert et al.1978). Inhalation anesthetics, specifically halothane, were avoided to prevent dysrhythmias in the presence of elevated levels of catecholamines (Spiss et al.1984, Brown and Gandolfi 1987, Halsey 1987, Sorensen et al.1986, Turner et al.1986, Hess et al.1983). In addition recent data suggest that isoflurane may cause a "steal phenomenon" in patients with ischemic heart disease (Reiz and Ostman 1985, Gelman et al. 1984).

The fentanyl dose used ( $30 \mu \mathrm{g} / \mathrm{kg}$ at induction, augmented to $75 \mu \mathrm{g} /$ $\mathrm{kg}$ at sternotomy) is considered to be a moderate analgesic dosage (Bailey et al.1985), but in combination with hypnotic and relaxant agents it has been reported to be sufficient to overcome stressful events in the prebypass period (Murphy et al.1983). We did not choose for a mono anesthetic high dose fentanyl-technique $(100 \mu \mathrm{g} / \mathrm{kg})$ in the coronary artery bypass surgery patients (Yrjola 1983, Murkin et al.1985, Moffitt et al.1984, Bazaral et al.1985), because it excessively prolongs extubation time postoperatively and because of other reported complications like peroperative awareness, postoperative muscle rigidity and respiratory depression (Hardy et al.1983, Sanford et al.1986, Sebel et al.1982a, Peters et al.1979). In the group of patients undergoing surgery for valvular disease (chapter 8$)$, a high dose fentanyl technique $(100 \mu / \mathrm{kg}$ ) was prefered because of the favorable influence on the cardiovascular system of these high-risk patients during induction (Bovill et al. 1984a,1984b, Wynands et al.1983), the reduction of the stress response during surgery and because a longer duration of mechanical ventilation postoperatively is required in these patients when compared to patients undergoing coronary artery bypass surgery (Howie et al.1985).

Etomidate was administered as hypnotic agent because of its minimal effects on the cardiowascular system (Reneman et al.1974, Xhonneux et al.1974, Spiss et al.1984, Nimmo and Miller 1983, Giese et al.1985, 
McCollum and Dundee 1986, Sear 1987). Although recent reports suggest a depression of the adrenal-cortical system (Metha et al.1985, Wanscher et al.1985, Wagner and White 1984, Fragen et al.1984, Moore et al.1985a) during the administration of etomidate, in our department the drug is considered to be the best possible choice for these high-risk patients.

Pancuronium bromide as non-depolarizing muscle relaxant may cause tachycardia, mainly because of its vagolytic properties (Saxena and Bonta 1970), but possibly also by facilitating noradrenaline release (Bowman 1980). In the presence of fentanyl, with its vagomimetic properties, tachycardia is seldom seen, particulary in patients who received beta-blocking agents preoperatively (Crul 1982, Miller 1982, Slogoff et al.1978).

Midazolam $(0.15 \mathrm{mg} / \mathrm{kg})$ was administered $10-15 \mathrm{~min}$ after the etomidate dose during maintenance of anesthesia because of its minimal influence on the cardiovascular system and its advantages over diazepam, particulary with respect to the difference in metabolism (Marty et al.1986a,1986b, Greenblatt et al.1984, Reves et al.1985).

When the pericardium was opened heparin $3 \mathrm{mg} / \mathrm{kg}$ was injected through the introducer side-port. When the activated clotting time (ACT), which indicates the degree of heparinization of the patient, was longer than 400 sec the ascending aorta was cannulated. When the patient was weaned from cardiopulmonary bypass and no serious bleeding was present, protamine sulphate was slowly injected intravenously in a dose equal to the heparin dose. The residual priming solution from the extra-corporeal circuit was infused postoperatively, together with a slow infusion of $100 \mathrm{mg}$ of protamine sulphate for every $1000 \mathrm{ml}$ prime. In this period the activated clotting time was considered to be normal when it remained below $140 \mathrm{sec}$.

Just before the start of cardiopulmonary bypass etomidate $0.2 \mathrm{mg} / \mathrm{kg}$ was injected intravenously, because the very first episode of cardiopulmonary bypass represents the most dangerous period with respect to the cerebral function of the patient and etomidate might act as a cerebral protective agent (Wauquier et al.1981, Hempelman et al.1982, Newberg Milde and Milde 1986), comparable with the cerebral protection by barbiturates (Nussmeier ett al.1986).

Occasionally pancuronium bromide and fentanyl were injected during cardiopulmonary bypass in incremental doses, especially when this period lasted longer than 60 minutes, to stabilize the patient particularly during the rewarming phase and to guarantee adequate muscle relaxation during the often required defibrillation before weaning from cardiopulmonary bypass. In most cases midazolam $0.1 \mathrm{mg} / \mathrm{kg}$ was administered after the end of the surgical procedure just before leaving the operating 
room (Lowry et al.1985), to ensure adequate sedation before installation in the ICU.

\subsection{Surgical technique}

The surgical technique in the patients undergoing coronary artery bypass surgery was standardized. After heparinization, an arterial and venous cannula were inserted into the aorta and the right atrium, respectively, whereafter cardiopulmonary bypass was slowly started. A venting system was inserted into the aortic root and connected to a roller pump to evacuate blood from the left ventricle. The patient was first cooled to a nasopharyngeal temperature of $32^{\circ} \mathrm{C}$ and the definitive locations for the venous grafts on the coronary arteries were determined. The aorta was cross-clamped followed by the infusion of $10 \mathrm{ml} / \mathrm{kg}$ of a hyperkalemic cardioplegic solution at $4^{\circ} \mathrm{C}$ into the aortic root. The patient was then further cooled to approximately $28^{\circ} \mathrm{C}$. The heart was simultaneously cooled externally by flushing the pericardiall cavity with 2 litres of cold saline $\left(4^{\circ} \mathrm{C}\right)$.

First the distal anastomoses were made whereafter the aorta was declamped. Generally so-called jump grafts were constructed, which means that only one or two proximal anastomoses had to be made. When the patient was rewarmed to $36.5^{\circ} \mathrm{C}$ nasopharyngeally and $34.5^{\circ} \mathrm{C}$ rectally, weaning from cardiopulmonary bypass was started, followed by decannulation when the hemodynamic status of the patient was considered to be adequate. The sternum was closed by means of sternal wires. Usually one mediastinal drain was used, except when the pleura was accidentally opened, in which case a pleural drain was also inserted.

In valvular surgery two venous cannulas were inserted through the right atrium into the superior and inferior caval vein respectively, and the left ventricle was temporarily vented through a cannula, inserted via a pulmonary vein. In patients with aortic insufficiency, the cardioplegic solution was administered by means of two separate cannulas in the ostia of the left and right coronary arteries. External temporary pacing wires were sutured to the epicardium before weaning from cardiopulmonary bypass.

\subsection{Cardiopulmonary bypass technique}

Cardiopulmonary bypass was achieved by means of a heart-lung machine (Sarns) with four roller pumps. The extracorporeal circuit consisted of PVC-tubing, including a cardiotomy reservoir, and a bubble oxygenator (Harvey, Bentley) connected to a heater-cooler system (Sarns). 
The priming solution of the extracorporeal circuit consisted of $20 \mathrm{ml} /$ $\mathrm{kg}$ Ringer's lactate with $5 \%$ dextrose, $100 \mathrm{ml} \mathrm{NaHCO} 8.4 \%$ and $100 \mathrm{mlal}-$ bumin $20 \%$. If the hematocrit, measured after 5 minutes of cardiopulmonary bypass, was lower than $20 \%$, one unit of red blood cell concentrate was added. When during cardicpulmonary bypass the colloid osmotic pressure was lower than $10 \mathrm{mmHg}, 100 \mathrm{ml}$ albumin $20 \%$ was added.

The flow was calculated with the use of a flow rate computer (Sarns) and kept as close as possible to $50 \mathrm{ml} / \mathrm{kg} / \mathrm{min}$. Mean arterial pressure was adjusted between 50 and $80 \mathrm{mmHg}$ by administering either phenylephrine, an alpha-adrenergic vasoconstricting agent, to increase blood pressure, or vasodilators, like nitroglycerin, nitroprusside or chlorpromazine, to decrease blood pressure.

Anticoagulation was monitored by intermittent measurements of activated clotting time (ACT) which was kept above $400 \mathrm{sec}$. If lower heparin was administered in incremental bollus doses of $50 \mathrm{mg}$.

The temperature of the patient, measured by means of nasopharyngeal and rectal temperature probes, was kept at approximately $28^{\circ} \mathrm{C}$ nasopharyngeally. Rewarming was started just after the last distal anastomosis was completed, and terminated when the temperature had reached $36.5^{\circ} \mathrm{C}$ nasopharyngeally and $34.5^{\circ} \mathrm{C}$ rectally.

In the patients who received coronary artery bypass grafts weaning from cardiopulmonary bypass was routinely managed without the administration of inotropic agents, like dopamine or dobutamine. But in most patients calcium chloride was injected to increase temporarily myocardial contractility during weaning. In the patients undergoing valvular surgery, inotropic agents were routinelly administered during and after weaning from cardiopulmonary bypass to improve myocardial contractility. A combination of dopamine and dobutamine was used in order to improve myocardial performance as well as renal and systemic perfusion. After weaning from cardiopulmonary bypass the residual priming solution in the oxygenator was transfered to a plastic infusion bag for re-infusion during the early postoperative period.

\subsection{General postoperative management}

In the Intensive Care Unit (ICU) the patient was mechanically ventilated (Siemens Servo ventilator), keeping the $\mathrm{PaCO}_{2}$ between 35 and $45 \mathrm{mmHg}$ and the $\mathrm{PaO}_{2}$ between 80 and $150 \mathrm{mmHg}$. Positive end-expiratory pressure (PEEP) was not used routinely (Marvel et al.1986, Good et al.1979), as long as the blood gas criteria were fulfilled by means of con- 
ventional intermittent positive pressure ventilation (IPPV).

During the study periods the patients were sedated with midazolam and muscle relaxation was maintained with pancuronium or vecuronium to eliminate influences of wakening and intolerance to the endotracheal tube. Postoperatively ECG (lead II and V5), heart rate (HR), arterial blood pressure (AP), central venous pressure (CVP), pulmonary artery pressure (PAP) and pulmonary capillary wedge pressure (PCWP) were continuously monitored, and cardiac output, systemic and pulmonary vascular resistance intermittently determined.

In the patients undergoing coronary artery bypass grafting the fluid regimen consisted of $1 \mathrm{ml} / \mathrm{kg} / \mathrm{hour}$ Ringer's lactate with $5 \%$ dextrose. If the colloid osmotic pressure was lower than $18 \mathrm{mmHg}, 100 \mathrm{ml}$ albumin $20 \%$ was infused. During the first hour the infusion mainly consisted of the residual priming solution from the extracorporeal circuit. During infusion of this priming substance $100 \mathrm{mg}$ protamine/1000 ml infusion fluid was slowly administered, to neutralize the residual amount of heparin. Drainage through the chest tube was maintained at a suction pressure of $12 \mathrm{~cm} \mathrm{H}_{2} \mathrm{O}$. Blood loss was considered to be normal if less than an average of $100 \mathrm{ml} / \mathrm{hr}$ in the first three hours. If this was exceeded the patient was excluded from the study.

Diuresis was normally high in the first few hours (more than $100 \mathrm{ml} / \mathrm{h}$ ) due to the residual hemodilution, as indicated by a hematocrit between 24 and $28 \%$ when the patient entered the ICU.

A patient undergoing coronary artery bypass grafting was excluded from the study if he or she did not have a normal sinus rhythm with a heart rate between 70 and $110 / \mathrm{min}$ or developed low cardiac output during the study period which needed treatment with inotropic agents like dopamine and dobutamine.

Antibiotic prophylaxis was $15 \mathrm{mg} / \mathrm{kg}$ cefamandole given 6 hourly for 24 hours.

In the patients undergoing valvular surgery, the infusion regimen was different: $1.5 \mathrm{~m} / \mathrm{kg} / \mathrm{hour}$ Ringer's lactate with $5 \%$ dextrose was administered after the infusion of the residual priming solution.

In this group of patients PEEP had to be applied because of increased pulmonary water content causing diminished pulmonary function (Boldt et al.1985). Inotropic agents were necessary in all patients to increase cardiac output. This therapy consisted of dopamine, dobutamine or a combination of these agents, and was started during weaning from cardiopulmonary bypass (see section 3.3). Since dysrhythmias, including heart block, were frequently observed during the first postoperative hours following valvular surgery, temporary pacing was used in most of the patients. 
Many of the valvular patients had an abnormal clotting profile due to the preoperative use of coumadine derivates, congestive heart failure with liver insufficiency and/or prolonged periods of cardiopulmonary bypass. Fresh frozen plasma and platelet concentrate were infused when indicated by laboratory tests, i.e. activated partial thromboplastin time, prothrombine time, thrombotest and platelet count. The criteria for blood loss were the same as in the group undergoing coronary artery bypass grafting. In the patients undergoing valvular surgery the prophylactic antibiotic regimen consisted of cefamandole ( $15 \mathrm{mg} / \mathrm{kg}$ given 6 hourly) and gentamycin, both drugs given for 24 hours and the dosage of the latter drug adjusted to body weight and renal function. 


\section{Chapter 4}

\section{Ketanserin during and following coronary artery bypass grafting: hemodynamic and humoral responses}

P.J.A. van der Starre, J.E. Harinck-de Weerd, C. de Boelpaepe, F. de Clerck, R.S. Reneman.

Anesthesiology (submitted) 


\section{Introduction}

Hypertension during and following coronary artery bypass grafting (CABG) is a major clinical problem (Estafanous et al.1973, Estafanous and Tarazi 1980, Roberts et al.1977. Wallach et all.1980), since it may cause myocardial ischemia, bleeding and neurological complications (Moffitt et al.1985, Merin 1980, Slogoff and Keats 1986). Increased levels of circulating catecholamines (Roberts et al.1977, Balasarawathi et al 1978, Low et al.1986), attributed to pressor reflexes from the heart, the great vessels and the coronary arteries, and increased concentrations of renin and angiotensin (Bailey et al.1975, Taylor et al.1979) due to the use of hemodilution (Hine et al.1976) and hypothermia (Arnett and Watts 1960, Chernow et al.1983) during cardiopulmonary bypass (CPB) have been considered to contribute to the development of perioperative hypertension. Serotonin (Replogle et al.1962, James et al.1975, Swank et al.1964, llicin et al.1972), for example released during the activation and aggregation of platelets (Wenzel et al.1979), might play a role as well. Hemodynamic studies revealed that perioperative hypertension is associated with an increase in systemic vascular resistance without a significant change in cardiac performance (Kim et al.1981, Estafanous et al.1984).

The treatment of perioperative hypertension generally consists of lowering arterial blood pressure by means of vasodilating agents, like sodium nitroprusside (Kaplan and Jones 1979, Tinker and Michenfelder 1976), nitroglycerin (Gallagher et al.1986, Gerson et al.1982), hydralazine (KochWeser 1976), trimetaphan (Stinson et al.1975) and calcium entry blockers (Van Wezel et al.1986, Franklin et al.1986). Blockade of the stellate ganglion (Fouad et al.1978, Bidwai and Rogers 1979) and epidural anesthesia (Hoar et al.1976) also have been advocated. Anesthesia techniques with the use of high doses of narcotic compounds, like fentanyl (De Lange et al.1982, Sebel et al.1982) and sufentanil (Howie et al.1985. Sebel and Bovill 1982, Rosow et al.1984), have been used to prevent hypertensive responses during induction and surgery, but side-effects, like rigidity and prolonged postoperative respiratory depression, are a major concern (Sebel and Bovill 1982, Hardy et al.1983, Sanford et all 1986).

Ketanserin, a specific $\mathrm{S}_{2}$-serotonergic receptor blocking agent (Van Nueten et al.1981, Van Nueten 1983) with $\alpha_{1}$-adrenergic receptor blocking properties (Gasic et al.1985, Petterson et al.1985, Reimann and Frohlich 1983) has been used in the treatment of postoperative hypertension following CABG and appeared to be effective in lowering arterial blood pressure in the majority of the patients (Van der Starre et al.1983). In in vitro studies the compound also prevented serotonin induced aggregation of 
platelets (De Clerck and Van Nueten 1982, De Clerck et al.1982).

in the present prospective double-blind study we investigated whether a continuous infusion of ketanserin during and after CABG could modulate the pressor responses, the plasma levels of vasoactive hormones, like catecholamines, renin and angiotensin, the dose of fentanyl used and the number of nitroglycerin administrations required to treat hypertensive episodes. Since pressor reflexes may influence renal blood flow, diuresis was intermittently recorded. Plasma levels of beta-thromboglobulin "platelet factor -4 and serotonin also were measured to obtain information about possible platelet activation.

\section{Methods and materials}

The prospective double-blind study was performed in 2 groups of $12 \mathrm{pa}$ tients undergoing $\mathrm{CABG}$. The patients had a normal myocardial function and no concomitant diseases. All patients gave informed consent and the protocol was approved by the Hospital Ethics Committee Premedication consisted of $0.005 \mathrm{mg} / \mathrm{kg}$ scopolamine IM and $0.15 \mathrm{mg} / \mathrm{kg}$ morphine IM, administered 45-60 min before induction of anesthesia. After arrival in the operating room ECG monitoring was started (lead II and $V_{5}$ ), and a peripheral venous and a radial artery cannula were inserted. Before induction of anesthesia a Swan-Ganz thermodilution catheter was inserted into the pulmonary artery via an internal jugular vein. Heart rate ( $H R$, as assessed from the ECG), systolic (SBP), diastolic (DBP), and mean (MAP) arterial blood pressure, mean pulmonary artery pressure (MPAP), central venous pressure (CVP), and pulmonary capillary wedge pressure (PCWP) were measured. The pressures were measured with external transducers (Bentley). Cardiac output ( $\mathrm{CO}$ ) was determined by means of thermodilution (Edwards), using $10 \mathrm{ml}$ of saline at room temperature. The average of three measurements, made during the same phase of respiration, was taken as the actual value. Systemic (SVR) and pulmonary (PVR) vascular resistance were calculated using standard formulas. Nasopharyngeal and peripheral (skin) temperatures were continuously moritored and recorded (Philips thermistor probes). Anesthesia was induced with fentanyl $50 \mu \mathrm{g} / \mathrm{kg}$, pancuronium bromide $0.1 \mathrm{mg} / \mathrm{kg}$ and etomidate $0.2 \mathrm{mg} / \mathrm{kg}$. Midazolam $0.2 \mathrm{mg} / \mathrm{kg}$ was administered $15-20$ minutes after induction and in the early post-bypass period. The patients were ventilated with $100 \% \mathrm{O}_{2}$ during surgery and with $50 \% \mathrm{O}_{2} / 50 \%$ air in the first postoperative hours. Ventilation was adjusted to maintain a $\mathrm{PaCO}_{2}$ between 35 and $45 \mathrm{mmHg}$.

Immediately after intubation of the trachea a continuous infusion of 
either $0.1 \mathrm{mg} / \mathrm{kg} / \mathrm{hr}$ ketanserin (group $\mathrm{K}$ ) or the solvent of ketanserin (group S) was started. The patients were randomly allocated to either group. If the patient developed hypertension in the pre-bypass period during surgery (SBP higher than $130 \mathrm{mmHg}$ ), fentanyl was administered in incremental doses of $0.5 \mathrm{mg}$, up to a total dose of $75 \mu \mathrm{g} / \mathrm{kg}$. If this was not sufficient to normalize arterial blood pressure, a continuous infusion of nitrog ycerin was started. During cardiopulmonary bypass (CPB) flow rate was set at 50 to $60 \mathrm{ml} / \mathrm{kg}$ and MAP was kept between 40 and $60 \mathrm{mmHg}$. The initial priming solution of the extracorporeal circuit consisted of $20 \mathrm{ml} / \mathrm{kg}$ Ringer's lactate with $5 \%$ dextrose. If during CPB the colloid osmotic pressure (COP), as determined with a membrane-transducer oncometer (Barclay and Bennett 1987), was lower than $10 \mathrm{mmHg}, 100 \mathrm{ml}$ albumin $20 \%$ was added. None of the patients received any other blood product during and following surgery. During CPB the patients were cooled to $28-30^{\circ} \mathrm{C}$ nasopharyngeal temperature and the heart was arrested by means of a cold potassium cardioplegic solution. To prevent a prolonged period of hypotension, the infusion of ketanserin, and hence solvent, was stopped just before the initiation of CPB. The infusion was started again when MAP was higher than $50 \mathrm{mmHg}$. After termination of $\mathrm{CPB}$ and in the following postoperative period the infusion of ketanserin or solvent was continued for at least 3 hrs. When hypertension (SBP higher than $150 \mathrm{mmHg}$ ) developed, a nitroglycerin infusion was started. The above mentioned variables were recorded and calculated before induction (1, control values), before thoracic skin incision (2), during sternotomy (3). just after the administration of heparin (4), 15 (5) and $45 \mathrm{~min}$ (6) after the start of $\mathrm{CPB}$, at the end of $\mathrm{CPB}$ (7), 15 min after termination of CPB (8), at arrival in the ICU (9), and 60 (10), 120 (11) and $180 \mathrm{~min}$ (12) after arrival in the ICU. Arterial blood samples for determination of the plasma concentrations of circulating adrenaline, noradrenaline, dopamine, plasma renin and angiotensin II were obtained before induction (1), before sternal skin incision (2), during sternotomy (3), 15 (5) and 45 min (7) after the start of $\mathrm{CPB}$, irnmediately after termination of $\mathrm{CPB}(8)$ and 120 min after arrival in the ICU (11). Plasma levels of platelet factor-4, beta-thromboglubin, plasma serotonin and platelet-bound serotonin were determined and platelets were counted before induction (1), after termination of $\mathrm{CPB}(8)$, and 120 (11) and $180 \mathrm{~min}$ (12) after arrival in the ICU. The dose of fentanyl administered in the pre-bypass period and the necessity to infuse nitroglycerin in the pre-bypass and postoperative ICU-periods were recorded. Pre-, per- and post-bypass diuresis was also recorded.

Radioimmunoassay techniques were used to determine plasma levels of adrenaline, noradrenaline, dopamine, renin, angiotensin II (De Leeuw et 
al.1983), and platelet factor-4 and beta-thromboglubin plasma levels (De Clerck et al.1982). Plasma-serotonin and platelet-bound serotonin were determined by fluorimetric methods as described by Drummond (Drummond and Gordon 1974). The total number of platelets was determined with a Coulter-Counter technique.

Changes within the groups were evaluated for statistical significance with the use of the Wilcoxon signed-rank test, two tailed probability, and differences between the groups by applying the Mann-Whitney U-test. Differences in the number of nitroglycerin administrations in the pre-bypass and postoperative period, and the demographic data were evaluated by Fisher's exact test. Differences were considered to be significant in case of a probability value $p<0.05$. The data are presented as mean $\pm S E M$.

\section{Results}

There were no significant differences between the groups with respect to age, sex, weight, number of bypass grafts, aortic clamp time and CPBtime (table 1). No patient in either group needed inotropic support during the study period.

Table 4.1. Demographic data of the patients in both groups

Ketanserin

12

number

age (yrs)

$\operatorname{sex}(M / F)$

weight (kg)

AoC (min)

$\mathrm{CPB}(\min )$

$\mathrm{ACB}(n)$

\section{Solvent}

12

$57 \pm 12$

$12 / 0$

$80 \pm 1.9$

$48 \pm 5.3$

$73 \pm 6.1$

$5 \pm 0.2$

Values are presented as mean $\pm \mathrm{SEM}$.

$\mathrm{AoC}=$ Aortic clamp time $\mathrm{CPB}=\mathrm{Cardiopulmonary}$ bypass time; $\mathrm{ACB}=$ number of venous bypass grafts

In both groups SBP (fig 1) significantly decreased after induction of anesthesia, increased to the pre-induction value during sternotomy and in group K significantly decreased again in the period preceding CPB. Imme- 
Fig. 4.1 .
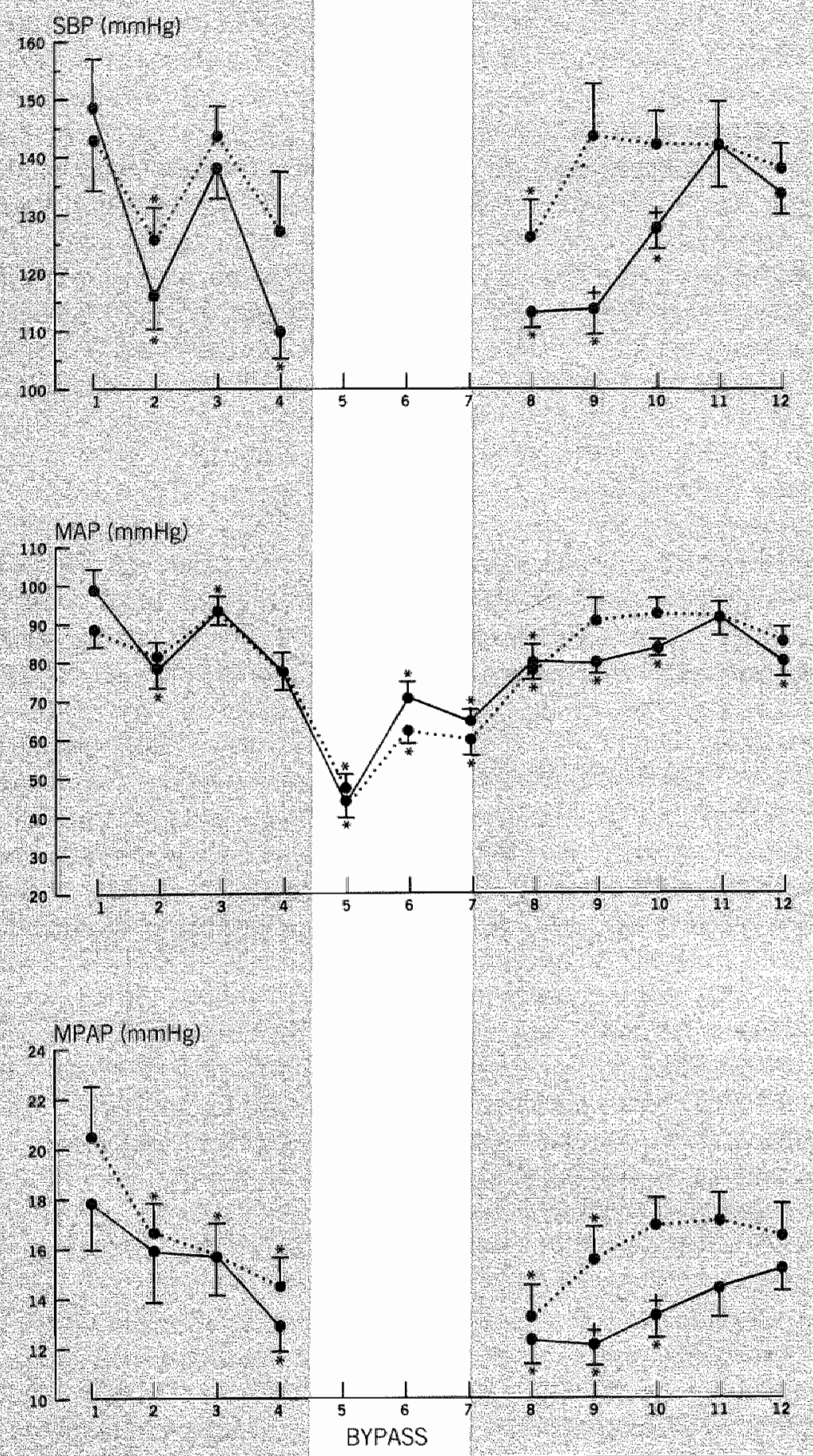
diately following CPB, SBP was significantly lower than the control value (before induction) in both groups. In the ICU SBP remained lower than the control value in group $K$ till $60 \mathrm{~min}$.

In both groups DBP (not depicted) significantly decreased after induction of anesthesia, and increased to the pre-induction value in the remaining pre-bypass period. After CPB DBP values were similar to the pre-induction values in both groups. Between the groups there were no significant differences in DBP during the complete study period.

in both groups MAP (fig 1) followed the same pattern as SBP in the prebypass and in the early post-bypass period. In both groups MAP was signi* ficantly lower during CPB than in the control period. During the first hour im the ICU MAP was significantly lower in group $K$ than in group $S$.

In group S MPAP (fig 1) decreased following induction of anesthesia and remained lower than the control value until the start of CPB. In group $K$ MPAP was lower than the control value only just before CPB. After CPB MPAP was lower than in the control period in both groups. In group $K$ the decrease in MPAP was more pronounced and MPAP remained lower for a longer period of time. During the first hour in the ICU MPAP was significantly lower in group $\mathrm{K}$ than in group $\mathrm{S}$.

In group S HR (fig 2) was significantly higher than in the control period at sternotomy, in the remaining pre-bypass period, in the whole post-bypass period and in the ICU. In group K HR was significantly higher than in the control period during the whole post-bypass and ICU-periods. At sternotomy and from 60 min after arrival in the ICU HR was significantly lower in group $K$ than in group $S$.

In group SCO (fig 2) was significantly lower than in the control period at sternotomy, in the remaining pre-bypass period and in the early post-by-

Fig.4.1.

Systolic (SBP) and mean (MAP) arterial pressule, and mean pulmonary artery pressure (MPAP) in the solvent (....) and ketanserin (-) groups during and following surgery (mean \pm SEM).

$1=$ betore induction (comtrol value); 2 - betore stermal skin incision; 3 wim during sternotomy: $4=$ after the administration of heparin: $5=$ at 15 min on $C P B ; 6=$ at 45 min on $\mathrm{CPB} ; 7=$ at the end of $\mathrm{CPB} ; 8=15$ min after $\mathrm{CPB} ; 9=$ at arriwal in the $1 \mathrm{CU} ; 10=60$ min after arrival in $1 \mathrm{CU}, 11=120 \mathrm{~min}$ after arrwal in $1 \mathrm{CU} ; 12 \mathrm{~m} 180 \mathrm{~min}$ after arrival in ICU.

BYPASS = cardiopulmonary bypass.

* = significantly different trom control value $(p<0.05)$

$+=$ significant difference between the groups $(p<0.05$ ) 
Fig. 42

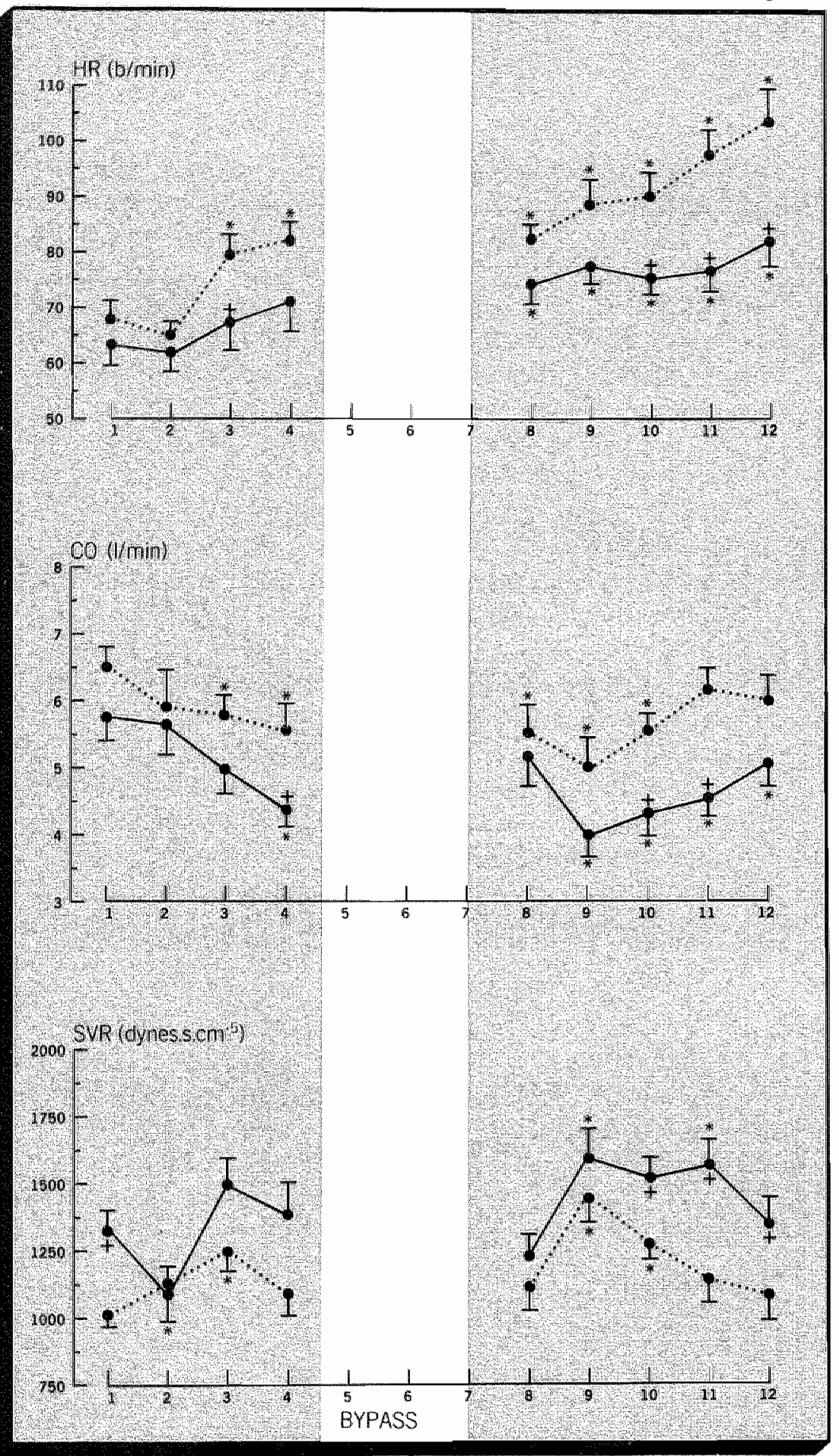


pass period until 60 min after arrival in the ICU. In group K CO was lower than in the control period immediately before $\mathrm{CPB}$ and after $\mathrm{CPB}$ from the moment of arrival in the ICU. In group KCO was significanty lower than in group S immediately before $\mathrm{CPB}$ and 60 and 120 min after arrival in the ICU.

In group S SVR (fig 2) was significantly higher than in the control period after induction of anesthesia, at sternotomy and during the first $60 \mathrm{~min}$ in the ICU. In group K SVR was higher than in the control period at sternotomy, at arrival and 120 min after arrival in the ICU. SVR was significantly higher in group $K$ than in group $S$ before induction of anesthesia and from $60 \mathrm{~min}$ after arrival in the ICU.

The nasopharyngeal temperature (fig 3) changed equally in both groups during and following the investigation, but the peripheral (skin) temperature (fig 3 ) was significantly higher in group $\mathrm{K}$ than in group $\mathrm{S}$ from the end of CPB up to 120 min after arrival in the ICU. In group S skin temperature was significantly lower during the post-bypass period, as compared with the control value.

Catecholamine-levels (fig 4) increased significantly in both groups from the initiation of $\mathrm{CPB}$ and remained higher than the control value during the residual study period. In group $K$ the adrenaline-levels were significantly lower than in group S 180 min after arrival in the ICU. The plasma levels of noradrenaline tended to be lower 120 and 180 min after arrival in the ICU in group $K$, but this difference did not reach the level of significance. The changes in dopamine-levels (fig 4) were similar to those observed in the other catecholamine-levels and were not significantly different in both groups. The renin- and angiotensin II-levels (fig 4) significantly increased in both groups from the moment of sternotomy and remained significantly elevated during the complete study period. The renin and angiotensin II-levels tended to be lower in group $K$, but the difference only reached the level of significance $180 \mathrm{~min}$ after arrival in the ICU. In both groups the plasma levels of beta-thromboglobulin and platelet factor- 4 were significantly higher after termination of CPB and in the postoperative period as compared with the control values. Plasma-serotonin and plate-

\section{Fig. 4.2.}

Heart rate $(H R)$ cardiac output (CO) and systemic vascular resistance (SVR) in the solvent $(\ldots .$.$) and ketanserin (-) groups during and following surgery (mean \pm$ SEM). For explanation of recording moments and abbreviations see Fig. 4.1.

* = significantly different from control value $(p<0.05)$

$+=$ significant difference between the groups $(p<0.05)$ 
Fig. 4.3

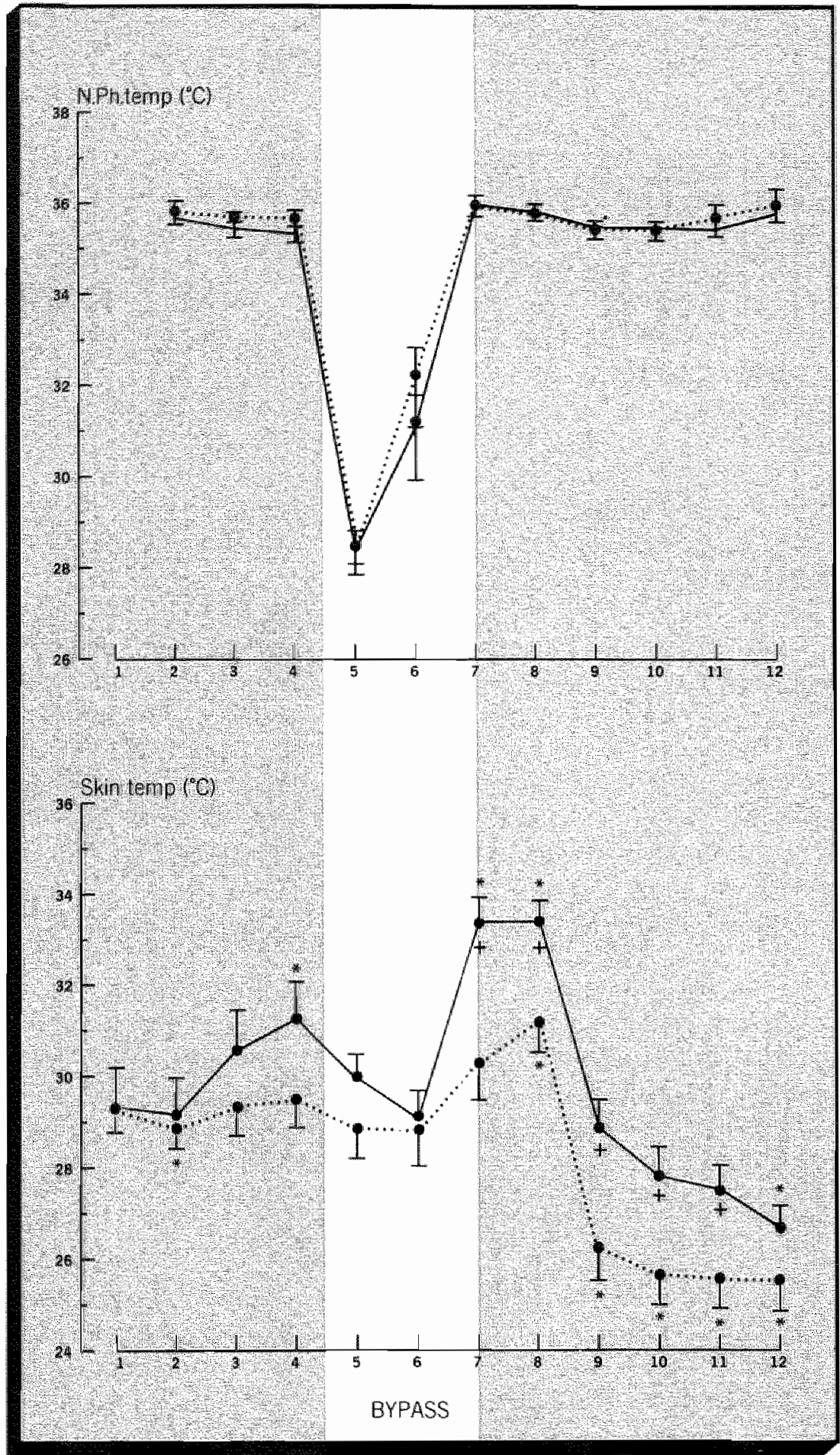


let-bound serotonin tended to increase during $C P B$, but these changes did not reach the level of significance. The platelet count significantly decreased during $\mathrm{CPB}$. The changes in the platelet parameters between the two groups were not significantly different (table 2).

Table 4.2 .

Platelet count and plasma levels of beta-thromboglobulin, platelet factor -4 , serotonin and platelef bound serotonin in both groups during and following surgery.

\begin{tabular}{|c|c|c|c|c|c|c|}
\hline & $T$ & $\begin{array}{c}\text { Platelet } \\
\text { count }\left(\times 10^{3}\right)\end{array}$ & $\begin{array}{c}\text { bTG } \\
(\mathrm{mg} / \mathrm{ml})\end{array}$ & $\begin{array}{c}\mathrm{PF}-4 \\
(\mathrm{ng} / \mathrm{ml})\end{array}$ & $\begin{array}{c}\text { Ser } \\
(\mathrm{ng} / \mathrm{ml})\end{array}$ & $\begin{array}{c}\text { Plwer } \\
\left(\mathrm{ng} / 10^{3} \mathrm{pl}\right)\end{array}$ \\
\hline \multirow[t]{4}{*}{ Ketanserin } & 1 & $186+22^{*}$ & $47+4.2$ & $26+5.1$ & $58+4.2$ & $60+8.7$ \\
\hline & 8 & $78+31^{*}$ & $175+12.6 *$ & $52+10.2 *$ & $75+5.8$ & $61+12.6$ \\
\hline & 11 & $95+19^{*}$ & $105+8.4 *$ & $23+4.7$ & $64+4.7$ & $56+5.7$ \\
\hline & 12 & $105+22^{*}$ & $96+11.8^{*}$ & $19+6.4$ & $66+3.7$ & $52+84$ \\
\hline \multirow[t]{4}{*}{ Solvent: } & 1 & $193+30$ & $52+8.5$ & $28+3.4$ & $51+4.9$ & $51+7.9$ \\
\hline & 8 & $86+21 *$ & $186+15.8^{*}$ & $46+7.4^{*}$ & $69+6.8$ & $56+9.2$ \\
\hline & 11 & $105+26^{*}$ & $104+11.6^{*}$ & $25+4.5$ & $49+5.1$ & $52+6.8$ \\
\hline & 12 & $109+17^{*}$ & $84+9.5 *$ & $21+3.5$ & $42+3.5$ & $51+7.4$ \\
\hline \multicolumn{7}{|c|}{ 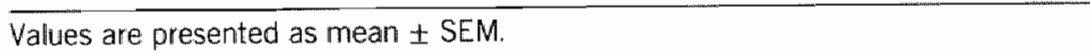 } \\
\hline \multicolumn{7}{|c|}{$\begin{array}{l}\text { bTG }=\text { beta-thromboglobulin; PF- } 4=\text { platelet factor- } 4 \text {; Ser = plasma-serotonin; } \\
\text { PI-ser = platelet-bound serotonin; } p l=\text { platelets; } T=\text { sample moments, for explanation } \\
\text { of } T=1,8,11,12 \text { see Fig. } 1\end{array}$} \\
\hline
\end{tabular}

Fig.4.3.

Nasopharyngeal (NPh) and peripheral (skin) temperature (mean \pm SEM) in the solvent $(. .$.$) ) and ketanserin (-) groups during and following surgery. For explanation$ of recording moments and abbreviations see Fig 4,1 .

* = significantly different from control value $(p<0.05)$

$+=$ significant difference between the groups $(p<0.05$ ) 
Fig. 4.4.

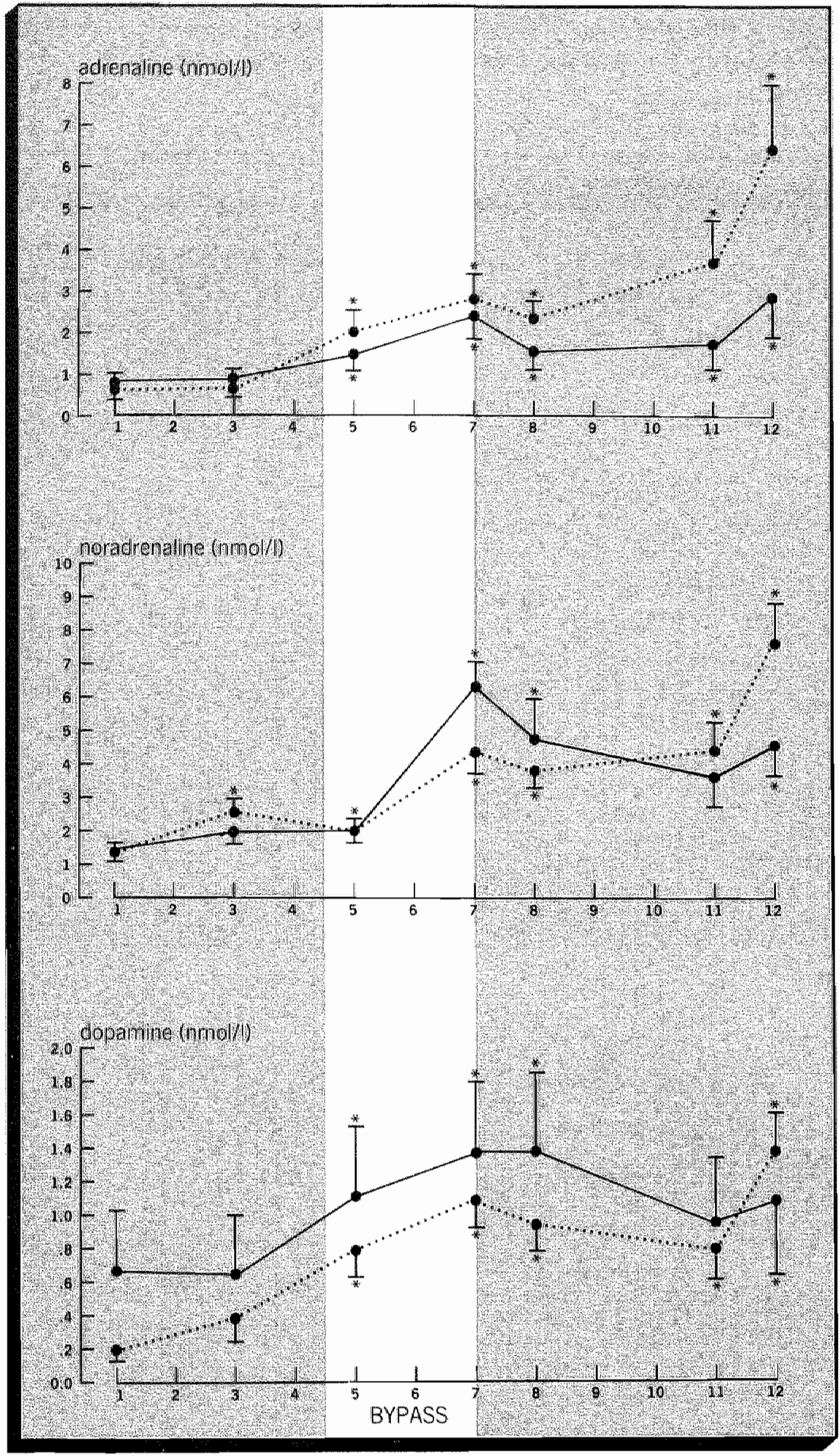


The dose of fentanyl administered to treat hypertensive episodes in the pre-bypass period was significantly lower in group $\mathrm{K}(0.28 \pm 0.03 \mu \mathrm{g} / \mathrm{kg} /$ min) than in group $S(0.36 \pm 0.02 \mu \mathrm{g} / \mathrm{kg} / \mathrm{min})$. In this period nitroglycerin was administered to 2 patients in group $K$ and in all the patients in group $S_{\text {, }}$ a significant difference $(p<0.01)$. In the ICU nitroglycerim was adininistered because of hypertension in 2 patients in group $K$ and in 10 patients in group $S$. This difference was also statistically significant $(p<0.01)$.

In the period prior to $\mathrm{CPB}$ and during $\mathrm{CPB}$ diuresis (fig 6 ) was significantly higher $(p<0.01$ and $p<0.05$, respectively) in group $K$ than in group S, but in the post-CPB period there was no significant difference between the two groups anymore.

\section{Discussion}

The findings in the study show that, as compared with the solvent, the contimuous infusion of ketanserin is associated with significantly lower arterial blood pressure, heart rate and cardiac output values in patients undergoing coronary artery bypass grafting, particularly in the post-bypass period. Systemic vascular resistance is slightly, but significantly higher in the corresponding periods. Ketanserin induces a lower pulmonary artery pressure in the early postoperative period and a higher peripheral skin temperature during and following cardiopulmonary bypass. Ketanserin also causes a better diuresis before and during bypass. During the continuous infusion of ketanserin the need for the administration of fentanyl and nitroglycerin to treat hypertensive reflexes is significantly less than during solvent infusion. The higher heart rate values in the solvent-group can possibly be explained by more frequent administrations of nitroglycerin, which may cause reflex tachycardia (Kaplan et al.1980). In a previous study comparing ketanserin and sodium nitroprusside in the treatment of postoperative hypertension following coronary artery bypass grafting (Van der Starre and Reneman 1986), ketanserin, in contrast to nitroprusside, lowered arterial blood pressure without changing heart rate. Since myocardial

Fig.4.4.

Plasma levels (mean \pm SEM) of adrenaline (top), noradrenaline (middle) and dopamine (below) in the solvent $(\ldots)$ and ketanserin (-) groups during and following surgery. For explanation of sampling moments and abbreviations see Fig.4.1.

* = significartly different from control value $(p<0.05)$

$+=$ significant difference between the groups $(\rho<0.05)$ 
Fig. 4.5

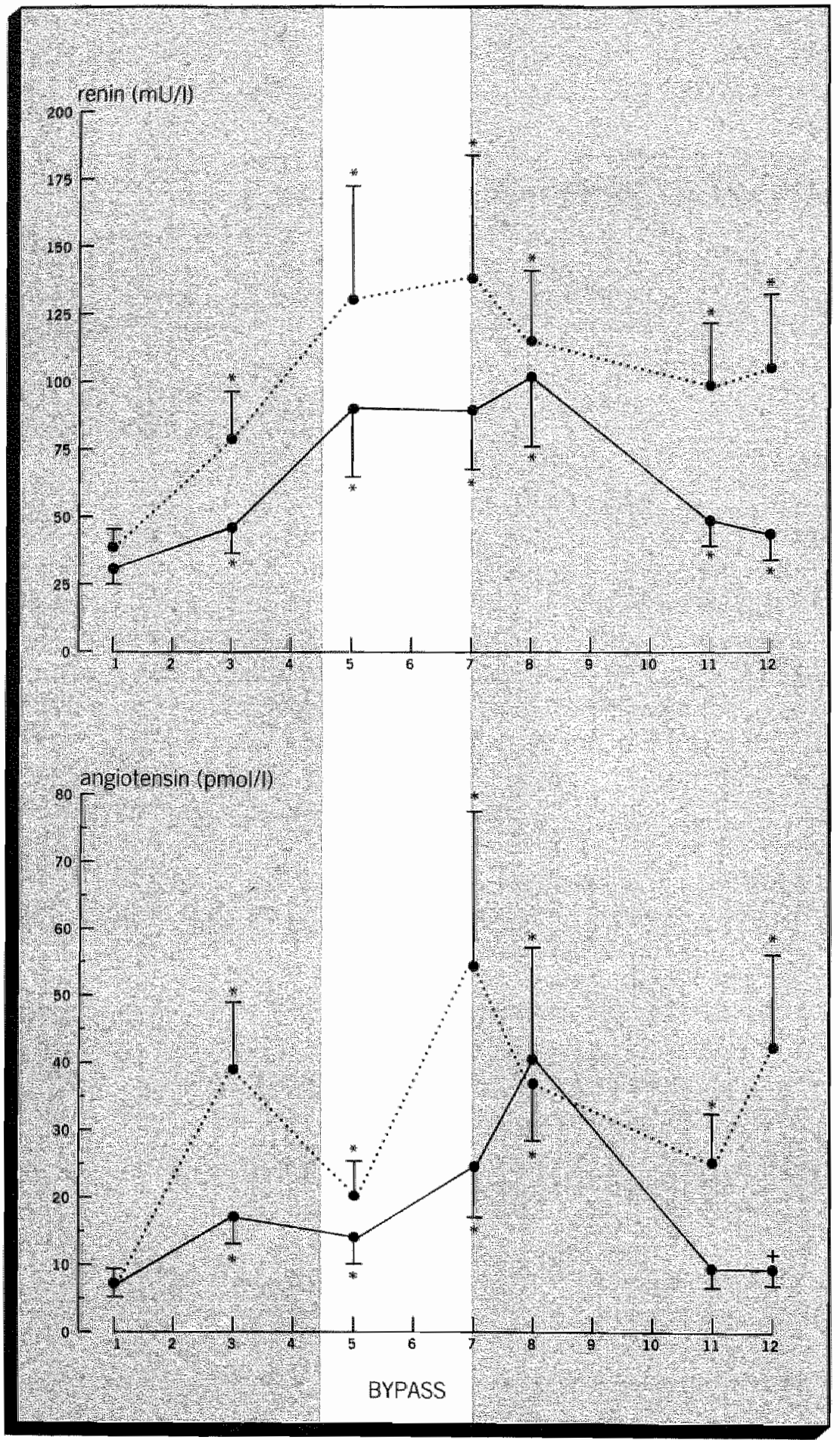


oxygen demand is mainly determined by heart rate and systolic arterial blood pressure (Braunwald 1971, Hoffman and Buckberg 1978), Ketanserin potentially improves the balance between oxygen demand and supply.

The slightly lower systemic vascular resistance in the solvent group during the intensive care period may also be explained by the more frequent administrations of nitroglycerin to treat hypertensive episodes in this group. The significantly higher peripheral temperature in the ketanserin group during corresponding periods might be explained by a specific dilating effect of the compound on cutaneous blood vessels. The antihypertensive activity of ketanser in was recently attributed to an interaction between $\mathrm{S}_{2}$-serotonergic and alpha $\mathrm{a}_{1}$-adrenergic receptor blockade, since $\mathrm{S}_{2}$-serotonergic receptor blockade alone does not change arterial blood pressure (Van der Starre and Reneman 1988, Van Nueten et al.1986).

In both groups the plasma levels of adrenaline, noradrenaline and dopamine remained stable during the pre-bypass period, but increased during cardiopulmonary bypass, whereas the plasma levels of renin and angiotensin already increased in the pre-bypass period. These humoral responses are in agreement with previous findings (Roberts et al.1977. Balasarawahti et al.1978, Low et al.1986, Bailey et al.1975, Taylor et al.1979) and are probably caused by the use of hemodilution (Hine et al.1976), hypothermia (Arnett and Watts 1960, Chernow et al.1983) and non-pulsatile flow (Landymore et ai.1979). The findings in the solvent group confirm previous observations that during anesthesia with moderate doses of opioids (up to $75 \mu \mathrm{g} / \mathrm{kg}$ fentanyl), muscle relaxants and hypnotic agents a vasodilating compound like nitroglycerin has to be administered to modulate extreme pressor responses (Dahlgren and Messeter 1981, Bovill et al.1984, Bedford and Marshall 1984, Kay et al.1985, Moffitt 1978). The lower dose of fentanyl administered in the ketanseringroup might be beneficial because of a shorter postoperative recovery time, although this was not recorded in the present study.

The observation that before and during cardiopulmonary bypass diuresis is significantly better during the infusion of ketanserin than during the

Fig 4.5 .

Plasmalevels (mean $t$ SEM) of renin (top) and angiotensin II (below) in the solvent $(\ldots .$.$) and ketanserin (-) groups during and following surgery. For explanation of$ sampling moments and abbreviations see Fig.4.1.

* significantly different from control value $(\rho<0.05)$

+ significant difference between the groups $(p<0.05)$ 
infusion of solvent might be explained by the finding that ketanserin blocks the serotonin induced constriction of renal arteries in animals (Garattini and Valzelli 1965, Blackshear et al.1986, Page and McCubbin 1953).

In both groups activation and aggregation of platelets occurred during cardiopulmonary bypass, as indicated by the significant increase of plasma levels of beta-thromboglubin and platelet factor-4. This is in agreement with earlier observations (Kobinia et al.1986, Faymonville et al.1986, Solis et al.1975). It has been suggested (Replogle et al.1962, Swank et al.1964, llicin et al.1972) that serotonin released from platelets activated during cardiopulmonary bypass might contribute to the vaso-

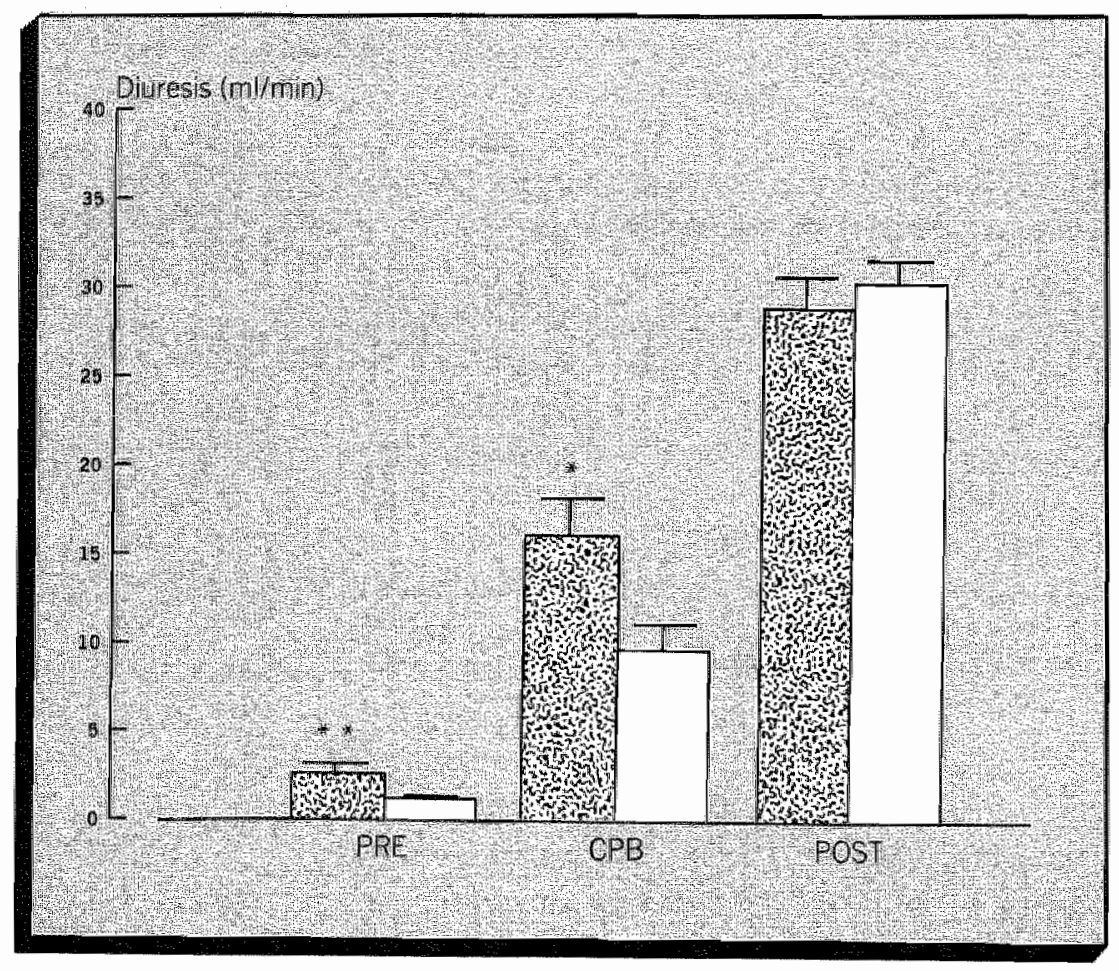

Fig.4.6.

Diuresis (mean $\pm \mathrm{SEM}$ ) pre-CPB during CPB and post-CPB in the solvent ( and ketanserin (

* = significant difference between the groups $(p<0.05$ )

* = significant difference between the groups $(p<0.01)$ 
pressor response. However, elevations of plasma levels of serotonin are not uniformly detected (Anger et al.1985, this study) suggesting that circulating platelets in patients during cardiopulmonary bypass are activated through a process involving release from $\alpha$-granules (beta-thromboglobulin, platelet factor-4) but not of dense granule constituents (serotonin)(Harker et al.1980). However, the failure to demonstrate increased plasma levels of serotonin may also be due to the particular kinetic behaviour of the mono-amine in the circulation and does not necessarily exclude a serotonergic contribution to the hypertension observed during and following surgery. Indeed, release of serotonin by the platelets and re-uptake of the mono-amine by these activated cells, as well as the endothellial lining of the vessel wall, are time-sharing processes (Costa and Murphy 1977, Reimers et al.1973). Low-grade release from platelets thus may provide serotonin to act in concert with other vasopressors (Van Nueten et al.1982), while concomitant re-uptake yields apparently normal plasma and platelet levels.

in conclusion a continuous infusion of ketanserin during and following coronary artery bypass grafting significantly lowers arterial blood pressure, heart rate and cardiac output per-and postoperatively as opposed to its solvent. The administration of ketanserin reduces the need for opioids and nitroglycerin to treat hypertensive episodes, which might be beneficial in preventing side-effects like rigidity, postoperative respiratory depression and tachycardia. Diuresis is significantly better during the administration of ketanserin than of its solvent. Although platelet counts and plasma levels of serotonin did not significantly change, a substantial role of serotonin in the genesis of perioperative hypertension cannot be excluded.

\section{Summary}

In a prospective double-blind study in patients undergoing coronary artery bypass grafting ( $C A B G$ ), the effects of a continuous infusion of ketanserin $0.1 \mathrm{mg} / \mathrm{kg} / \mathrm{hr}$, a S ${ }_{2}$-serotonergic receptor blocking compound with $\alpha_{1}$-adrenergic receptor blocking properties, were compared with those induced by the infusion of the solvent of ketanserin. Both infusions were started immediately after intubation. The solvent and the ketanserin group each consisted of 12 patients. A comparison was made between the effects on systemic and pulmonary hemodynamics, plasma levels of circulating adrenaline, noradrenaline, dopamine, renin, angiotensin $\|_{\text {, serotonin, beta- }}$ thromboglobulin and platelet factor-4, diuresis, and the dose of fentaryl and the number of nitroglycerin administrations required to treat hypertensive episodes during and following surgery. In the treated group arterial 
blood pressure, heart rate and cardiac output were significantly lower $(p<0.05)$, mainly in the post-bypass period, whereas skin temperature and systemic vascular resistance were significantly higher $(p<0.05)$ at corresponding moments. Before $(p<0.01)$ and during cardiopulmonary bypass $(p<0.05)$, diuresis was significantly higher whereas the dose of fentanyl and the number of nitroglycerin administrations required were significantly lower ( $p<0.05$ and $p<0.01$, respectively). It is concluded that the continuous infusion of ketanserin leads to a more stable condition with less hypertensive episodes during and after CABG, which may benefit patients at risk. 


\section{Chapter 5}

The use of ketanserin, a $\mathrm{S}_{2}$-serotonergic receptor antagonist, for treatment of postoperative hypertension following coronary artery bypass surgery 


\section{Introduction}

Hypertension following coronary artery bypass surgery occurs in 30-60\% of patients during the first few postoperative hours (Estafanous et al.1973,Estafanous and Tarazi 1980, Roberts et al. 1977, Salemo et al.1981). Several factors may contribute to the development of this postoperative hypertension including arousal, nasopharyngeal and tracheal stimulation, and pain. Increased levels of circulating catecholamines, renin, angiotensin, and/or serotonin may be involved in the development of hypertension (Balasaraswathi et al.1978, Wallach et al.1980, Taylor et al.1977,Frick 1960, Replogle et al.1962). Serotonin may either be released from platelets activated during the extracorporeal circulation or gradually released from e.g. the spleen in the postoperative period (Wenzel et al.1979). Whether seratonin-induced cardiagenic hypertension reflex (James et al.1975) plays a role in this type of postoperative hypertension is unknown.

\section{Methods}

Of $82 \mathrm{NY} H \mathrm{HA}$ category II/III patients, not in heart failure and undergoing elective coronary artery bypass surgery, 40 patients (49\%) developing hypertension during the early postoperative period (110-180 min after the end of surgery; median $132 \mathrm{~min}$ ), were studied. In all patients with arteriographically confirmed coronary artery bypass disease, the coronary lesions were bypassed by saphenous vein grafts. Preoperative management, the anesthetical and surgical technique and postoperative care were standardized (chapter 5). All patients gave informed consent; the study was approved by the ethics committee of the hospital.

Preoperative therapy consisting usually of beta-adrenergic antagonists, long-acting nitrates, and calcium-antagonists was continued during hospitalization until the night before surgery. Patients were not given anticoagulants either before or after surgery.

Premedication with $0.005 \mathrm{mg} / \mathrm{kg}$ scopolamin and $0.125 \mathrm{mg} / \mathrm{kg}$ morphine was administered intramuscularly 45 min before induction of anesthesia.

Anesthesia was induced intravenously with $0.3 \mathrm{mg} / \mathrm{kg}$ etomidate, $0.5 \mathrm{mg}$ fentanyl, and $0.15 \mathrm{mg} / \mathrm{kg}$ pancuronium; the patients were mechanically ventilated with a mixture of $50 \%$ nitrous oxide and $50 \%$ oxygen. Ventilation was governed by the capnographically determined $\mathrm{CO}_{2}$ concentration in expired air (Mijnhardt) and by serial measurements of arterial blood gas tensions. Incremental doses of $0.25-0.5 \mathrm{mg}$ of fentanyl 
and $0.1 \mathrm{mg} / \mathrm{kg}$ of pancuronium were given intravenously before median sternotomy, during cardiopulmonary bypass, and before closure of the sternum. Anesthesia was adjusted according to response of the eciectroencephalogram (EEG) as well as changes in blood pressure, heart rate, and peripheral circulation. Incidental hypertension during the surgical procedure was treated with intravenous injections of nitroglycerin.

Heparin ( $3 \mathrm{mg} / \mathrm{kg}$ ) was administered intravenously betore extracorporeal circuit (ECC), which consisted of an arterial and a wenous roller pump (Sams), and a bubble oxygenator (Bentley, Harvey). The calculated flow was $50 \mathrm{~m} / \mathrm{kg}$. The priming solution consisted of 5\% dextrose in Ringer's lactate solution, $20 \mathrm{ml} / \mathrm{kg}$, with 50 meq bicarbonate and $50 \mathrm{mg}$ heparin $/ \mathrm{L}$ of the priming solution. Mean arterial pressure during ECC was kept at $50 \mathrm{mmHg}$, regulated by vasodilating drugs like trimethaphan and nitroglycerin. The patients were cooled to a nasopharyngeal temperature of $28^{\circ} \mathrm{C}$ with a heat exchanger. The heart was stopped by ventricular fibrillation or by a cardioplegic solution containing 30 meq potassium $/ L$. Topicai cooling of the heart was performed in all patients. After installation of the last distal anastomosis, the patients were rewarmed to normothermia $\left(1^{\circ} \mathrm{C} / 3 \mathrm{~min}\right)$. The mean hematocrit at the end of ECC was $28 \%$. After termination of the ECC, heparin was antagonized by protamine $(3 \mathrm{mg} / \mathrm{kg}$ intravenously). The residual priming solution was transferred to the patient through a transfusion system, guided by central venous and left arterial pressures.

Artificial ventilation was continued during transfer to the intensive care unit and as long as the patients remained asleep to maintain a $\mathrm{PaCO}_{2}$ of $35-45 \mathrm{mmHg}$ and $\mathrm{PaO}_{2}$ of $100-150 \mathrm{~mm} \mathrm{Hg}$. During this time $1 \mathrm{ml} / \mathrm{kg} / \mathrm{h}$ of $5 \%$ dextrose in Ringer's lactate solution was infused to maintain urine output at $0.8 \mathrm{ml} / \mathrm{kg} / \mathrm{h}$. All patients had adequate sedation and analgesia and were free of respiratory difficulties. Calculated blood losses were replaced as indicated by changes in arterial blood pressure, central venous pressure, and left atrial pressure.

ECG leads II and $V_{5}$ were applied upon arrival of patients in the operating theatre, at which time an intravenous infusion catheter ( 16 gauge) and a radial arterial cannula (18 gauge) for arterial blood pressure (AP) monitoring were also inserted. After induction of anesthesia, a catheter (16 gauge) was introduced through the jugular vein for monitoring central venous pressure (CVP). In one group of patients $(N=10)$, a Swan Ganz thermodilution catheter was inserted through the right internal jugular vein to measure pulmonary artery pressure (PAP). Cardiac output (CO) was measured using the thermodilution technique (Edwards Laboratories) (Kohanna, Cunningham 1977). Systemic vascular resistance (SVR) was calculated as follows: SVR $=80 \times$ (mean arterial pressure (MAP) - CVP 
/ CO dynes. $\mathrm{cm}^{-5}$. At the end of ECC, a catheter was placed in the left atrium at its junction with the superior pulmonary vein for monitoring left artrial pressure (LAP). All catheters were left in place for at least $48 \mathrm{~h}$. The triple index was calculated by multiplying heart rate (beats $/ \mathrm{min}$ ) by systolic blood pressure $(\mathrm{mmHg})$ and LAP $(\mathrm{mmHg})$.

Peripheral circulation was monitored using a plethysmograph applied to the ear lobe. Temperature sensors were placed on the forehead skin and in the nasopharynx. Upon arrival in the intensive care unit, the latter was replaced by a rectal probe. Capnographic recording of expired $\mathrm{CO}_{2}$ was continued while patients remained in the intensive care unit.

A hypertensive episodle was defined as a period of sustained increase in arterial systolic blood pressure ( $150 \mathrm{mmHg}$ ) when the increase in blood pressure was not reversed by simple sedation or analgesia; when there was no evidence of hypoxia, hypercarbia, shivering, or intolerance of the endotracheal tube; and when right and left filling pressures of the heart were adequate (CVP 5-10 $\mathrm{mmHg}$; LAP 5-12 mmHg).

Intravenous administration of ketanserin was started when the intraarterial systolic blood pressure increased above $150 \mathrm{mmHg}$. patients were sequentially allocated to one of three groups. Patients in group $1(\mathrm{~N}=15)$ were treated with an intravenous bolus of $10 \mathrm{mg}$ of ketanserin injected over a period of $3 \mathrm{~min}$. Patients in group $2(\mathrm{~N}=15)$ had continuous infusions of $4 \mathrm{mg}$ of ketanserin per $\mathrm{h}$ for $2.5 \mathrm{~h}$ within $10 \mathrm{~min}$ after injection of $10 \mathrm{mg}$ of ketanserin. Patients in group $3(\mathrm{~N}=10)$ had an intravenous injection of $10 \mathrm{mg}$ of ketanserin followed by continuous infusions of $4 \mathrm{mg}$ of ketanserin for $1 \mathrm{~h}$ also within $10 \mathrm{~min}$. In group $3 \mathrm{CO}$ was measured and SVR calculated. If, however, the bolus injection of ketanserin did not result in a decrease of blood pressure within 10 min, nitroglycerin was administered to normalize blood pressure.

In all patients AP, heart rate, CVP, and LAP were measured before and 5 , 15,30 , and 60 min after injection of ketanserin. In group 2 these variables were also recorded after 90,120 , and $150 \mathrm{~min}$. In group 3, CO and SVR were determined before and 15 and 60 min after ketanserin administration.

Differences between values of the different variables before and at various intervals after the administration of ketanserin were evaluated for statistical significance by a paired t-test. A Mann-Whitney $U$ test was used for statistical evaluation of the differences between the control values of the various variables (before ketanserin injection) in the three groups. 


\section{Results}

The sex, age, and weight distributions of the patients in the three groups are shown in Table 1 with the number of bypass grafts and the duration of $\mathrm{CPB}$, surgery, and anesthesia.

Table 5.1 Sex, Age, Weight Distribution, and Number of Bypasses, as well as the Duration of ECC, Surgery, and Anesthesia in the Patients Treated with Ketanserin. (Mean \pm SEM.)

\begin{tabular}{lrrrr}
\hline & \multicolumn{1}{c}{ Group 1 } & Group 2 & \multicolumn{1}{c}{ Group 3 } \\
\hline Sex (\% males) & \multicolumn{1}{c}{84.6} & & 91.7 & 75.0 \\
Age (years) & $58.3 \pm 1.97$ & $56.5 \pm 2.58$ & $53.5 \pm 2.33$ \\
Weight (kg) & $74.5 \pm 3.14$ & $73.3 \pm 2.91$ & $78.9 \pm 5.65$ \\
Number of bypasses & $3.8 \pm 0.41$ & $2.9 \pm 0.19$ & $3.3 \pm 0.37$ \\
Duration of ECC (min) & $78.5 \pm 6.72$ & $66.75 \pm 6.19$ & $76.0 \pm 7.29$ \\
Duration of surgery (min) & $200.8 \pm 9.64$ & $175.8 \pm 4.76$ & $211.3 \pm 15.55$ \\
Duration of anesthesia (min) & $236.9 \pm 11.17$ & $204.2 \pm 5.50$ & $247.5 \pm 16.09$ \\
\hline
\end{tabular}

No serious complications occured during surgery in any of the patients. Mean blood loss during surgery was $400 \mathrm{ml}$. Urine production remained stable and normal during the surgical procedure as well as postoperatively. None of the patients developed hypo- or hyperthermia during the first 4 postoperative hours. Except for the lower systolic AP values in group 3 and the higher diastolic AP values in group 2 (Fig. 1), there were no significant differences between the values of the three groups before administration of ketanserin.

The bolus injection of $10 \mathrm{mg}$ of ketanserin has a significant effect of too short duration on the hypertension in two patients in group 1 , in three patients in group 2, and in two patients in group 3 . In all of these patients $(7 / 40,17.5 \%)$ AP was normalized with an average infusion dose of $1.5 \mathrm{ug} /$ $\mathrm{kg} / \mathrm{min}$ nitroglycerin. The results (AP and HR) obtained in these patients are illustrated in Figure 2. In the remaining patients, AP decreased signiticantly to normal values immediately following the administration of $10 \mathrm{mg}$ of ketanserin (Fig. 1). When only the bolus injection was given (group 2), AP gradually increased, systolic pressure reached hypertensive levels again after $60 \mathrm{~min}$. The hypotensive effect of a bolus injection could be maintained with a continuous infusion of $4 \mathrm{mg}$ of ketanserin/h (groups 2 and 3). No rebound effect was observed after discontinuation of the infusions (Fig. 1). Heart rate decreased slightly but statistically significantly during continuous infusion of ketanserin (Fig. 3), while SVR decreased 


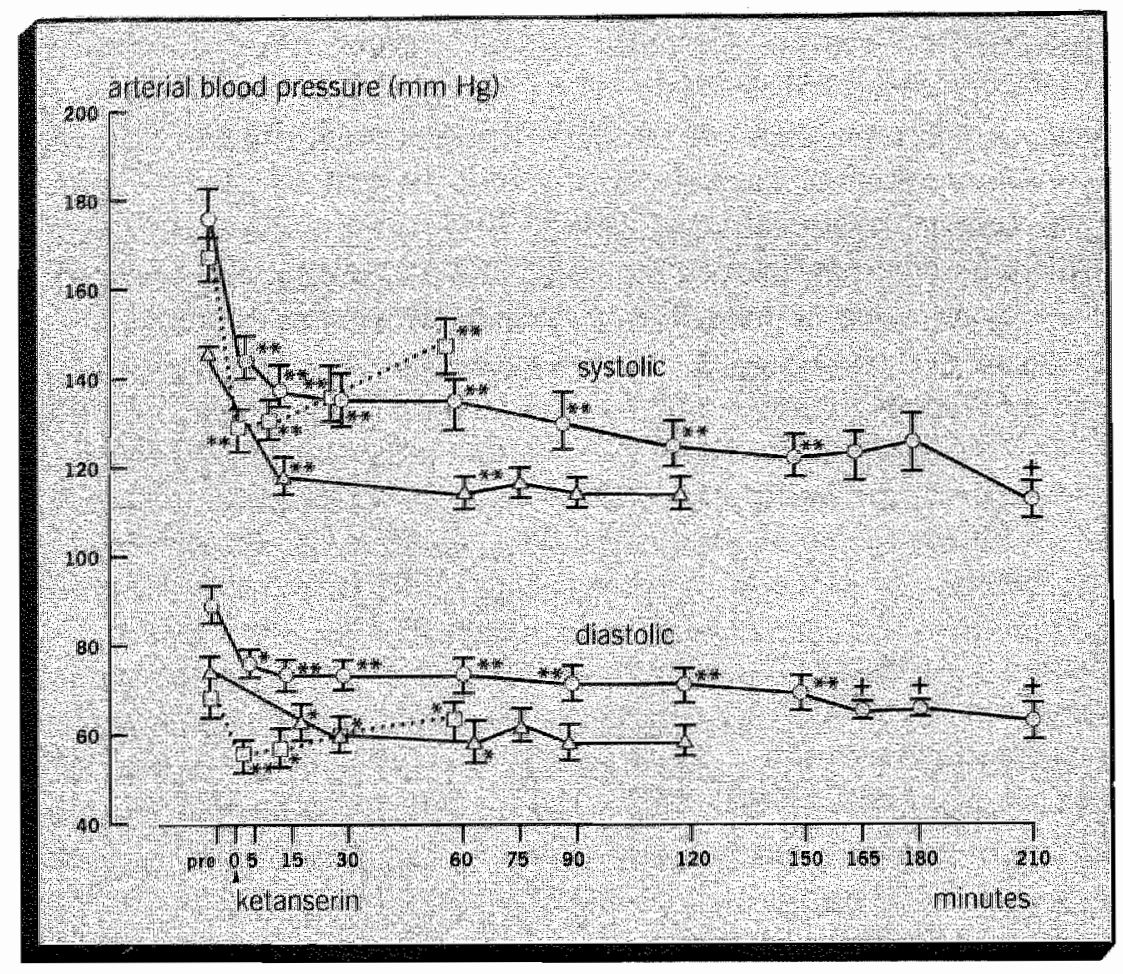

Fig 5.1

Effect of ketanserin on systolic and diastalic arterial blood pressure.

$\mathrm{c}=$ group 1: $10 \mathrm{mg}$ of ketanserin $\mathrm{V}(\mathrm{n}=13)$

$\mathrm{O}=$ group 2: $10 \mathrm{mg}$ of ketanserin IV followed by $4 \mathrm{mg}$ of ketanserin/h $\mathrm{V}$ for $2.5 \mathrm{~h}$ $(\mathrm{n}=12)$

$A=$ group $3: 10 \mathrm{mg}$ of ketanserin IV tollowed by $4 \mathrm{mg}$ of ketanserin/hn $\mathrm{W}$ for $1 \mathrm{~h}$ $(n-8)$

$*$ * $p<0.05$ (significant difference from pretreatment values)

t. $=0<0.001$ (significant difference from pretreatment values)

$+=p<0.05$ (signiticant difference from value at end of treatment)

Fig 5.2

Course of systolic (SBP) and diastolic (DBP) arterial blood pressure and heart rate $($ HE) in patients $(n=7)$ treated with a continuous infusion of nitroglycerin because response to ketanserin was too brief $(10 \mathrm{~min})$.

$*=p<0.05$ (significant difference from pretreatment values) 
significantly and cardiac output increased significantly (Fig. 4). Ketanserin had no substantial effect on PCWP or CVP. The administration of ketanserin was followed by a significant decrease in triple index (Fig. 5).

\section{Discussion}

The findings in the present study show that ketanserin, a specific $S_{2}$-serotoninergic receptor blocking agent, is effective in the treatment of hypertension following coronary artery bypass surgery. An intravenous bolus injection of the compound (10 $\mathrm{mg}$ ) rapidly decreased arterial blood pressure to normal levels in $82.5 \%$ of patients. This level could be maintained with a continuous infusion of $4 \mathrm{mg}$ of ketanserin/h following the bolus injection. No rebound phenomena were observed after discontinuation of the infusion. The decrease in arterial blood pressure most likely represents vasodilation of constricted vessels as indicated by the pronounced decrease of systemic vascular resistance to normal leveis.

The antihypertensive activity of ketanserin was associated with either a slight decrease or no significant change in heart rate. The resulting decrease in triple index suggests that oxygen demands of the myocardium

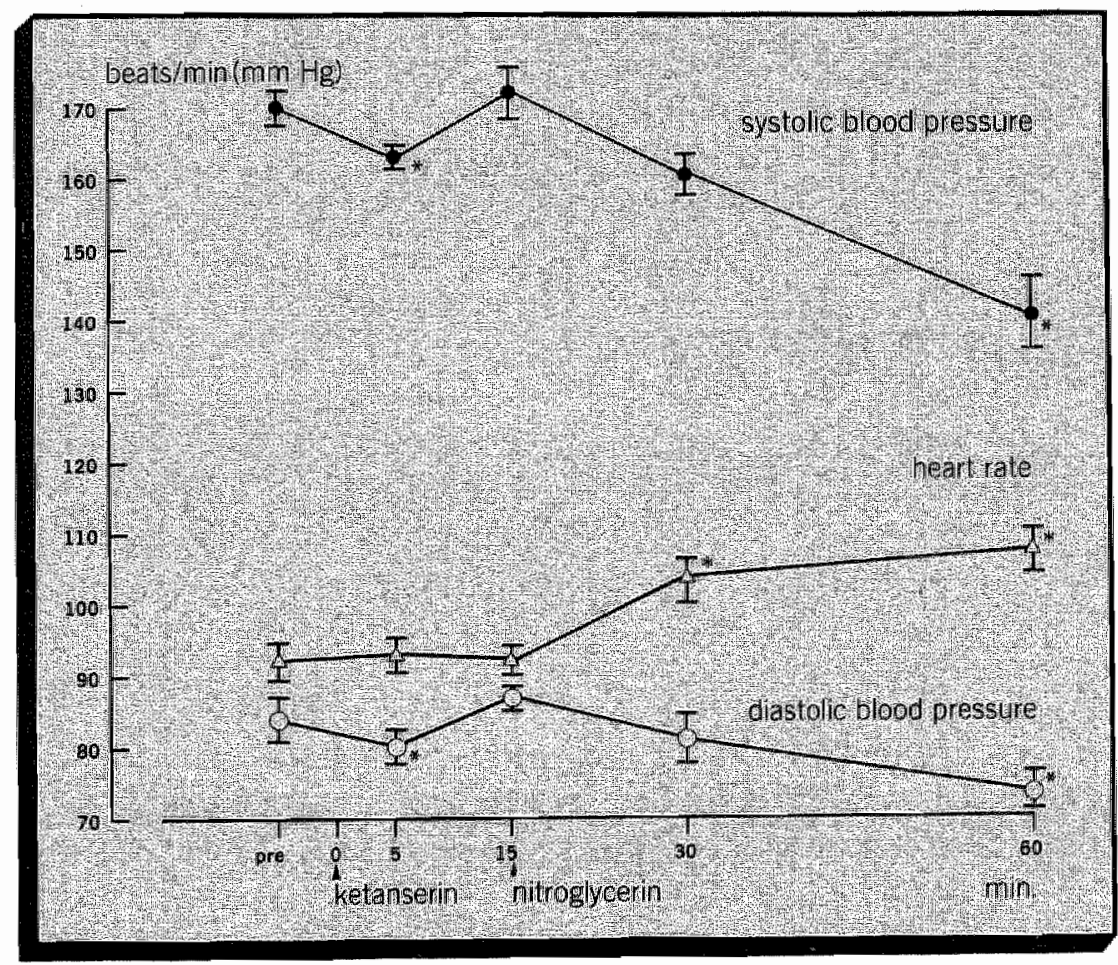




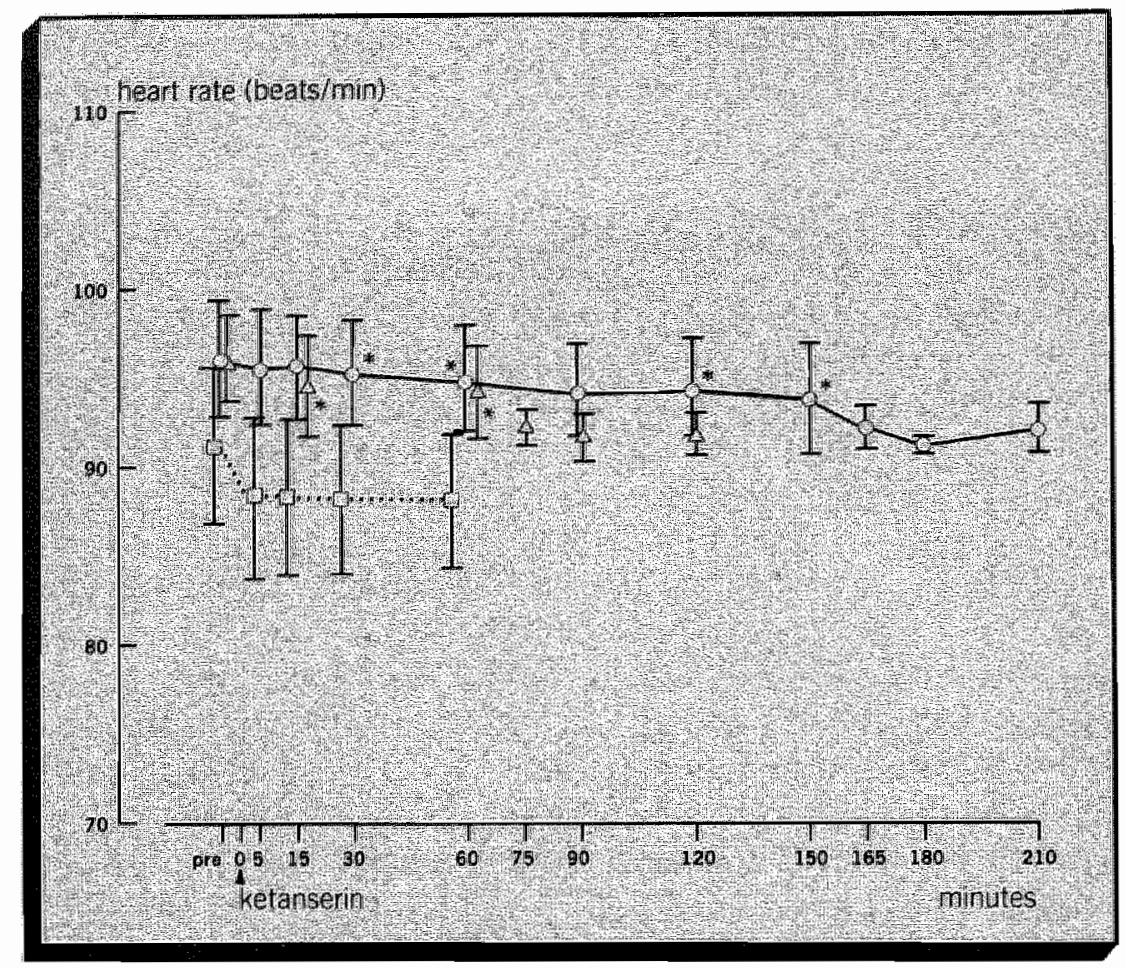

Fig 5.3

Effect of ketanserin on heart rate. See Fig 5.1 for legend.

Fig 5.4

Effect of ketanserin on systemic vascular resistance, mean arterial blood pressure and cairdiac output in pattents treated with $10 \mathrm{mg}$ of ketanserin IV followed by $4 \mathrm{mg}$ of ketanserin/h IV for $1 \mathrm{~h}(\mathrm{n}=8)$.

* $=p<0.05$ (significant difference from pretreatment values)

$* * 0<0.001$ (significant difference from pretreatment values) 

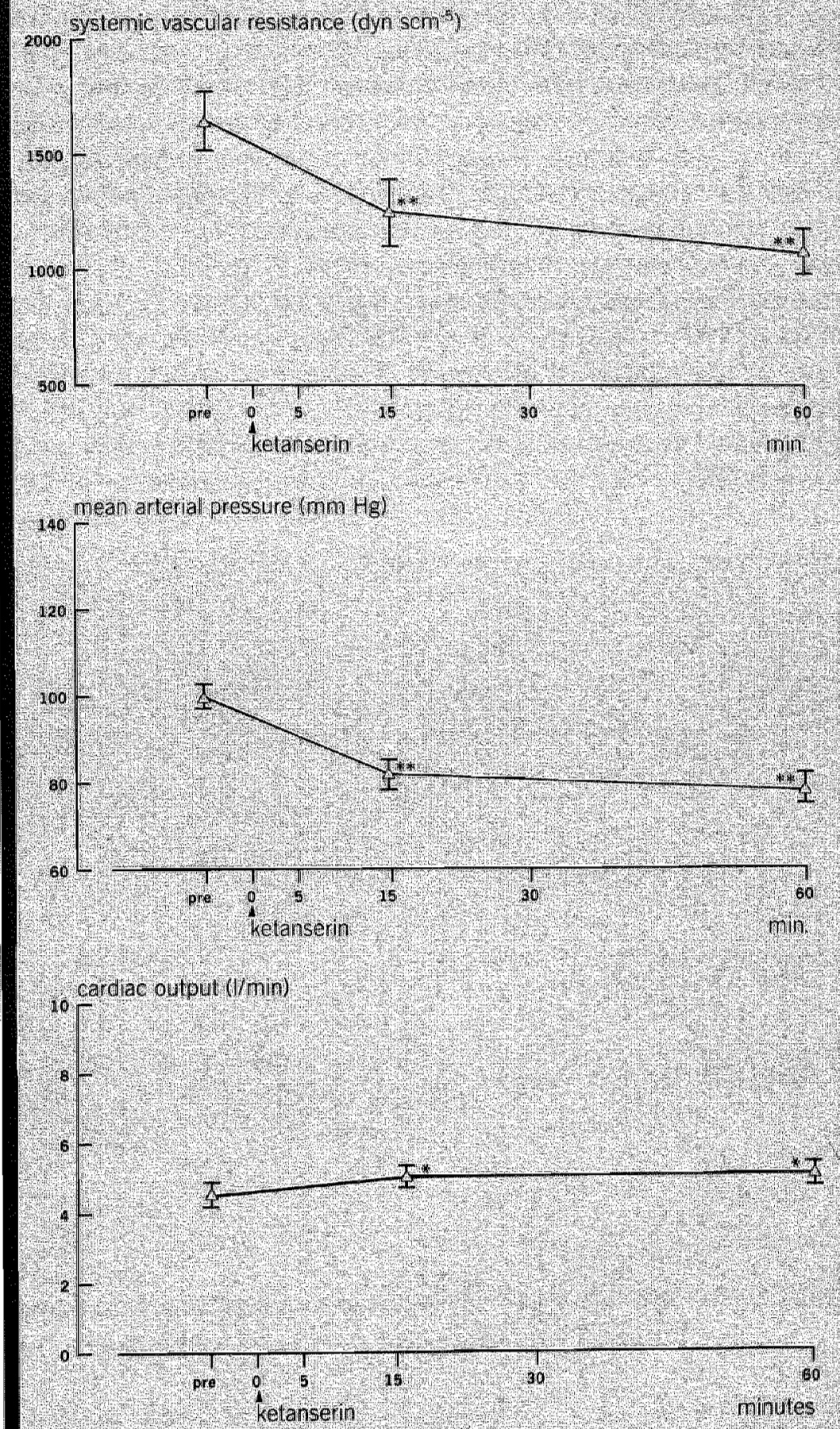
were diminished by ketanserin, an advantage in the presence of potential myocardial ischaemia. Why the pronounced decrease in arterial blood pressure was associated with a decrease rather than an increase in heart rate is mot completely understood. One explanation may be that ketanserin reaches the brain in sufficiently high concentrations to induce a partial centrally mediated hypotension, since ketanserin is known to bind to $\mathrm{S}_{2}$ receptors in the brain (Laduronet al.1984). On the other hand, it is still a point of debate as to wether the serotonin released from platelets does exchange with serotonin in the brain.

The findings of this investigation could support the concept that serotonin is involved in the hypertension often seen following coronary artery bypass surgery (Estafanous et al.1973, Estafanous and Tarazi 1980, Roberts et al.1977. Salerno et al. 1981) The delayed onset of hypertension might support the hypothesis that the serotonin originates from the activated platelets (Wenzel et al.1979) and is then gradually released into the

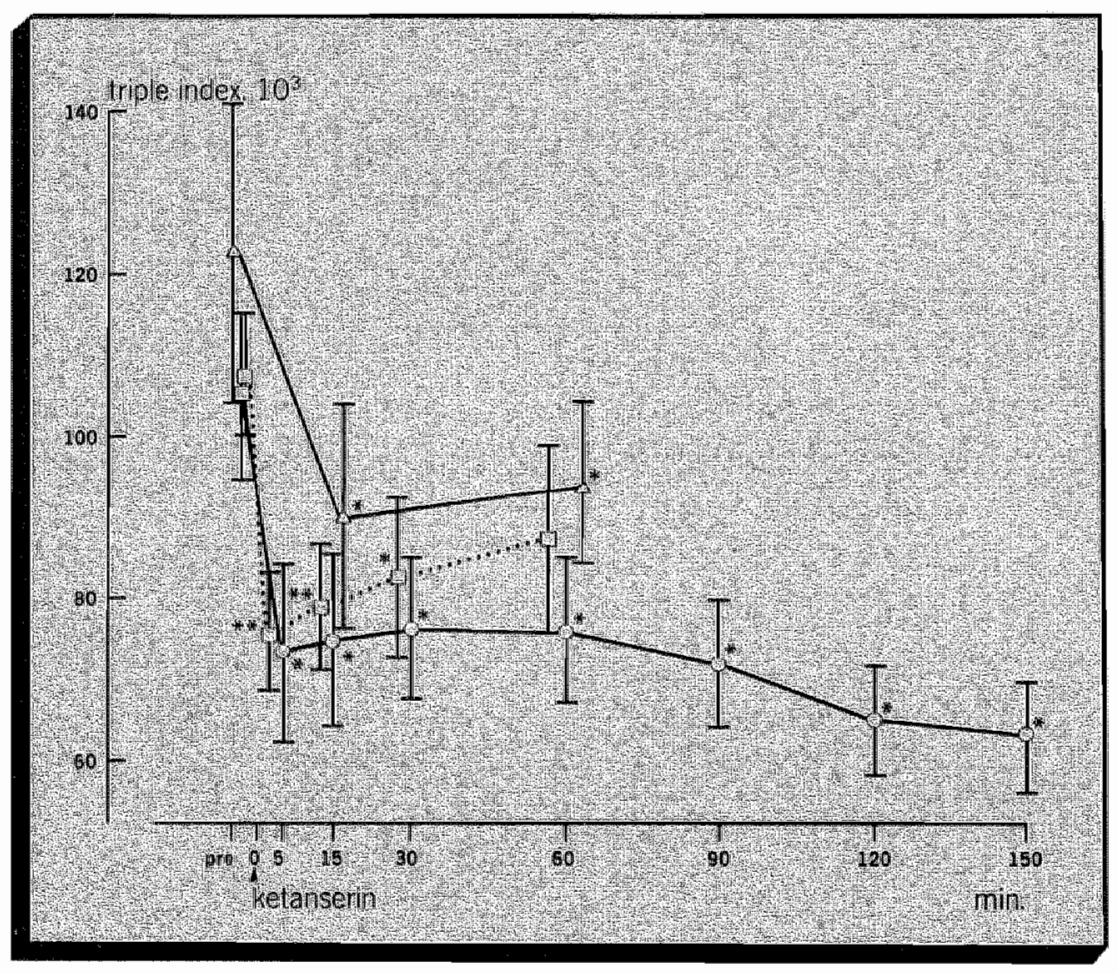

Fig 5.5

Effect of ketanserin on triple index. See Fig 5.1 for legend. 
circulation during the early part of the postoperative period. Whether the serotonin induced cardiogenic reflex (James et al.1975) plays a role in this postoperative hypertension cannot be concluded from the present study.

The lower initial systolic arterial blood pressure values in patients in group 3 than in patients in the other two groups may have been the result of the earlier administration of ketanserin.

Seven of the 40 (17.2\%) patients treated for postoperative hypertension did not respond to ketanserin. One explanation may be that the dose of ketanserin administered in these patients was too low. Another possibility is that the elevated arterial bood pressure in these patients was not caused by serotonin.

In conclusion hypertension following coronary artery bypass surgery may be related to increased circulating levels of serotonin as evidenced by the responses to a $\mathrm{S}_{2}$-serotonergic receptor antagonist ketanserin. The usefullness of ketanserin in the treatment of hypertension following coronary artery bypass surgery may be particularly great because of the absence of reflex increases in heart rate.

\section{Summary}

In patients developing hypertension following coronary artery bypass surgery (CABG) the possible role of serotonin was investigated by injecting ketanserin, a specific $\mathrm{S}_{2}$-serotonergic receptor antagonist. Ketanserin was administered intravenously when intraarterial systolic blood pressure (SAP) exceeded $150 \mathrm{mmHg}$ either as a $10 \mathrm{mg}$ bolus (group $1, \mathrm{~N}=15$ ), or as a $10-\mathrm{mg}$ bolus followed by infusion of $4 \mathrm{mg} / \mathrm{h}$ for either $2.5 \mathrm{~h}$ (group 2 , $N=15$ ) or for $1 \mathrm{~h}$ (group $3, N=10)$. In 33 patients ( $(82,5 \%)$, SAP and diastolic arterial pressure decreased significantly within $5 \mathrm{~min}$ after the 10 mg bolus. In group 1, SAP gradually increased after 30-50 min but in groups 2 and 3 SAP remained normal. The triple index (TI) decreased significantly in all groups. Heart rate decreased slightly but significantly in groups 2 and 3. Central venous and left atrial pressures did not change substantially in any of the three groups. Cardiac output increased significantly $(0.51 \pm 0.158 \mathrm{~L} / \mathrm{min})$; hence, systemic vascular resistance (SVR) decreased significantly ( $452.1 \pm 50.57$ dyn.s.cm ${ }^{-5}$-group 3). No rebound increase in SAP occurred after terminating the infusions (group 2 and 3 ). These findings indicate that serotonin plays a role in the majority of patients who develop hypertension following CABG. The decrease of SVR without reflex tachycardia is a favourable effect of ketanserin. 


\section{Chapter 6}

Ketanserin in the treatment of postoperative hypertension following coronary artery bypass grafting: a double blind study 


\section{Introduction}

Hypertension following coronary artery bypass grafting (CABG) is considered to be a major problem in intensive care units ( Estafanous and Tarazi 1980, Roberts et al. 1977). In addition to anesthetic factors like pain, arousal and intolerance to endotracheal intubation, postoperative hypertension may result from factors such as raised levels of catecholamines (Balasaraswathi et al. 1978), renin, angiotensin (Taylor et al 1977) and serotonin (Replogle et al. 1962, Frick 1980). The possible role of serotonin was substantiated by the earlier finding that ketanserin, a $\mathrm{S}_{2}$-serotonergic receptor blocking agent with $\alpha_{1}$-adrenergic antagonistic properties ( Van Nueten et al. 1981), was effective in the treatment of hypertension following CABG, by decreasing systemic vascular resistance without causing reflex tachycardia (Van der Starre et al. 1983).

The aim of the present double blind study was to prove the effectiveness of ketanserin in the treatment of this type of hypertension.

\section{Materials and methods}

Twenty patients who developed hypertension (see below) during the early recovery phase after CABG were randomly allotted to two groups under double blind conditions. Treatment consisted of either $2 \mathrm{ml}$ solvent or $10 \mathrm{mg}$ ketanserin in $2 \mathrm{ml}$ solvent IV. Both solvent and drug were administered intravenously as a bolus. All patients had given informed consent to participate in this study which was approved by the hospital ethics committee.

The pre-operative medication, in all patients consisting of beta-blocking agents, calcium channel blockers and long-acting nitrates, was continued untill the day of surgery. Preoperatively all patients were normotensive and had a normal left ventricular function, as determined by the ejection fraction and the left ventricular end-diastolic pressure. All patients were NYHA classification II and III.

The anesthetic technique and postoperative management were standardized in both groups (chapter 5). Forty five minutes after intramuscular premedication consisting of $0.005 \mathrm{mg} / \mathrm{kg}$ scopolamine and $0.125 \mathrm{mg} / \mathrm{kg}$ morphine, anesthesia was induced with etomidate $0.2 \mathrm{mg} /$ $\mathrm{kg}$, fentanyl $15 \mu \mathrm{g} / \mathrm{kg}$ and pancuronium bromide $0.15 \mathrm{mg} / \mathrm{kg}$. Anesthesia was maintained with fentanyl (total dose $40-60 \mu \mathrm{g} / \mathrm{kg}$ ), diazepam $0.2 \mathrm{mg} / \mathrm{kg}$ and pancuronium bromide (total dose $0.3 \mathrm{mg} / \mathrm{kg}$ ). The lungs were ventilated with $100 \%$ oxygen. Weaning from the extracorporeal circulation was uneventful in all patients, without the use of any vasopressor 
agent. The patients were mechanically ventilated postoperatively, using $60 \%$ oxygen in air, to keep the blood gas values within acceptable limits ( $\mathrm{PCO}$, between 35 and $45 \mathrm{mmHg}, \mathrm{PO}_{2}$ higher than $100 \mathrm{mmHg}$ ).

Arterial blood pressure was continuously monitored via a radial artery cannula, connected to an external pressure transducer (Bentley). Heart rate was determined from the E.C.G. Hypertension was defined as a period of sustained increase in arterial systolic blood pressure greater than $150 \mathrm{mmHg}$ during at least $5 \mathrm{~min}$, that could not be reduced by sedation or analgesics. The blood pressure and heart rate values were assessed before and $5,10,30$, and 60 min after the administration of the studly medication.

In the interest of the patients" safety and according to the protocol, patients who did not respond adequately to the study medication were treated with a continuous infusion of nitroglycerin. These failures were exclucled from further analysis.

Intragroup differences were evaluated for statistical significance by us-

Table 6.1 General patient data in both treatment groups.

\begin{tabular}{|c|c|c|}
\hline & Ketanserin & Solvent \\
\hline Number of patients treated & 10 & 10 \\
\hline Age (years) & $540+2.21$ & $59.1+3.04$ \\
\hline Sex (F/M ratio) & $1 / 9$ & $5 / 5$ \\
\hline Weight $(\mathrm{kg})$ & $76.0+2.42$ & $72.8+3.38$ \\
\hline Duration of anesthesia (min) & $200.0+10.35$ & $186.5+13.08$ \\
\hline Duration of E.C.C. (min) & $70.1+7.0$ & $64.7+11.19$ \\
\hline Number of bypass grafts & $3.4+0.45$ & $3.1+0.48$ \\
\hline \multicolumn{3}{|l|}{ Onset of treatment } \\
\hline postoperatively (min) & $1450+15.31$ & $122.0+16.85$ \\
\hline \multicolumn{3}{|l|}{ Night before surgery } \\
\hline $\mathrm{SBP}(\mathrm{mm} H \mathrm{Hg})$ & $126.5+5.17$ & $129.7+5.35$ \\
\hline $\mathrm{DBP}(\mathrm{mmHg})$ & $79.8+2.97$ & $78.0+4.96$ \\
\hline$H R(D / m i n)$ & $67.1+4.21$ & $70.2+3.75$ \\
\hline \multicolumn{3}{|l|}{ At lime of } \\
\hline SBP $(\mathrm{mmHg})$ & $158.0+4.22$ & $155.2+5.43$ \\
\hline $\operatorname{DBP}(\mathrm{mm} H \mathrm{~g})$ & $80.3+9.97$ & $76.8+1231$ \\
\hline $\mathrm{HR}(\mathrm{b} / \mathrm{min})$ & $87.0+14.72$ & $90.9+11.26$ \\
\hline
\end{tabular}

$\mathrm{F}=$ lemale; $\mathrm{M}=$ male; $\mathrm{SBP}$ - systolic blood pressure; $\mathrm{DBP}=$ diastolic blood pressure; $H R=$ heart rate (beats/mim): E.C.C. = extracorporeal circulation.

All values are presented as mean \pm SEM. 
ing the Wilcoxon signed rank test, two tailed probability. Intergroup differences were evaluated according to the Mann-Whitney $\mathrm{U}$-Test, two tailed probability. Differences were considered to be significant in case of a probability value $p<0.05$.

\section{Results}

Both groups were comparable with regard to age, sex, body weight, duration of anesthesia, cardiopulmonary bypass time, number of bypass grafts and the onset time of postoperative antihypertensive treatment. At the time of treatment the systolic (SBP) and diastolic blood pressure (DBP) and heart rate (HR) values were not significantly different in the two groups, nor were they different on the day before surgery (table 1 ). The mean values ( \pm SEM) of SBP, DBP and $H R$ in both groups at $0,5,15,30$ and $60 \mathrm{~min}$ are presented in table 2 , and graphically depicted in the figures 1 and 2. In the ketanserin group SBP decreased significantly during 60 min, DBP during at least 30 min $(p<0.05)$ and HR did not change significantly. At $60 \mathrm{~min} 7$ patients were still present in the study. In the sol-

Table 6.2

Values of systolic and diastolic bloord pressure and heart rate in both groups.

\begin{tabular}{|c|c|c|c|c|c|}
\hline \multicolumn{6}{|c|}{ Ketanserin } \\
\hline Min & 0 & 5 & 15 & 30 & 60 \\
\hline $\mathrm{SBP}$ & $158 \pm 1.3$ & $127 \pm 3.4^{*}$ & $1.35 \pm 4.1^{*}$ & $138 \pm 4.3^{*}$ & $127 \pm 8.5^{*}$ \\
\hline DBP & $80 \pm 32$ & $63 \pm 28^{*}$ & $65 \pm 3.8^{*}$ & $66 \pm 4.1^{*}$ & $62 \pm 5.9^{*}$ \\
\hline HR & $87 \pm 47$ & $88 \pm 4.8$ & $92 \pm 5.0$ & $94 \pm 5.5$ & $91 \pm 4.2$ \\
\hline$n$ & 10 & 10 & 9 & 9 & 7 \\
\hline \multicolumn{6}{|c|}{ Solvent } \\
\hline $\operatorname{Min}$ & 0 & 5 & 1.5 & 30 & 60 \\
\hline SBP & $155 \pm 1.7$ & $153 \pm 2.3$ & $163 \pm 2.7$ & $154 \pm 12.2$ & $139 \pm 3.5$ \\
\hline DBP & $77 \pm 3.9$ & $77 \pm 4.1$ & $85 \pm 5.5$ & $91 \pm 5.8$ & $69 \pm 6.5$ \\
\hline$H R$ & $91 \pm 3.6$ & $90 \pm 3.7$ & $93 \pm 4.1$ & $103 \pm 10.1$ & $106 \pm 9.5$ \\
\hline$n$ & 10 & 10 & 9 & 3 & 2 \\
\hline
\end{tabular}

$\mathrm{SBP}=$ systolic blood pressure $(\mathrm{mmHg}) ; \mathrm{DBP}=$ diastolic blood pressure $(\mathrm{rnmHg})$; $H R=$ heart rate (beats/min); $n=$ number of patients without required additional treatment; Min = interval following study medication (minutes).

All values are presented as mean \pm SEM.

* $=p<0.05$ (significant difference vs control vallue min $=0$ ) 
vent group SBP, DBP and HR did not significantly change, and at $60 \mathrm{~min}$ only 2 patients were left in the study group because of the required additional treatment (nitroglycerin). Statistical analysis between the groups was only performed after 5 and 15 minutes because of the limited number of patients still included in the solvent group thereafter. At these intervals the difference between the effects of ketanserin and solvent was significant for systolic as well as diastolic blood pressure $(p<0.01)$. No significant differences in heart rate were observed between either group during the study period.

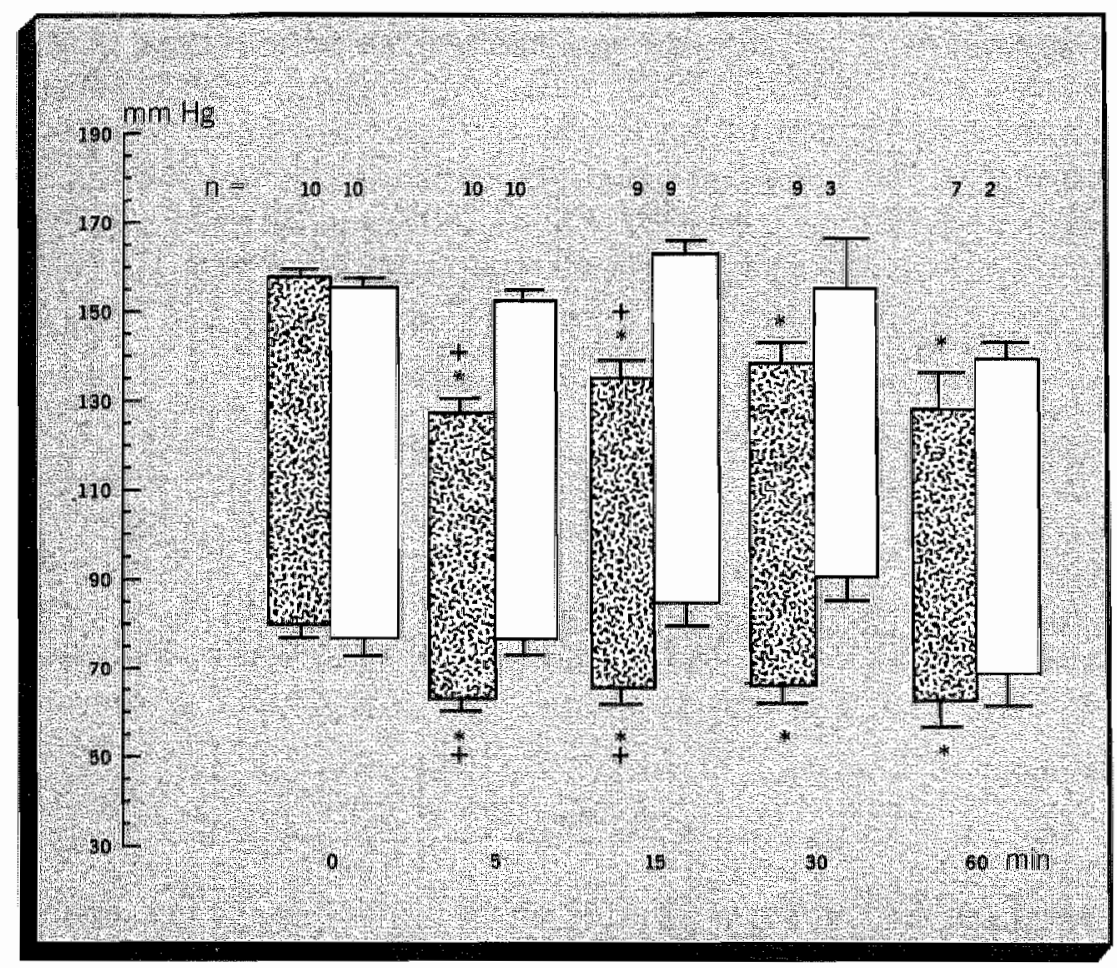

Fig 6.1

Graphic representation of systolic and diastolic blond pressure values ( \pm SEM) in the ketanserin ( $\mathrm{Ex}$ ) and solvent ( $\square$ ) group.

$*=p<0.05$ (significant difference us control value time $=0$ )

$t=p<0.01$ (significant difference between the groups) 


\section{Discussion}

The findings in this double blind study show that ketanserin is effective in lowering arterial blood pressure in patients with postoperative hypertension following $\mathrm{CABG}$, confirming previous findings in an open uncontrolled study (Van der Starre et al.1983).

The study design, in which strict linits were set for drop-outs because of the patients safety, confined the analysis period to 15 minutes because of the limited number of patients left in the solvent group thereafter. In concordance with the previous reports heart rate did not change significantly in the treatment group, as well as in the solvent group, suggesting in the first place that the patients were well sedated, relaxed and painfree, and in the second place that ketanserin might be able to block the barore-

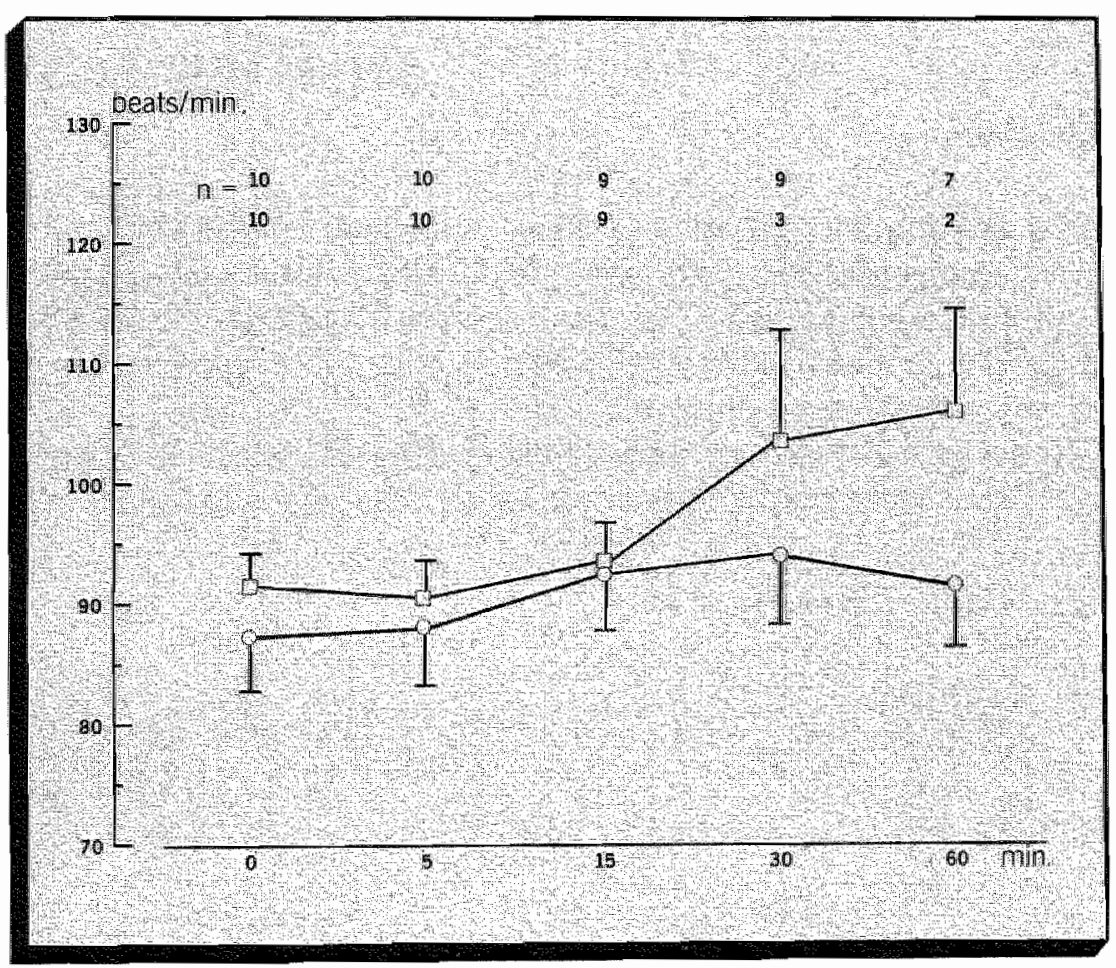

Fig 6.2

Graphic reresentation of changes in heart rale $( \pm$ SEM) in the ketanserin (O) and solvent group ( $\square$ ). 
ceptor response to a reduction in blood pressure, suggesting a centrally mediated mode of action, in addition to its $\mathrm{S}_{2}$-serotonergic and alpha $a_{1}$-adrenergic receptor blocking activity.

The role of serotonin in this type of hypertension is not well defined. It may be released from platelets, aggregating during uncontrolled suction and recirculation in the course of cardiopulmonary bypass (Wenzel et al.1979). It has also been suggested that heparin and protamin both can induce platelet aggegation ( Eika 1972, Zucker 1974).

The treatment of this clinical syndrome consists mainly of the use of vasodilating agents like nitroprusside, nitroglycerin, trimetaphan or hydralazin (Stinson et al 1975). This study proved that ketanserin is equally effective in the treatment of this form of hypertension during at least $30 \mathrm{~min}$ when used as a bolus injection, with the advantage that it does not induce a reflex tachycardia, which is often seen with the other antihypertensive agents agents (Mehta et al 1978, Tinker and Michenfelder 1976).

\section{Summary}

In two groups of 10 patients developing postoperative hypertension following coronary artery bypass grafting, a double blind study was designed to verify the efficacy of $10 \mathrm{mg}$ ketanserin, a $\mathrm{S}_{2}$-serotonergic receptor blocking compound with $\alpha_{1}$-adrenergic receptor blocking properties, in lowering arterial blood pressure.

The results of the study show that ketanserin was effective in significantly lowering arterial blood pressure, without causing reflex tachycardia. 


\section{Chapter 7}

Nitroprusside and ketanserin in the treatment of postoperative hypertension following coronary artery bypass grafting: a haemodynamic and ventilatory comparison 


\section{Introduction}

Hypertension following coronary artery bypass grafting is a frequent complication in the intensive care unit, reported to occur in 30-60\% of cases (Estafanous and Tarazi 1980, Roberts et al.1977). A rise in systemic vascular resistance is generally responsible for the rise in blood pressure in these patients, caused by changes in catecholamines, temperature and haemodilution (Wallard et al.1980, Taylor et all. 1977). Since the condition might lead to a rise in oxygen consumption, which is unwanted, treatment consists mainly of vasodilating agents, mostly nitroprusside (Tinker and Michenfelder 1976).

In earlier reports ketanserin, a specific $S_{2}$-serotonergic receptor antagonist with possible alpha-receptor blocking properties was effective in the treatment of this clinical syndrome (Van der Starre et al.1983). In this study nitroprusside and ketanserin were compared in this respect by measuring changes in haemodynamic and ventilatory patterns.

\section{Materials and methods}

Twenty patients who developed hypertension (systolic blood pressure higher than $150 \mathrm{mmHg}$ ) following coronary artery bypass grafting were randomly treated with either ketanserin (10 patients) of nitroprusside ( 10 patients). All patients were treated with long-acting nitrates, calcium channel blockers and beta-blockers until the morning of surgery. None of the patients had a concomitant disease or impaired left ventricular function. Premedication consisted of scopolamin $0.005 \mathrm{mg} / \mathrm{kg}$ and morphine $0.15 \mathrm{mg} / \mathrm{kg} 1 \mathrm{~h}$ before surgery and general anesthesia of intravenous anesthetics (fentanyl, benzodiazepines) and relaxants (pancuronium). Mechanical ventillation was applied with $\mathrm{F}_{1} \mathrm{O}_{2}=0.6$. The anesthetical and surgical procedure were standardized, as was the extracorporeal circulation (chapter 3.3).

The aim of the study was to lower systolic blood pressure by $10-15 \%$ with either agent and to study other haemodynamic and ventilatory variables. To achieve this effect, the ketanserin dose administered was $10 \mathrm{mg}$ bolus, followed by $0.13 \pm 11 \mathrm{mg} / \mathrm{kg}$ per h. For nitroprusside the dose administered was $6.0 \pm 0.3 \mu \mathrm{g} / \mathrm{kg}$ per min.

All patients were mechanically ventilated, aiming at a $\mathrm{pCO}_{2}$ of $45 \mathrm{mmHg}$ and $\mathrm{pO}_{2}$ higher than $100 \mathrm{mmHg}$, sedated and relaxed if necessary. All patients had intra-arterial blood pressure monitoring in a radial artery, a Swan-Ganz catheter in the pulmonary artery to allow thermodilution cardiac output measurements and the electrocardiogram (lead II and $V_{5}$ ) and heart rate were continuously monitored ( chapter 3.1). 
The following variables were measured before and $30 \mathrm{~min}$ after the start of either therapy: systolic blood pressure (SBP), diastolic blood pressure (DBP), heart rate (HR), systemic vascular resistance (SVR), cardiac index $(\mathrm{Cl})$, central venous pressure (CVP), systolic pulmonary artery pressure (SPAP), diastolic pulmonary artery pressure (DPAP), pulmonary capillary wedge pressure (PCWP) and pulmonary vascular resistance (PVR).

In addition the shunt fraction (Qs/Qt) was calculated (Conroe et al.1968), for which reason the patients were ventilated for 5 min before measurement with 100\% oxygen.

Statistical analysis was performed using the Wilcoxon matched-pairs signed-ranks test for intragroup differences and the Mann-Whitney U-test for intergroup differences. Differences were considered to be significant when $p<0.05$.

\section{Results}

The results are summarized in Table 1 , which shows that the two study

\begin{tabular}{|c|c|c|c|}
\hline & $\begin{array}{l}\text { Ketanserin } \\
\text { group }\end{array}$ & $\begin{array}{l}\text { Nitroprusside } \\
\text { group }\end{array}$ & Units \\
\hline SBP & $-21.1 \pm 6.6$ & $-19.1 \pm 1.6$ & $\mathrm{mmHg}$ \\
\hline DBP & $-5.7 \pm 1.9$ & $-6.9 \pm 1.7$ & $\mathrm{mmHg}$ \\
\hline CVP & $=1.1 \pm 0.02$ & $-0.8 \pm 0.01$ & $\mathrm{minHg}$ \\
\hline PCWP & $-2.5 \pm 0.25$ & $-1.8 \pm 0.15$ & $\mathrm{mmHg}$ \\
\hline $\mathrm{Cl}$ & $+0.3 \pm 0.06$ & $+0.4 \pm 0.08$ & $1 / \mathrm{minh} / \mathrm{m}^{2}$ \\
\hline SPAP & $-2.2 \pm 0.8$ & $-3.3 \pm 1.6$ & $\mathrm{mmHg}$ \\
\hline DPAP & $-3.3 \pm 1.0$ & $-3.2 \pm 0.7$ & $\mathrm{~mm} H \mathrm{Hg}$ \\
\hline SVR & $-208 \pm 83.0$ & $-424 \pm 680$ & dyn.s/cm $\mathrm{cm}^{5}$ \\
\hline PVR & $-54 \pm 17.0$ & $-48 \quad \pm 12.1$ & $\mathrm{dyn} . \mathrm{s} / \mathrm{cm}^{5}$ \\
\hline HR & $-0.1 \pm 1.2$ & $+15.2 \pm 3.5 *$ & beats/min \\
\hline Qs/Qt & $-0.85 \pm 0.72$ & * 9.99 业 $1.44^{*}$ & $\%$ \\
\hline
\end{tabular}

$\mathrm{SBP}=$ systolic blood pressure $\mathrm{DBP}=$ diastolic blood pressure; $\mathrm{CVP}=$ central venous pressure; $P C W P=$ pulmonary capillary wedge pressure; $C l=$ cardiac index; $S P A P=$ systolic pulmonary artery pressure; DPAP = diastolic pulmonary artery pressure; SVR $=$ systemic vascular resistance; $P V R=$ pulmonary vascular resistance; $H R=$ heart rate: $Q s / Q t=$ shunt fraction.

* $=\mathrm{p}<0.05$ (significant difference between the groups) 
Fig. 7.1.
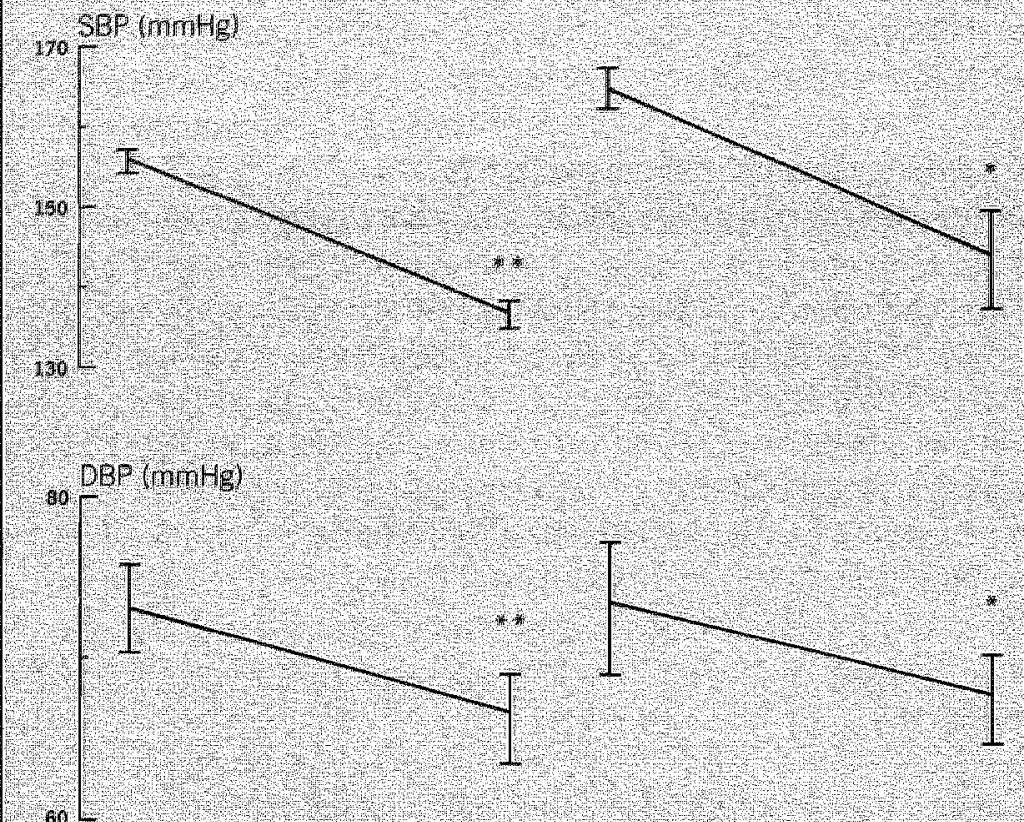

601
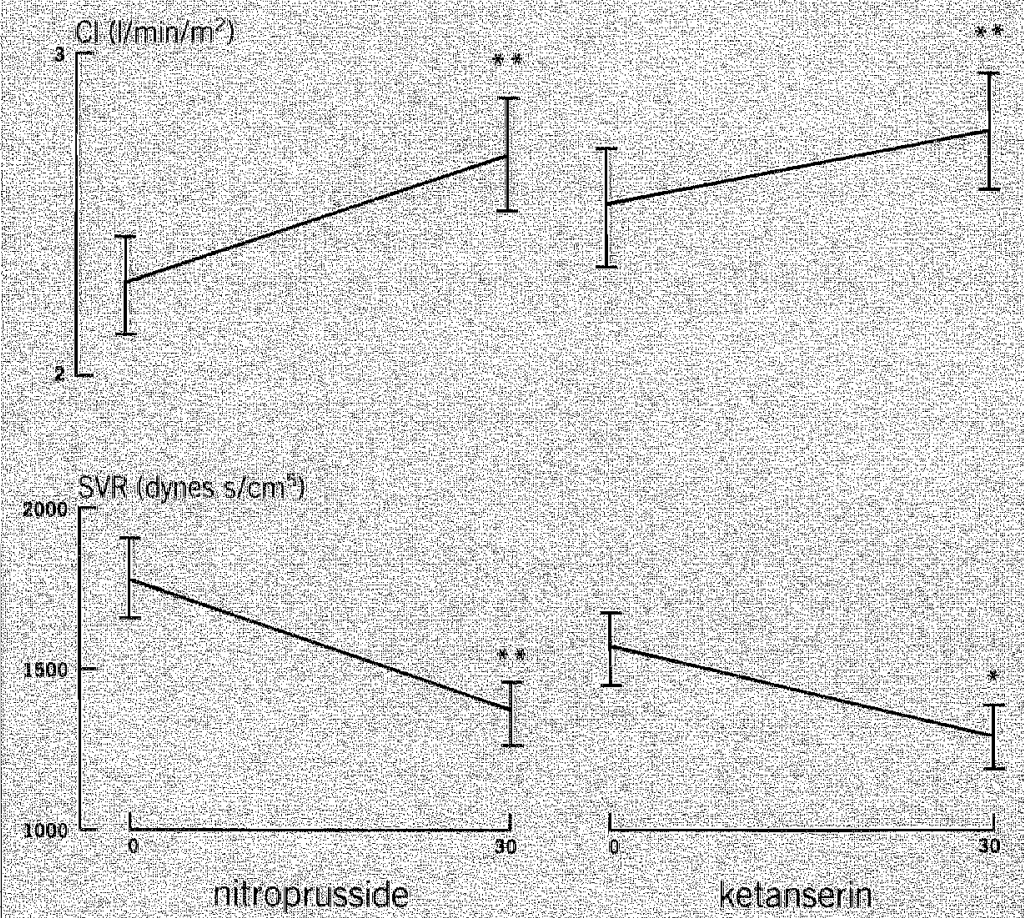
groups were comparable in age, weight, sex, systolic blood pressure and iength of time elapsed after surgery before start of treatment. The effect of ketanserin and nitroprusside on the various measurements are shown in Figs 1 and 2. There appeared to be no significantly different changes between the two groups with respect to changes in SBP, DBP, CVP, PCWP, $\mathrm{Cl}$, SPAP, DPAP, SVR, and PVR.

Heart rate did not change in the ketanserin group $(-0.1 \pm 1.2$ beats/ $\mathrm{min})$. but increased in the nitroprusside group ( $+15.2 \pm 3.5$ beats/min)。 causing a significant difference between the two study groups.

The shunt fraction (Qs/Qt) did not change significantly in the ketanserin group $(-0.85 \pm 0.72 \%)$, but increased in the nitroprusside group $(+9.99 \pm$ $1.44 \%$ ), causing a significant difference between the two groups as well. The individual patient data with respect to changes in the heart rate and shunt fraction are shown on Figs 3 and 4.

\section{Discussion}

Hypertension following coronary artery bypass grafting, consisting mainly of an increase in systolic blood pressure, is a main issue for treatment in the intensive care unit. Studies report a 30-60\% incidence of hypertension for patients in the first postoperative hours (Estafanous and Tarazi 1980, Roberts et al. 1977). Bacause the operation uses hypothermic extracorporeal circulation circulation, changes occur in catecholamines, renim, angiotensin and possibly serotonin levels (Wallard et al. 1980, Taylor et al. 1977, Stinson et al. 1975). This occurs in parallel with changes in the degree of haemodilution. Generally, temperature rises gradually during this period. All these phenomena together can lead to postoperative hypertension, mainly caused by an increase in systemic vascular resistance (Estafanous and Tarazi 1980, Roberts et al. 1977, Wallard et al. 1980).

Treatment consists of the use of vasodilating agents, such as nitroprusside, nitroglycerin, hydralazine and trimetaphan (Tinker and Michenfelder

\section{Fig.7.1.}

Changes in systolic blood pressure (SBP), diastolic blood pressure (DBP), cardiac index (Cl) and systemic vascular resistance $\left(S V R\right.$, dynes. $\left./ / \mathrm{cm}^{5}\right)$ in both groups.

* $=p<0.05$ (significantly different from control value)

$*=p<0.01$ (significantly different from controll value)

There was mo significant difference between the groups with respect to these changes. 
Fig. 7.2

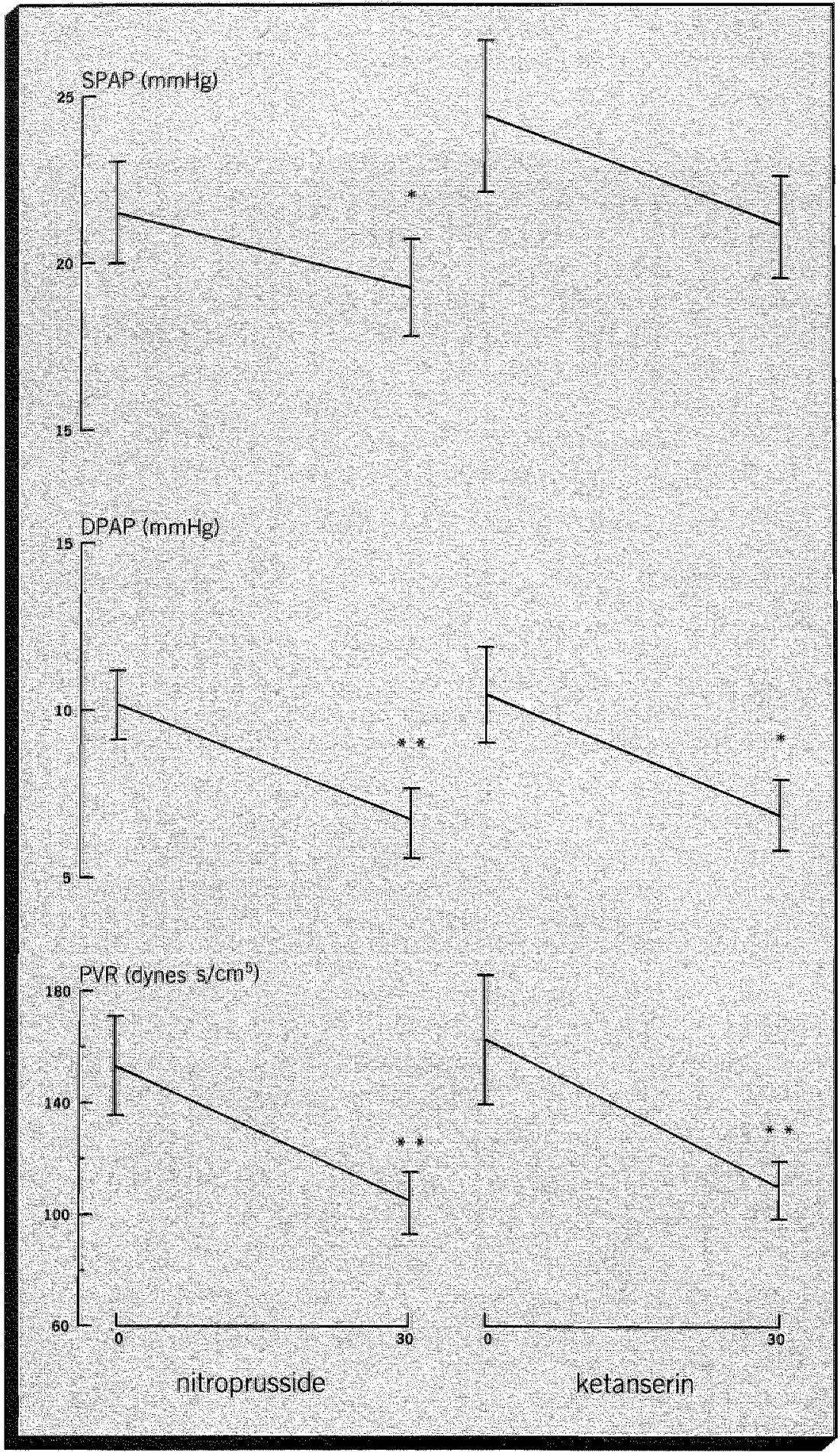


1976, Stinson et al. 1975). Earlier reports have shown that ketanserin is effective in the treatment of postoperative hypertension, with the advantage of an absence of reflex tachycardia (Van der Starre et al, 1983). This study, comparing nitroprusside and ketanserin, showed a statistically significant difference between the two groups with respect to changes in the heart rate and shunt fraction. Since all patients had coronary artery disease and one is never certain that revascularization has been successful in the early postoperative period, a refiex tachycardia can lead to an unwanted rise in myocardial oxygen consumption, with the possibility of ischaemia. In this respect ketanserin might be advantageous compared with nitroprusside, especially in patients who have already developed tachycardia postoperatively. Most patients develop an increase in lung water postoperatively following extracorporeal circulation, due to changes in water content and colloid osmotic pressure pre-and postoperatively (Shivah et al. 1982). This can lead to a rise in shunt fraction, followed by an impairment of oxygenation and ventilation. In agreement with earlier reports, in which nitroprusside caused hypoxia (Seltzer et al. 1976), this study showed the effect of both agents on the shunt fraction and proved that ketanserin was advatageous, especially in patients who already have increased lung water such as patients with pre-operative heart failure. Apparently, ketanserin did not abolish the hypoxic pulmonary vasoconstriction as nitroprusside did in other patients (D'Oliviera et al.1981).

This study indicates that ketanserin and nitroprusside are equally effective in the treatment of postoperative hypertension following coronary artery bypass grafting, but ketanserin might be advantageous in patients with already existing tachycardia, or with impaired oxygenation and ventilation, due to an increased shunt fraction.

Fig. 7.2

Changes in systolic puimonary artery pressure (SPAP), diastolic pulmonary artery pressure (DPAP) and pulmonary vascular resistance (PVR, dynes.5/cm $)$ in both groups.

* $=p<0.05$ (significantly different from control value)

* $=0.01$ (significantly different from control value)

There was no significant difference between the groups with respect to these changes. 
Fig. 7.3

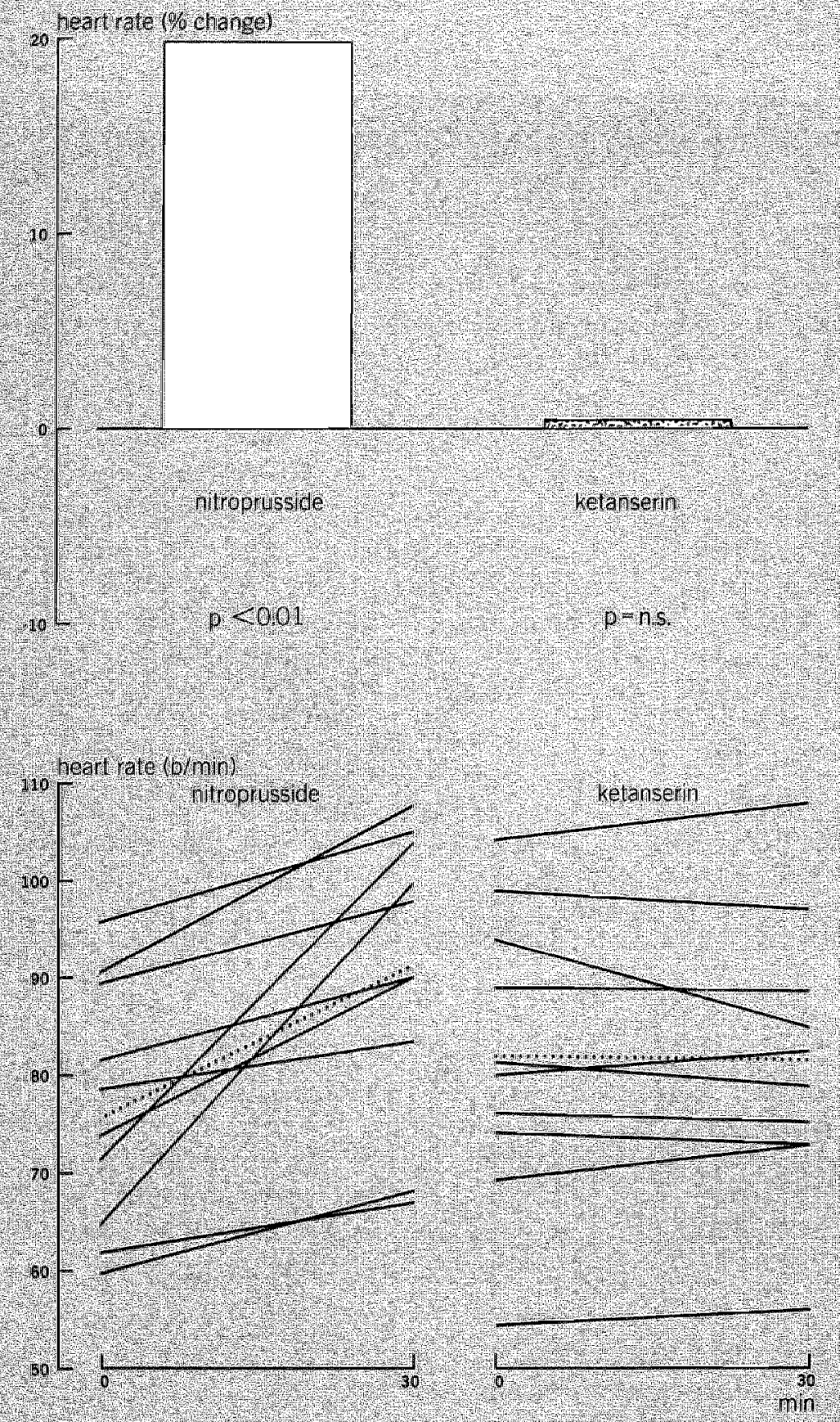




\section{Fig. 7.3 .}

Upper panel: changes in heart rate in both groups (intragroup). There was a significant difference $(p<0.01)$ in these changes between the groups.

Lower panel: individual patient data $(-$ with mean value $(\cdots .$.$) are depicted for both$ groups. 


\section{Summary}

Postoperative hypertension following coronary artery bypass grafting is usually treated with vasodilating agents like nitroprusside. In recent studies ketanserin, a $S_{2}$-serotonergic receptor antagonist, appeared to be effective in the treatment of this clinical syndrome. In 20 patients, divided into two comparable groups, nitroprusside and ketanserin were compared with respect to their haemodynamic and ventilatory profiles. The study showed that both agents were equally effective in decreasing the raised systolic blood pressure, but that ketanserin was more advantageous with respect to the absence of reflex tachycardia and the unchanged shunt fraction.

Fig. 7.4.

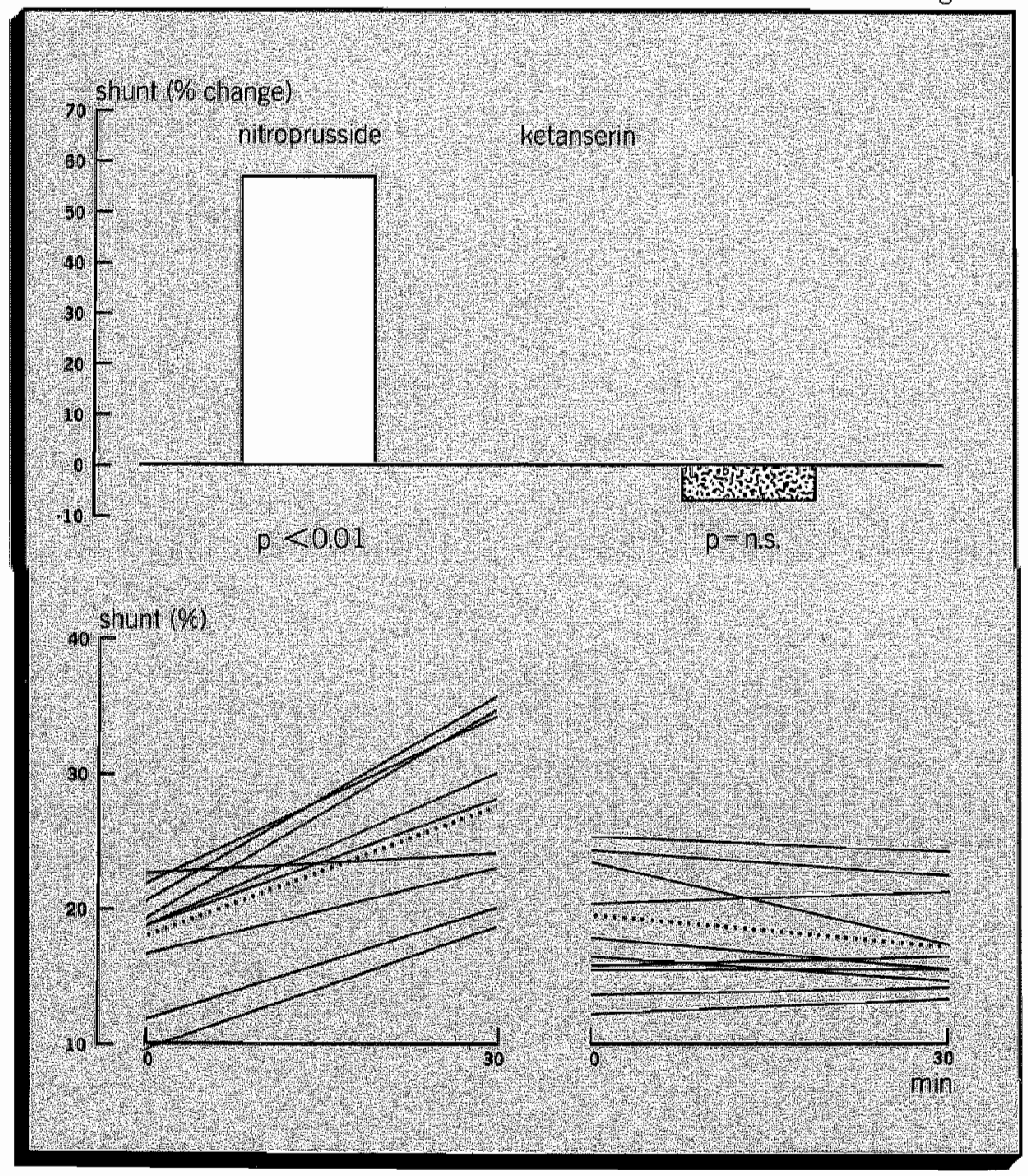


Legend to Fig.7.4.

Upper panel: changes in shunt fraction (Qs/Qt) in both groups. There was a significant difference $(p<0.01)$ in these changes between the groups.

Lower panel: individual patient data $(-)$ with mean value $(\cdots .$.$) are depicted for both$ groups. 
Chapter 8

Ketanserin in the treatment of pulmonary hypertension following valvular surgery: a comparison with sodium nitroprusside 


\section{Introduction}

In patients with valvular heart disease the gradual impairment of left ventricular function causes puimonary venous congestion and hypertrophic changes of the vessel walls leading to an increase in pulmonary vascular resistance and ultimately to pulmonary hypertension (Rounds and Hill 1984, Reid 1986). In these patients the pulmonary ventilation-perfusion ratio is significantly altered (Cortese 1978, Laver et al.1970, Anjou-Lindskog et al.1983) while the extravascular water content of the lungs is higher than in normal subjects (Laver et al.1970), causing a reduction in lung compliance and functional residual capacity (FRC) and an increase in residual volume (Hinds 1982). These patients are usually treated with diuretics, digoxine and vasodilating agents, like hydralazin, nitroglycerin, angiotensin converting enzyme inhibitors and calcium entry blockers, but these compounds are not able to normalize pulmonary arterial pressure (Bolen and Alderman 1976, Cohn and Franciosa 1977, Kopman 1979). Recurrent episodes of congestive heart failure, sometimes with severe pulmonary oedema, and serious impairment of the physical condition of the patient determine the indication for valvular surgery (Bonchek 1980, Hancock 1977, Pluth and Ellis 1969).

During surgery lung function further deteriorates because general anesthesia reduces FRC (Marshall and Wyche 1972, Rehder et al.1975, Ali et al.1974, Jonmarker et al.1986) while during cardiopulmonary bypass (CPB) extra-vascular lung water content increases (Boldt et al.1986, Sade et al.1985, Gallagher 1985) as a consequence of complement activation (Chenoweth et al.1981, Best et al.1984, Jones et al.1982, Cavarocchi et all.1986) causing increased permeability of the pulmonary capillary membranes (Kirklin et al.1986, Miranda et al.1982, Jones et al.1.986). In these conditions substantial pulmonary hypertension in the early postoperative period leads to pulmonary oedema (Sniderman et al.1984) and right ventricular failure (Kaul et al.1976, Christakis et al.1986). Atelectasis, the most common pulmonary complication, is reported in 60 to $80 \%$ of these patients (Gale et al.1979, Tumbull et al.1974).

Vasodilating agents like hydralazin (Sladen and Rosenthal 1979. Packer et al.1982), prostacyclin (D'Ambra et al.1985), nitroglycerin (Goenen et al.1982, Rosenthal et al.1981) and sodium nitroprusside (Knapp and Gmeiner 1977) are frequently used to reduce pulmonary arterial pressure in the postoperative period, but an increase in pulmonary shunt fraction is one of the main side effects of these compounds (Parsons et al.1981, D'Oliviera et al.1981).

Ketanserin, a $S_{2}$-serotonergic receptor antagonist with $\alpha_{1}$-adrenergic receptor blocking properties, has been reported to reduce pulmonary vas- 
cular resistance in patients with acute respiratory failure (Huval et al.1984) and to improve pulmonary circulation in endotoxic shock (Meuleman et al.1983, Huval et al.1983, Vincent et al.1984, Koyama et al. 1985 , Hechtman and Sherpo 1984).

It was the aim of the present prospective study to compare postoperatively the effects of ketanserin and sodium nitroprusside on pulmonary artery pressure, systemic haemodynamics and pulmonary shunt fraction in patients who underwent valvular surgery. The compounds were administered when pulmonary arterial pressure increased and cardiac output started to decrease.

\section{Materials and methods}

The study was performed on patients admitted to the ICU following surgery for single or double valvular replacement or annuloplasty. All patients were mechanically ventilated, aiming at a $\mathrm{pCO}_{2}$ of $45 \mathrm{mmHg}$ and a $\mathrm{pO}_{2}$ between 100 and $150 \mathrm{mmHg}$. A positive end-expiratory pressure (PEEP) of $5 \mathrm{~cm} \mathrm{H}_{2} \mathrm{O}$ was applied. The patients received fluids at a rate of $1.5 \mathrm{ml} /$ $\mathrm{kg} / \mathrm{hr}$, iritially consisting of residual priming from the oxygenator and later of Ringer's lactate with dextrose $5 \%$. If the colloid osmotic pressure, measured with the use of a membrane-transducer ancometer (Barclay and Bennett 1987), was lower than $16 \mathrm{mmHg}, 100 \mathrm{ml}$ of albumin 20\% was slowly infused. Routinely temporary pacing wires were sutured on the epicardium before weaning of CPB. All patients were treated with a continuous infusion of dopamine, dobutamine or a combination of these agents, which was started in the operating room during weaning from $C P B$, to improve myocardial performance and consequently cardiac output. No other vasodilating or inotropic agents were administered during the study period.

All patients had a radial artery cannula. A Swan-Ganz thermodilution catheter was inserted before surgery into the pulmonary artery via an internal jugular or subclavian vein. ECG (lead II and $V_{5}$ ), heart rate (HR, assessed from the ECG), systolic (SBP), diastolic (DBP) and mean (MAP) arterial pressure, systolic (SPAP), diastolic (DPAP) and mean (MPAP) pulmonary arterial pressure, central venous pressure (CVP), pulmonary capillary wedge pressure (PCWP) as well as rectal and peripheral temperature were monitored and recorded. Cardiac output $(\mathrm{CO})$ was measured using the thermodilution technique (76). Systemic (SVR) and pulmonary (PVR) vascular resistance, left (LVSW) and right ventricular stroke work (RVSW) were calculated using the following equations: 
SVR $=\frac{\text { MAP.CVP } \times 80}{C O}$ dyn.S. $\mathrm{cm}^{-5}$

$P V R=\frac{\text { MAP } P C W P}{C O} \times 80$ dyn.. $\mathrm{cm}^{-5}$

$L V S W=\frac{136 \text { (MAP.PCWP) } \times \text { stroke volume [SW: }}{100} \mathrm{gm}$

RVSW $=\frac{1.36 \text { (MPAP.CVP) } \times \text { SW }}{100} \mathrm{gm}$

Shunt fraction (Qs/Qt) was determined after ventilating the patients with $100 \% \mathrm{O}_{2}$ during $5 \mathrm{~min}$, with the use of the following equation (Comroe et al.1968):

$\mathrm{QS} / \mathrm{QT}=\frac{\mathrm{Cc}_{\mathrm{O} 2}-\mathrm{Ca}_{\mathrm{O} 2}}{\mathrm{CC}_{\mathrm{O} 2}-\mathrm{Cv}_{\mathrm{O} 2}} \%$

in which $\mathrm{CC}_{\mathrm{O} 2}=$ end-capillary oxygen content; $\mathrm{Ca}_{\mathrm{O} 2}=$ arterial oxygen content $\mathrm{Cv}_{02}=$ mixed venous oxygen content.

Immediately following admission to the ICU the values of the above mentioned variables and parameters were determined. When MPAP had increased more than $5 \mathrm{mmHg}$ and $\mathrm{CO}$ started to decrease, the patients were randomly treated with either sodium nitroprusside (SNP, $n=14$ ), starting with a dose of $1 \mu \mathrm{g} / \mathrm{kg} / \mathrm{min}$ or ketanserin (KET, $n=12$ ), starting with a dose of $1.7 \mu \mathrm{g} / \mathrm{kg} / \mathrm{min}$, with the intention to reduce MPAP to its early post-bypass value. The infusion rates of the study medication were adjusted according to the hemodynamic results. After 30 min of treatment the measurements and calculations were repeated. Ten patients in the SNP-group and 7 patients in the KET-group had a pacemaker-induced heart rate at the start of the study period.

All data are presented as mean $上$ SEM. Statistical analysis was performed with the use of the Wilcoxon signed-rank test for intragroup comparison, and the Mann-Whitney U-test for comparison between the groups. A propability level of $p<0.05$ was considered to indicate statistical significance.

\section{Results}

The two study groups were comparable with regard to type of surgery and the postoperative use of inotropic agents (dopamine and dobutamine) (Tables 1 and 2). There was no significant difference in age (SNP-group 61 \pm 6.6 yrs, KET-group $58 \pm 1.8 \mathrm{yrs}$ ) and weight (SNP-group $67 \pm 8.1 \mathrm{~kg}$, KET-group $69 \pm 2.6 \mathrm{~kg}$ ) between the groups. The preoperative values of 


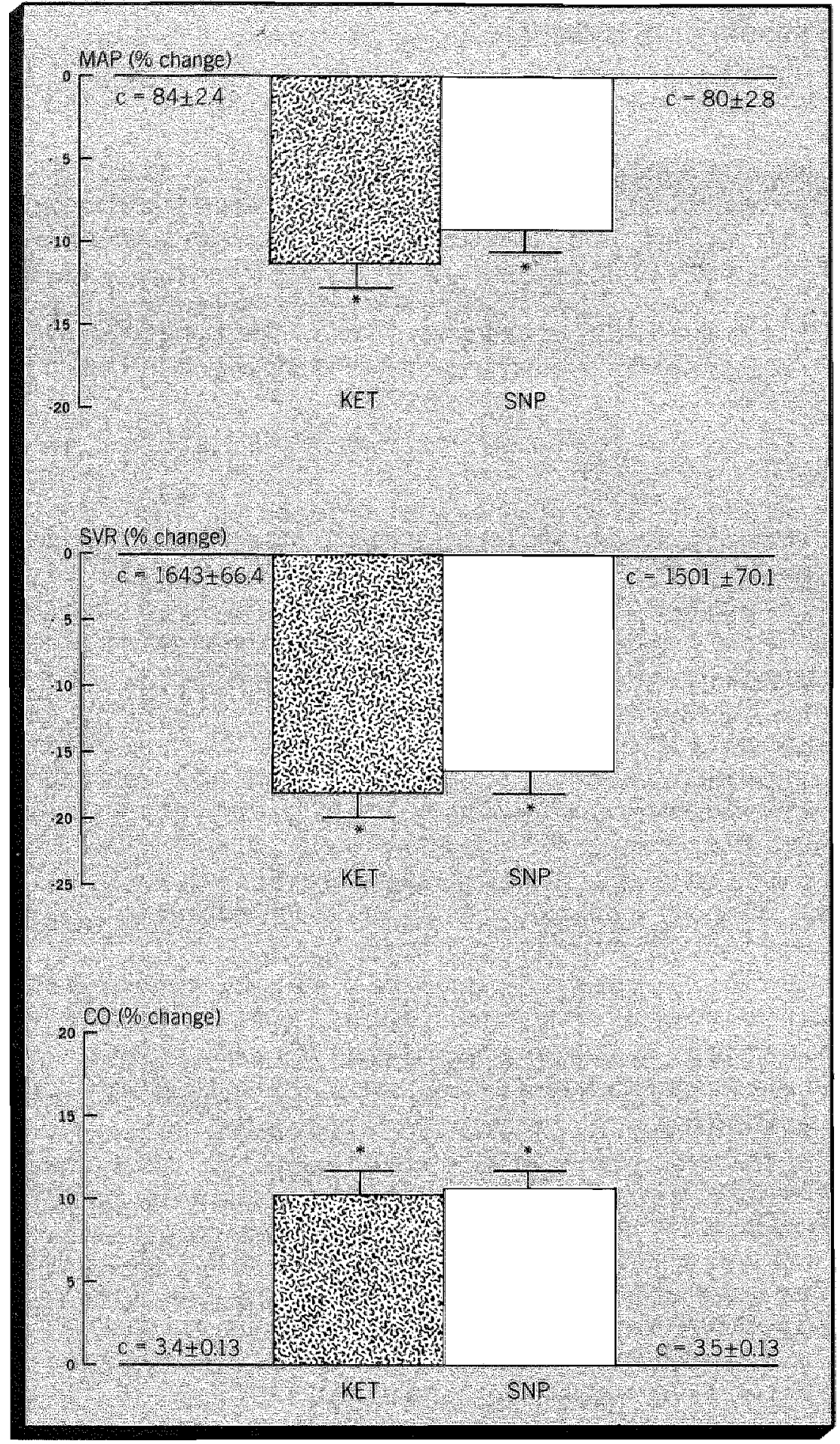




\begin{tabular}{|c|c|c|c|c|c|}
\hline No. & $\begin{array}{c}\text { Preoperative } \\
\text { Diagnosis }\end{array}$ & $\begin{array}{c}\text { Concomitant } \\
\text { Disease }\end{array}$ & $\begin{array}{c}\text { Preoperative } \\
\text { PAP }\end{array}$ & Surgery & $\begin{array}{c}\text { Postoperative } \\
\text { motropics }\end{array}$ \\
\hline 1 & MS & DM! & $60 / 32$ & MVR & dopa \\
\hline 2 & $\mathrm{Al}$ & - & $65 / 31$ & AVR & dobut \\
\hline 3 & MS/MI & CAOD & $68 / 31$ & MWRAACB & dopa/dobut \\
\hline 4 & AS & CAOD & $58 / 28$ & AVR/ACB & dopa \\
\hline 5 & AS/AI & COPD & $60 / 30$ & AVR & dopa \\
\hline 6 & MI & DM & $7 / / 35$ & MVR & dobut \\
\hline 7 & $M I$ & - & $41 / 23$ & MPL & dopa \\
\hline 8 & $M U / T$ & RA & $68 / 35$ & MWRTPL & dopa/dobut \\
\hline 9 & MII & $\infty$ & $60 / 30$ & MVR & dopa \\
\hline 10 & $\mathrm{AS} / \mathrm{Al}$ & - & $65 / 35$ & AvR & dopa \\
\hline 11 & Al/MI & - & $58 / 29$ & AVR/AVR & dopa/dobut \\
\hline 12 & MS & COPD & 56125 & MVR & dobut \\
\hline
\end{tabular}

$P A P=$ pulmonary arterial pressure; $A l=$ aortic insufficiency; $A S=$ aortic stenosis;

$M I=$ mitral insutficiency; $M S$ - mitral stenosis; $T=$ tricuspid insufficiency;

$\mathrm{CAOD}=$ coronary artery ooclusive disease $\mathrm{COPD}=$ chranic obstructive pulmonary disease; $D M=$ diabetes mellitus; $\mathbb{R A}=$ rheumatic arthritis;

$A V R=$ aortic walve replacement; $M V R=$ mitral valve replacement; $T P L=$ tricuspid valve plasty: $M P L=$ mitral valve plasty; $A C B=$ arorto-coronary bypass; dopa= dopamine;

dobut = clobutamine.

SPAP, DPAP, MPAP and PVR were significantly higher $(p<0.05)$ in the KET-group.

During the study period in both groups MAP (fig 1), SVR (fig 1), MPAP'fig 2), PVR (fig 2), RVSW (fig 2), and SBP, DBP, SPAP, DPAP, CVP and PCWP (data not depicted) significantly decreased, whereas CO (fig 1 ) significantly increased. The decrease in MPAP $(p<0.01)$, PVR $(p<0.01)$ and RVSW ( $p<0.05$ ) was significantly more pronounced in the KET- than in the SNP-group (fig 2). LVSW did not change significantly in the SNPand KET-groups. Qs/Qt significantly increased $(p<0.001)$ in the SNP-

Fig.8.

Changes in mean arterial pressure; cardiac output and systemic vascular resistance and control values (c) in the ketanserin (KET) and sodium nitroprusside (SNP)-group (mean \pm SEM).

* $=0<0.001$ (significantly different from $c$ ) 
Fig. 8.2 .

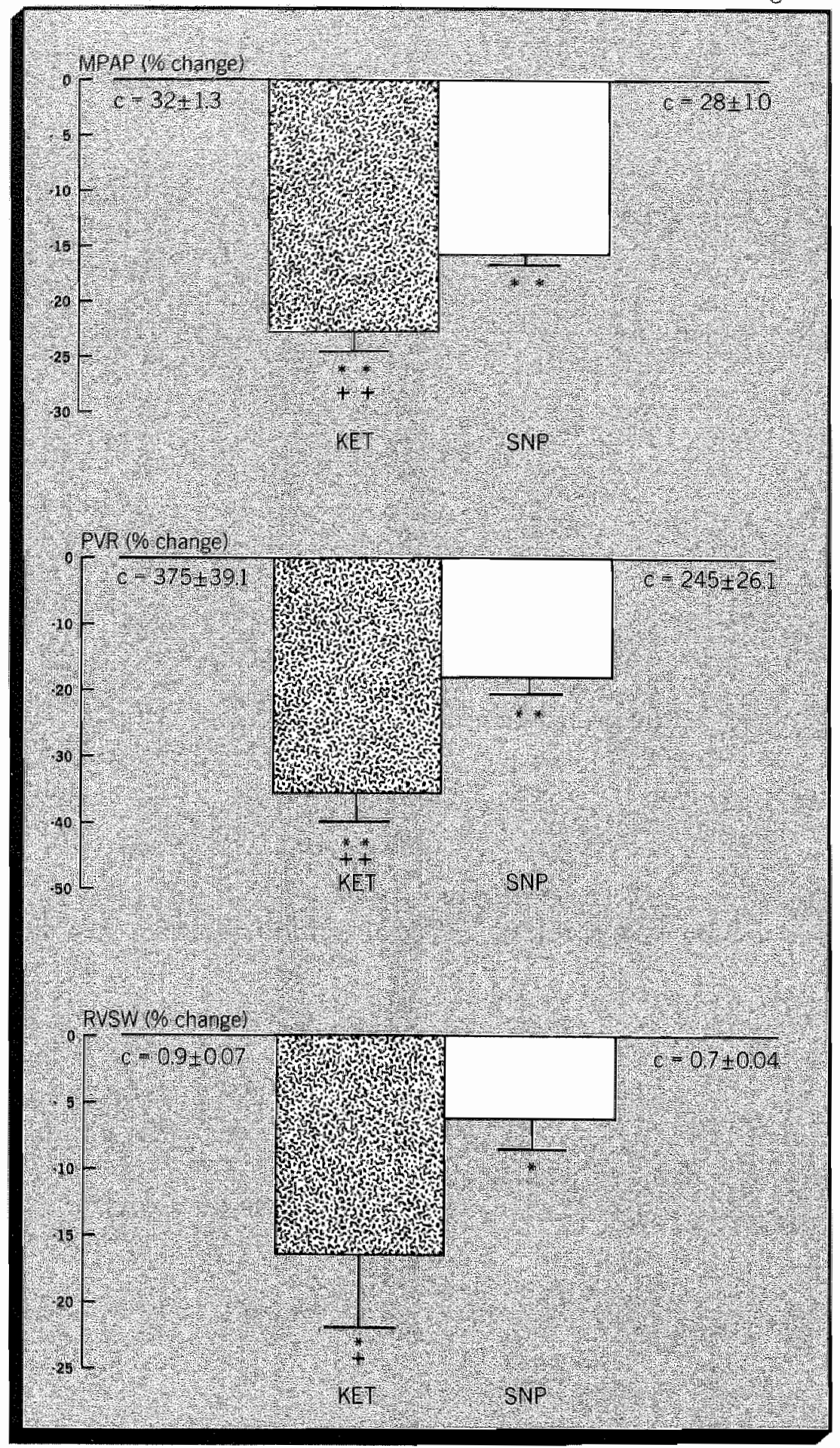




\begin{tabular}{|c|c|c|c|c|c|}
\hline No. & $\begin{array}{c}\text { Preoperative } \\
\text { Diagnosis }\end{array}$ & $\begin{array}{c}\text { Concomitant } \\
\text { Disease }\end{array}$ & $\begin{array}{c}\text { Preoperative } \\
\text { PAP }\end{array}$ & Surgery & $\begin{array}{c}\text { Postoperative } \\
\text { Inotropics }\end{array}$ \\
\hline 13 & Al & CAOD & $58 / 34$ & AVRIACB & dopa \\
\hline 14 & MS & DM & $55 / 21$ & MVR & dobut \\
\hline 15 & $\mathrm{MI}$ & - & $60 / 22$ & MVR & dopa \\
\hline 16 & $\mathrm{Al} / \mathrm{MI}$ & COPD & 56124 & AVR/MVR & dopa/dobut \\
\hline 17 & MU/TI & - & $65 / 28$ & MVR/TPL & dopa \\
\hline 18 & AS/AI & DM & $51 / 24$ & AVR & dobut \\
\hline 19 & $\mathrm{Al}$ & - & $38 / 20$ & $A V R$ & dobut \\
\hline 20 & MI &. & $51 / 22$ & MVR & dopa \\
\hline 21 & MI & DM & $40 / 20$ & MVR & dopa/dobut \\
\hline 22 & AS & DM & $48 / 24$ & AVR & dobut \\
\hline 23 & MS & COPD & $58 / 24$ & MVR & dopa \\
\hline 24 & MSIMI & - & $65 / 30$ & MVR & dopa/dobut \\
\hline 25 & $\mathrm{Al} / \mathrm{MI}$ & - & $71 / 32$ & AVR/MVR & dopa/dobut \\
\hline 26 & AS & CAOD & $48 / 20$ & AVR/ACB & dopa \\
\hline
\end{tabular}

For clarification of abbreviations see table 1 .

group and significantly decreased ( $p<0.05$ ) in the KET-group (fig 3); a significantly different change in shunt fraction between the two groups ( $p<0.001$ ). In 6 patients in the SNP-group pacemaker-induced heart rate converted into a form of spontaneous rhythm (sinus rhythm or atrial fibrillation). This was observed in only 1 patient (sinus rhythm) in the KETgroup.

The mean infusion rate in the SNP-group was $0.15 \pm 0.03 \mu \mathrm{g} / \mathrm{kg} / \mathrm{min}$ sodium nitroprusside, and in the KET-group $2.33 \pm 0.91 \mu \mathrm{g} / \mathrm{kg} / \mathrm{min} \mathrm{ke}-$ tanserin. Apart from the routine protocol no additional fluids were administered during the study period.

\section{Fig.8.2:}

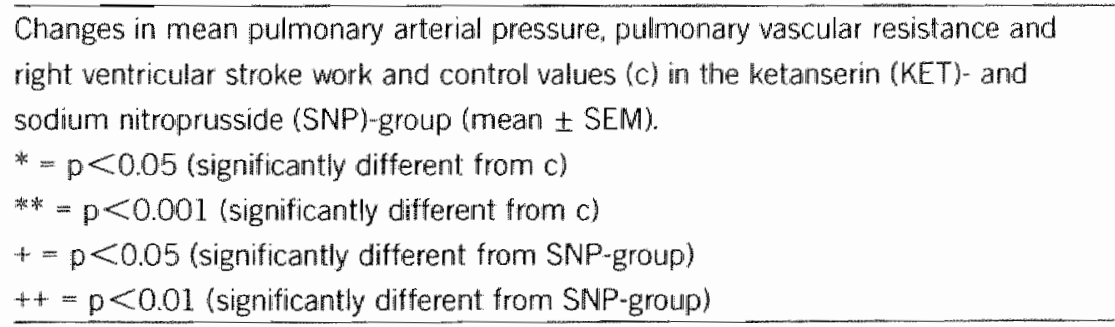




\section{Discussion}

The findings in this study demonstrate that both ketanserin, a specific $\mathrm{S}_{2}$ serotonergic receptor antagonist with $\alpha_{1}$-adrenergic receptor blocking properties, and sodium nitroprusside are able to reduce pulmonary hypertension, by decreasing pulmonary vascular resistance, in patients undergoing valvular surgery. In this respect, at the dose levels used ketanserin is more effective, resulting in a more pronounced reduction in right ventricular work following the administration of this compound. In contrast to ketanserin, sodium nitroprusside causes a significant increase in pulmonary

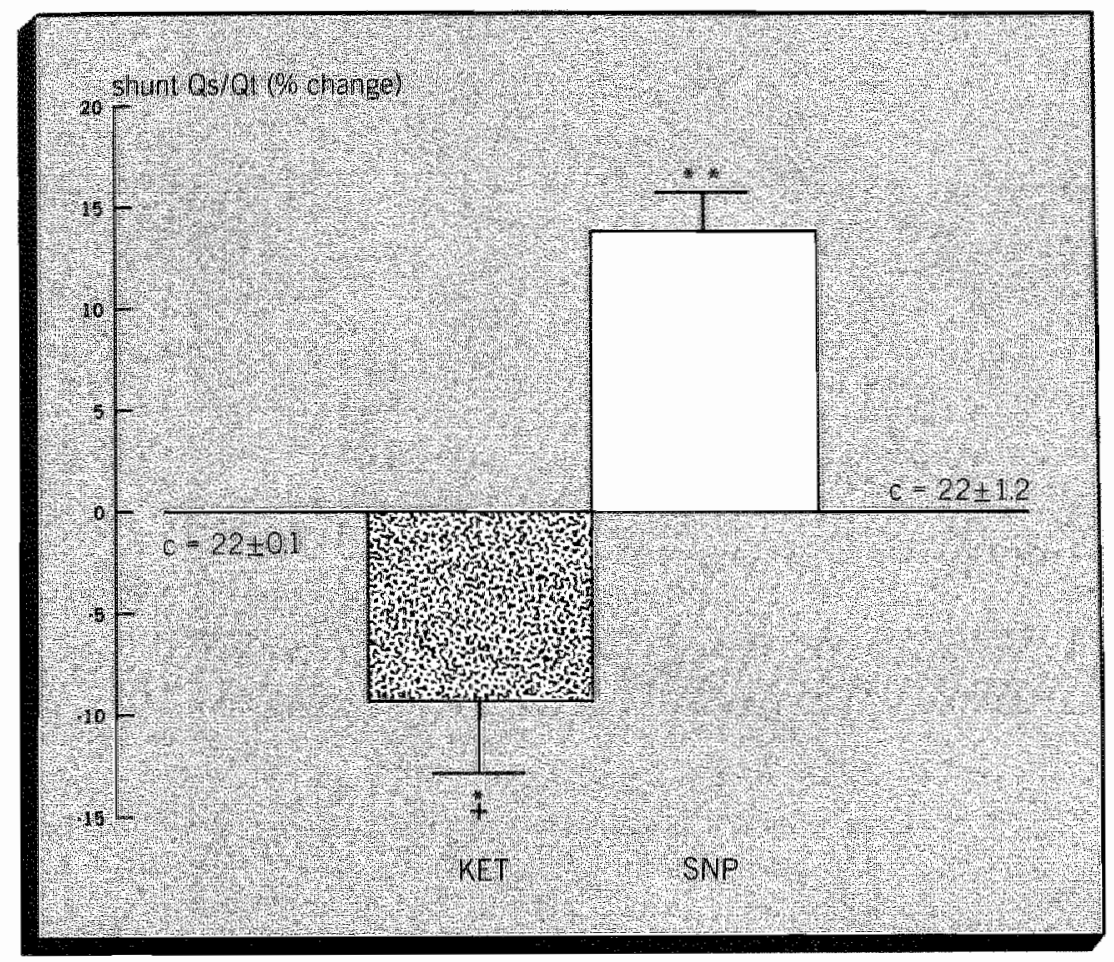

Fig.8.3:

Changes in pulmonary shunt fraction (Qs/Qt) and control values (c) in the ketanserin (KET)- and sodium nitroprusside (SNP)-group (mean \pm SEM).

$*: p<0.05$ (significantly different from $c$ )

$* *=0<0.001$ (significantly different from c)

$+=p<0.001$ (significantly different from SNP-group) 
shunt fraction. This finding is in accordance with the results of a previous. study performed in patients with normal pulmonary arterial pressure following coronary artery bypass surgery (Van der Starre et al.1986)

From earlier studies it is known that sodium nitroprusside and nitroglycerin may cause hypoxemia by increasing pulmonary shunt fraction (Parsons et al.1981, D'Oliviera et al.1981). Although an increase in shunt fraction might be explained by an increase in cardiac output (Lynch et al.1979), the different influence of both compounds on shunt fraction at similar cardiac output levels suggests that ketanserin, as opposed to sodium nitroprusside, does not abolish the hypoxic pulmonary vasoconstriction. This is particularly advantageous in patients with pulmonary hypertension, who are prone to develop hypoxia. In the present study the shunt fraction is relatively high (16-33\%). This is in accordance with the findings in previous studies (Clarke and Jackson 1971). An increase in shunt fraction necessitates an increase in inspired oxygen concentration during mechanical ventilation, to maintain acceptable arterial oxygenation. In addition oxygenation is also jeopardized by the reported impairment of the hypoxic pulmonary vasoconstriction (Heidenstierna et al.1986, Heneghan ef al.1984). To optimize oxygenation PEEP was applied which might lead to an increase in PVR (Tyler 1983) and a decrease in cardiac output (Dorinsky and Whitcomb 1983, Jardin et al.1981).

in the immediate post-bypass period pumonary artery pressure tends to be lower due to decreased viscosity of the blood, as a result of hemodilution, and possibly as a result of the implantation of a competent valve (Zener et al.1972). In the course of the early postoperative period pulmonary arterial pressure increases as a consequence of an increase in blood viscosity and sympathetic tone (Mcllduff et al.1980, Heinonen et al.1985, Austen et al.1966, Salmenpera and Heinonen 1986). Because lowering of pulmonary arterial pressure might diminish complications, caused by a further increase in lung water content (Bernard and Brigham 1986) and right ventricular stroke work (Cohn and Franciosa 1977. Sibbald et al.1986), vasodilating agents which reduce pulmonary vascular resistance are primarily administered (Fyman et al.1986). Dobutamine, which was used in the study groups in equal amounts, is a vasodilating agent (Shoemaker et al.1986) able to reduce pulmonary vascular resistance (Molloy et al.1986). However, in the present study dobutamine was mainly used, alone or in combination with dopamine, to increase myocardial contractility (Lappas et al.1977, Sonneblick et al.1979, Lumley et al.1977, Loeb et al.1975, Kirk et al.1978, Salomon et al.1982).

A role for serotonin in pulmonary hypertension has been suggested, since the scavenging function of the lungs with respect to serotonin is impaired in these patients (Vanhoutte et al.1983). Noradrenaline levels are 
also elevated, because the clearing capacity of the lungs for noradrenaline during pulmonary hypertension is insufficient. Since serotonin has an amplifying effect on the vasoconstrictive response to noradrenaline (Van Nueten et al.1982, Forster et al.1980), a contribution of these substances to the pathogenesis of pulmonary hypertension has been postulated (Breuer et al.1985).

The transformation from pacemaker dependent heart rate to spontaneous rhythm during the infusion of sodium nitroprusside might be explained by the reflex tachycardia generally observed following the administration of this compound. This was not observed in the patients receiving ketanserin, since ketanserin does not induce reflex tachycardia (Van der Starre et al.1983).

In conclusion both ketanserin and sodium nitroprusside are effective in the reduction of pulmonary hypertension following valvular surgery, but ketanserin has the advantage of lowering rather than increasing the pulmonary shunt fraction.

\section{Summary}

In a prospective randomized trial in patients with a history of preoperative pulmonary hypertension, undergoing surgery for valvular replacement or annuloplasty, the effects of ketanserin $(n=12)$ and sodium nitroprusside $(n=14)$ on the systemic and pulmonary circulation and pulmonary shunt fraction (Qs/Qt) were studied in the immediate postoperative period. The compounds were administered at the moment that pulmonary arterial pressure tended to rise and cardiac output started to decrease.

Following the administration of the study compounds systemic and pulmonary arterial pressure "systemic and pulmonary vascular resistance, and right ventricular stroke work decreased significantly in both groups. The decrease in mean pulmonary arterial pressure $(p<0.01)$, pulmonary vascular resistance $(p<0.01)$ and right ventricular stroke work $(p<0.05)$ was significantly more pronounced in the ketanserin than in the sodium nitroprusside group. Qs/Qt significantly increased $(p<0.001)$ in the nitroprusside group, but significantly decreased $(p<0.05)$ in the ketanserin group; a significantly different response between the two groups $(p<0.001)$. In 6 patients sodium mitroprusside converted pacemakerdependent heart rate into a spontaneous rhythm, whereas this occurred in only one patient in the ketanserin group.

It is concluded that ketanserin, as opposed to sodium nitroprusside, reduces pulmonary vascular resistance without increasing shunt fraction in the lung, which is particularly advantageous in patients following valvular surgery. 


\section{Chapter 9}

The $\alpha$-adrenergic receptor blocking effect of ketanserin and the interaction between $\alpha$-adrenergic and $\mathrm{S}_{2}$-serotonergic receptor blocking in lowering blood pressure in man 


\section{Introduction}

Ketanserin is a selective $S_{2}$-serotonergic receptor antagonist with $\alpha_{1}$-adrenergic receptor blocking properties (Van Nueten et al.1981, Leysen et al.1981). The compound has shown to be effective in the treatment of high blood pressure, in both essential hypertension (Hedner et al.1985, De Cree et al.1981, Wenting et al.1982) and hypertension following coronary artery bypass surgery (Van der Starre et al.1983, 1986). The mode of action of ketanserin in the treatment of hypertension, however, is incompletely understood. Recent studies in spontaneously hypertensive rats revealed that the antihypertensive effect of ketanserin cannot be explained on the basis of $\mathrm{S}_{2}$-serotonergic receptor blocking alone (Hosie et al.1987). In various studies it has been suggested that the antihypertensive activity of ketanserin may be partly attributed to the $\alpha_{1}$-adrenergic receptor blocking properties of the compound (Reiman and Frolich 1983, Petterson et al.1984, Wenting et al.1984, Vanhoutte 1985, Zabludowski et al.1985, Gasic et al.1985) or to centrally mediated inhibition of sympathetic vascular tone (Phillips et al.1985, McCall and Schuette 1984, Copeland and Bentley 1985). Among the mechanisms postulated the simultaneous blockade of both $\alpha_{1}$-adrenergic and $S_{2}$-serotonergic receptors (Van Nueten et al.1986) is an interesting concept, especially since serotonin and catecholamines have been shown to amplify each other as far as the effect on vascular tone (Van Nueten et al.1982) and arterial blood pressure (Scroop and Walsh 1968) is concerned.

In the present study we investigated the dose dependency of the $\alpha_{1}$ adrenergic receptor blocking properties of ketanserin, if any, the blocking properties of this compound for non-specific stimulation with angioten$\sin$, and the $\alpha_{1}$-adrenergic receptor blocking properties and the blood pressure lowering activity of phentolamine, ritanserin and the combination of both compounds. Phentolamine is a mixed $\alpha_{1} / \alpha_{2}$-adrenergic receptor antagonist (Champoux and Gauthier 1984, Gould and Reddy 1976) and ritanserin a selective $S_{2}$-serotonergic receptor antagonist practically devoid of $\alpha$-adrenergic receptor antagonistic effects (Janssen 1985). Phenylephrine was used as $\alpha_{1}$-adrenergic agonist. The study was performed on patients on cardiopulmonary bypass (CPB) undergoing coronary artery bypass grafting (CABG), a model shown to be suitable to investigate the vascular effects of vasoactive agents (Hsu et al.1979, Boldt et al.1985, 1986, Ellmauer and Brandt 1986, Pauca and Roy 1986). 


\section{Methods}

The study was performed on 121 patients on stable CPB (nasopharyngeal temperature $30-32^{\circ} \mathrm{C}$, flow rate $50 \mathrm{ml} / \mathrm{kg}$ bw and without the necessity of adding additional fluids) undergoing CABG. Patients with impaired myocardial function and/or peripheral vascular disease were excluded from the study. All patients gave informed consent and the study was approved by the Ethical Committee of the hospital.

The patients were ad random allotted to 11 different groups. The demographic data of the patients are depicted in table 1. The study design (table 2) in the various groups was as follows: 3 min after an initial dose (time 0 ) of $0.3 \mathrm{mg}$ phenylephrine (a specific $\alpha_{1}$-adrenergic agonist), the study medication was injected, followed by a second and third dose of $0.3 \mathrm{mg}$ phenylephrine at 5 and $10 \mathrm{~min} . \mathrm{In}$ group $2(\mathrm{NaCl}$, see below) orly the second dose of phenylephrine was administered to prevent an unacceptable rise in blood pressure. In group 11 (see below) a fourth dose of phenylephrine was administered. Mean arterial blood pressure (MAP) was recorded and measured at one min intervals by means of a pressure transducer connected to a radial artery catheter.In the control group (group 1) except for phenylephrine no study medication was administered. In group $210 \mathrm{ml} \mathrm{NaCl}$. $.9 \%$ was injected as study medication to assess whether the solvent itself did cause a significant change in MAP and whether the circulation was still sensitive to -stimulation at $5 \mathrm{~min}$. In the groups 3 through 6 the study medication consisted of $2.5,5,10$, and $20 \mathrm{mg}$ of ketanserin, respectively. In group 7 droperidol ( $10 \mathrm{mg}$ ), a compound with $\alpha_{1}$-adrenergic receptor blocking properties, was used as study medication to assess whether the study design was reliable in this respect. In group $82.5 \mu g$ angiotensin, a non-specific vasoconstricting agent, instead of the second dose of phenylephrine was administered following $20 \mathrm{mg}$ ketanserin to assess whether the hypotensive effect of ketanserin was specifically related to $\alpha$-adrenergic receptor blockade or to a nonspecific mechanism. Phentolamine, $2.5 \mathrm{mg}$ (group 9), ritanserin, $10 \mathrm{mg}$ (group 10), and both compounds simultaneously (group 11.) were administered as study medication to verify whether an interaction exists between $\alpha$-adrenergic and $S_{2}$-serotonergic receptor blocking as far as the lowering of arterial blood pressure is concerned. All compounds were administered into the venous reservoir of the oxygenator. The empirically chosen doses of phenylephrine and angiotensin cause an acceptable rise in MAP during CPB without interfering with the routine protocol of pressures and flow. 
Table 92. Study design in all the groups.

\begin{tabular}{|c|c|c|c|c|c|c|}
\hline Group & $\begin{array}{l}\text { agonist } \\
\text { at } 0 \text { min }\end{array}$ & \multicolumn{2}{|c|}{$\begin{array}{c}\text { study } \\
\text { medication }\end{array}$} & $\begin{array}{l}\text { agonist } \\
\text { at } 5 \mathrm{~min}\end{array}$ & $\begin{array}{l}\text { agonist } \\
\text { at } 10 \mathrm{~min}\end{array}$ & $\begin{array}{l}\text { agonist } \\
\text { at } 15 \mathrm{~min}\end{array}$ \\
\hline 1 & Phene & & & & & \\
\hline 2 & Phene & $\mathrm{NaCl}$ & & & & \\
\hline 3 & Phene & Ket & $2.5 \mathrm{mg}$ & Phene & & \\
\hline 4 & Phene & Ket & $5 \mathrm{mg}$ & Phene & Phene & \\
\hline 5 & Phene & Ket & $10 \mathrm{mg}$ & Phene & Phene & \\
\hline 6 & Phene & Ket & $20 \mathrm{mg}$ & Phene & Phene & \\
\hline 7 & Phene & Drop & $10 \mathrm{mg}$ & Phene & Phene & \\
\hline 8 & Phene & Ket & $20 \mathrm{mg}$ & Ang & & \\
\hline 9 & Phene & Phent & $2.5 \mathrm{mg}$ & Phene & Phene & \\
\hline 10 & Phene & Rit & $10 \mathrm{mg}$ & Phene & & \\
\hline 11 & Phene & $\begin{array}{l}\text { Phent } \\
\text { Rit }\end{array}$ & $\begin{array}{r}2.5 \mathrm{mg} \\
10 \mathrm{mg}\end{array}$ & Phene & Phene & Phene \\
\hline
\end{tabular}

Phene Phenylephrine $0.3 \mathrm{mg} ; \mathrm{NaCl}=\mathrm{NaCl} 0.9 \%$; Ket $=$ Ketanserin;

Drop $=$ Droperidial; Ang = Angiotensin $2.5 \mu \mathrm{g} ;$ Phent $=$ Phentolamine;

Rit $=$ Ritanserin

Statistical analysis. The Wilcoxon signed rank test was applied to compare differences in MAP after the first administration of phenylephrine ( $t=$ $3 \mathrm{~min}$ ) and after the administration of the study medication ( $t=4$ min). The same analysis was applied to compare changes in MAP following the second and third administration of phenylephrine with those after the first administration of phenylephrine.

The Mann-Whitney U-test was applied to compare the starting values of MAP, i.e. before the first administration of phenylephrine, between the various groups, the changes in MAP following the first administration of phenylephrine with those in the same period in the control group (group 1 ), the changes in MAP following the administration of the second dose of phenylephrine with those in the same period in group 2, the changes in MAP following the administration of the study medication in the different groups with those in the same period in group 2, and the changes in MAP following the administration of angiotensin (group 8) with those after the second dose of phenylephrine in group 6 . To evaluate the effect of interventions on the response to the phenylephrine administrations in the various groups the changes in MAP after the second and third dose of phenylephrine were divided by the change in MAP following the first administration of this compound (A- and B-ratio, respectively). The A-ratios, as obtained in the various experimental groups, were compared with the 
ratio obtained in the control $(\mathrm{NaCl})$ group. The $\mathrm{A}$ - and $\mathrm{B}$-ratios in the 5,10 and $20 \mathrm{mg}$ ketanserin-groups and in the droperidol-group were also compared with each other, because only in these groups phenylephrine was administered for the third time. Differences, if any, were evaluated for statistical significance with the use of the Mann-Whitney U-test.

Apart from changes in MAP within the groups, in group 9 through 11 , differences in the changes in MAP between the groups at comparable intervals were statistically evaluated by applying the Mann-Whitney U-test, group 9 serving as control.

The Mann-Whitney U-test was also used to evaluate differences in age and weight for statistical significance. Fisher's exact test was applied for the analysis of sex differences between the groups. The data are presented as mean \pm SEM.

\section{Results}

There were no significant differences in age, weight and sex distribution between the patients in the various groups (Tabie 1). Except for the droperidol group (group 7), in the various groups the mean value of MAP before the first administration of phenylephrine was not significantly different from this value in the control group (group 1). Before the administration of phemylephrine the MAP value was significantly lower in the droperidal group $(p<0.05)$.

In all groups the first administration of phenylephrine significantly increased MAP (Fig 1 through 4). This increase was maintained during the

\begin{tabular}{cccccc}
\hline \multicolumn{7}{c}{ Table 9.1. Demographic data of all the groups (mean \pm SEM) } & & \\
\hline \multicolumn{1}{c}{ Group } & Number & Age (Yrs) & Weight (kg) & Male & Female \\
\hline 1 & 12 & $63.5 \pm 1.55$ & $68.4 \pm 2.69$ & 9 & 3 \\
2 & 13 & $62.4 \pm 1.71$ & $74.8 \pm 2.03$ & 11 & 2 \\
3 & 10 & $61.1 \pm 1.95$ & $74.7 \pm 1.50$ & 8 & 2 \\
4 & 12 & $63.4 \pm 2.13$ & $70.8 \pm 1.83$ & 7 & 5 \\
5 & 12 & $59.1 \pm 1.13$ & $70.1 \pm 2.49$ & 9 & 3 \\
6 & 13 & $58.7 \pm 2.71$ & $73.0 \pm 2.42$ & 8 & 5 \\
7 & 11 & $60.5 \pm 2.07$ & $74.7 \pm 2.78$ & 8 & 3 \\
8 & 12 & $62.4 \pm 1.95$ & $75.4 \pm 1.90$ & 10 & 2 \\
9 & 8 & $58.0 \pm 3.00$ & $72.3 \pm 3.47$ & 4 & 4 \\
10 & 9 & $63.2 \pm 1.68$ & $74.1 \pm 1.63$ & 7 & 2 \\
11 & 9 & $61.6 \pm 2.86$ & $74.6 \pm 2.63$ & 6 & 3 \\
\hline
\end{tabular}




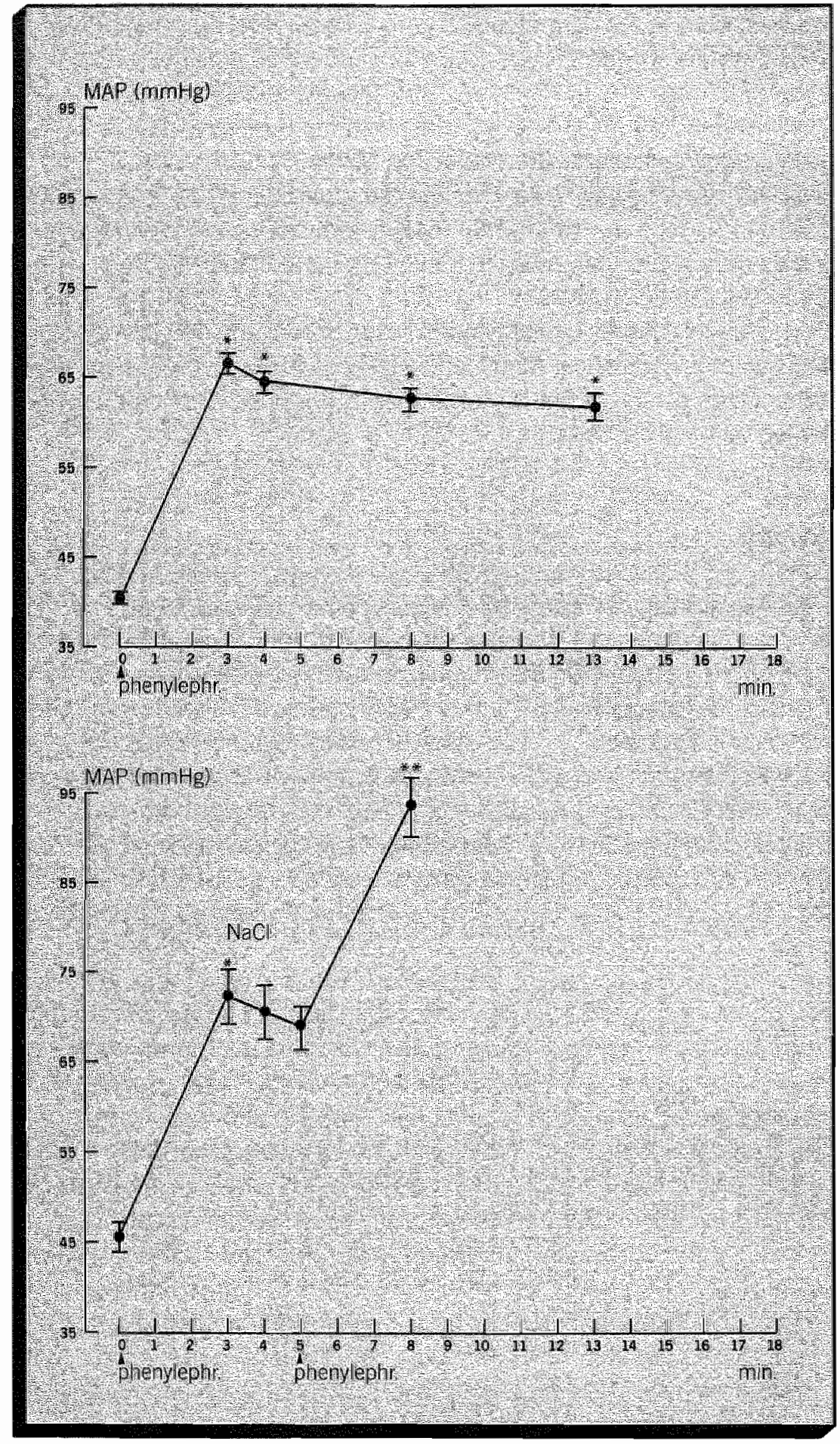


observation period of $13 \mathrm{~min}$ (Fig 1). Ketanserin (2.5,5,10 and $20 \mathrm{mg}$ ) caused a significant reduction of MAP ( $p<0.001$; Fig 2 and 3 ) as compared to the $\mathrm{NaCl}$ group (Fig 1), but the decrease in MAP after the administration of $2.5 \mathrm{mg}$ ketanserin was significantly less than after the injection of $5 \mathrm{mg}(\mathrm{p}<0.05)$, and 10 and $20 \mathrm{mg}(\mathrm{p}<0.01)$. Droperidol ( $10 \mathrm{mg}$ ) significantly lowered MAP (Fig 2), as compared to the NaCl group. The reduction of MAP was more pronounced after the injection of droperidol than after the administration of $2.5 \mathrm{mg}$ ketanserin $(p<0.01)$.

After the injection of $20 \mathrm{mg}$ ketanserin, $2.5 \mu \mathrm{g}$ angiotensin caused a significantly higher increase in MAP $(p<0.001)$ than $0.3 \mathrm{mg}$ phenylephrine (Fig 3). As compared to the $\mathrm{NaCl}$ group the A-ratio"s were significantly smaller in the droperidol and all ketanserin groups than in the $\mathrm{NaCl}$ group (Table 3). The A-ratios in the 10 and $20 \mathrm{mg}$ ketanserin groups were significantly smaller than those in the $2.5 \mathrm{mg}$ and $5 \mathrm{mg}$ ketanserin groups, and the droperidol group ( $p<0.05$ and $p<0.01$, respectively). The A-ratio in the $5 \mathrm{mg}$ ketanserin group was significantly smaller $(p<0.05)$ than that in the $2.5 \mathrm{mg}$ ketanserin group. These ratios were not significantly different from the ratio in the droperidol group. The B-ratio in the $20 \mathrm{mg}$ ketanserin group was significantly lower $(p<0.001)$ than that in the other groups, whereas the B-ratio in the $10 \mathrm{mg}$ ketanserin group was significantly lower $(p<0.01$ ) than that in the $5 \mathrm{mg}$ ketanserin and droperidol groups. There was no significant difference in B-ratios between the $5 \mathrm{mg}$ ketanserin and droperidol groups.

Phentolamine caused a significant decrease $(p<0.05)$ in MAP. The increases in MAP following the second and third dose of phenylephrine, administered after phentolamine, were significantly smaller $(p<0.01)$ than after the first dose (Fig 4). The administration of ritanserin did not significantly change MAP, while the increases in MAP were not significantly different following the first and the second administration of phenylephrine (Fig 4). The combination of phentolamine and ritanserin caused a significantly greater $(p<0.01)$ decrease in MAP as compared with the reduction of MAP after the injection of phentolamine alone (Fig 4). The increases in MAP following the second and third dose of phenylephrine

\section{Fig 9.1.}

Changes in mean arterial blood pressure (MAP, mean \& SEM) following the injection of $0.3 \mathrm{mg}$ phenylephrine (t) alone (top), and before and after NaCi bottom, control group).

* $=p<0.01$ vs time $=0$ min

$=\mathrm{p}<0.01$. vs time $=5$ min 
Fig. 9.2.a

MAP (ninte)

89
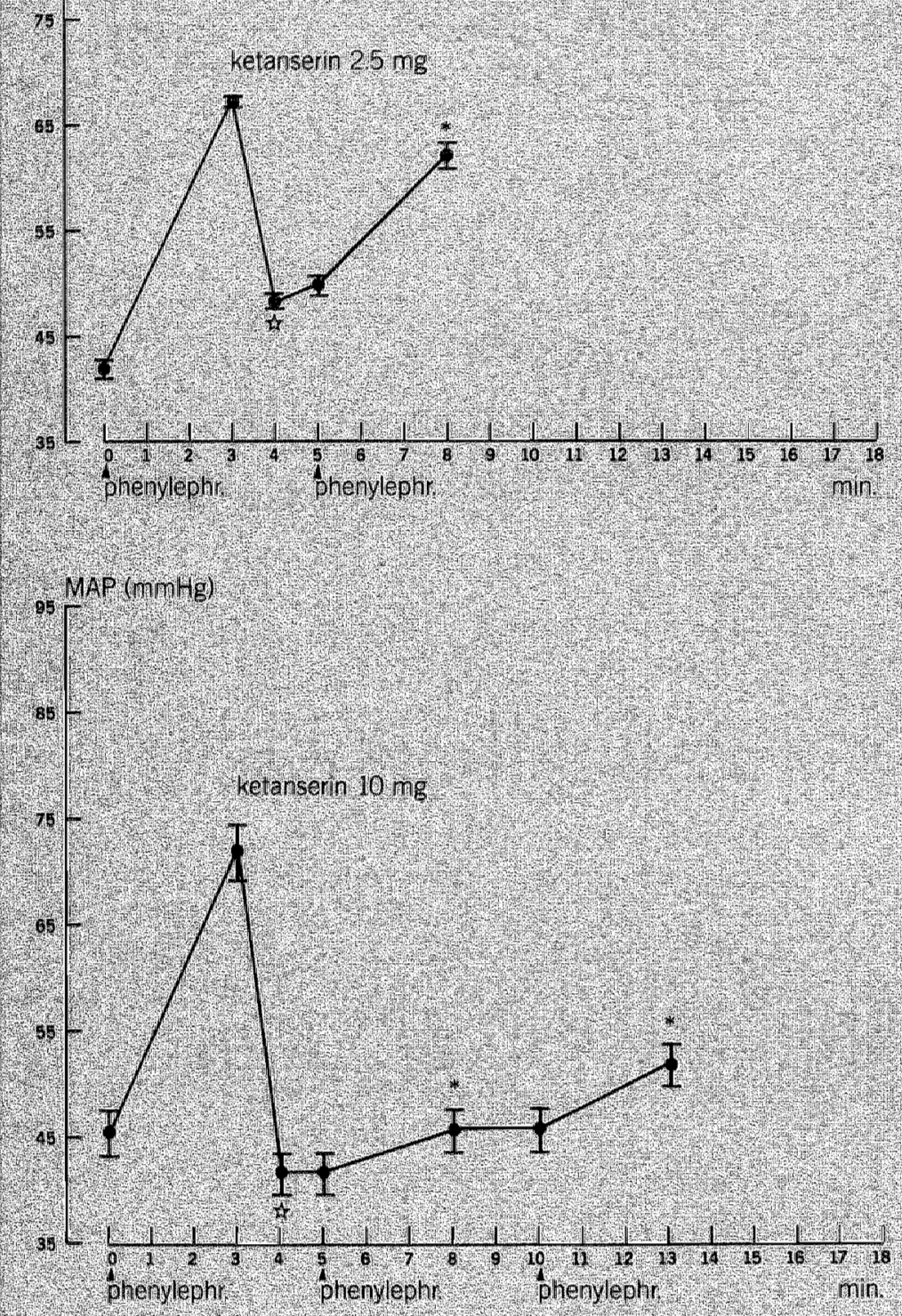

98 

Table 9.3. The degree of $\alpha_{1}$-adrenergic receptor blockade by ketanserin and droperidol, as assessed from A- and B-ratio's.

\begin{tabular}{rlc}
\hline study medication & A-ratio & B-ratio \\
\hline NaCl (control group) & 0.99 & - \\
Ketanserin $2.5 \mathrm{mg}$ & $0.49^{*}$ & - \\
$5 \mathrm{mg}$ & $0.30^{*}$ & $0.36^{*}$ \\
$1.0 \mathrm{mg}$ & $0.16^{*}$ & $0.25^{*}$ \\
$20 \mathrm{mg}$ & $0.10^{*}$ & $0.17^{*}$ \\
$10 \mathrm{mg}$ & $0.25^{*}$ & $0.48^{*}$ \\
\hline
\end{tabular}

* significant difference $(p<0.01)$ with respect to control group $(\mathrm{NaCl})$

A ratio the increase in mean arterial pressure (MAP) after the second dose of phenylephrine divided by the increase in MAP following the first dose of phenylephrine.

B-ratio = the increase in MAP after the third dose of phenylephrine divided by the increase in MAP following the first dose of phenylephrine.

were significantly smaller $(p<0.01)$ after the administration of the combination than after the injection of phentolarnine alone (Fig 4). After the injection of the combination of both compounds the increase in MAP following a fourth dose of phenylephrine was still significantly less than after the first administration (Fig 4).

\section{Discussion}

The findings in this study show that ketanserin reduces the $\alpha_{1}$-agonistic effect of phenylephrine on blood pressure in a dose-dependent way up to a dose of $10 \mathrm{mg}$; a dose of $20 \mathrm{mg}$ ketanserin does not further decrease blood pressure (fig 5). Even a moderate dose of $2.5 \mathrm{mg}$ ketanserin causes a relatively substantial decrease in blood pressure. The degree and dura-

Figi 9.2.a. and Fig 9.2.b.

Changes in mean arterial blood pressure (MAP, mean \pm SEM) in the ketanserin 2.5 , 5 and $10 \mathrm{mg}$ groups and the droperidol $10 \mathrm{mg}$ group.

(1) $=0.3 \mathrm{mg}$ phenyllephrine

is $=0<0,001$ vs $\mathrm{NaCl}$ (control) group

$*=p<0.05$ (changes in MAP after the injection of phenylephrine at $t=5$ min and $t=10$ min ws change in MAP after phenylephrine at $t=0$ min). 
tion of the $\alpha_{1}$-receptor blocking effect appeared to be dose-dependent as well, since the decreases in A- and B-ratio's were significantly more pronounced at increasing doses of ketanserin (table 3 ). The results obtained with the $\alpha_{1}$-adrenergic receptor blocking compound droperidol indicate that the model of cardiopulmonary bypass and moderate hypothermia is suitable to study this type of properties of drugs. The blood pressure lowering and $\alpha_{1}$-adrenergic receptor blocking effect of $5 \mathrm{mg}$ ketanserin appeared to be comparable with those of $10 \mathrm{mg}$ droperidol. The observation that ketanserin did not affect the increase in mean arterial blood pressure as induced by angiotensin, a non-specific vasoconstricting agent, indi-

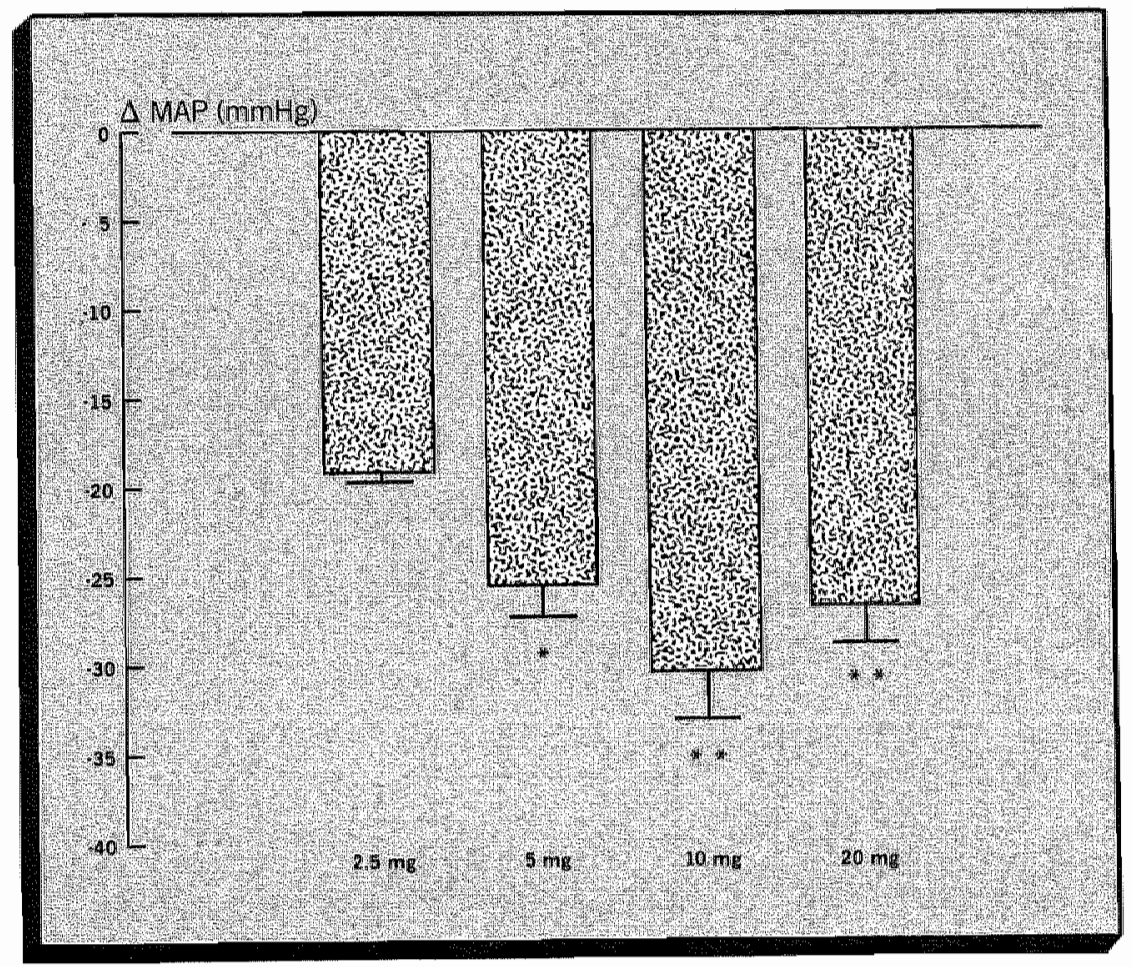

Fig 9.5.

Decrease in mean arterial blood pressure ( $\triangle$ MAP, mean \pm SEM) following $2.5,5$, 10 and $20 \mathrm{mg}$ ketanserin. Note the dose-dependent decrease up to a dose of 10 mg, when a maximum effect is reached.

* $=p<0.05$ vs MAP in the $2.5 \mathrm{mg}$ group

* $=p<0.01$ vs MAP in the $2.5 \mathrm{mg}$ group 
Fig. 9.3.

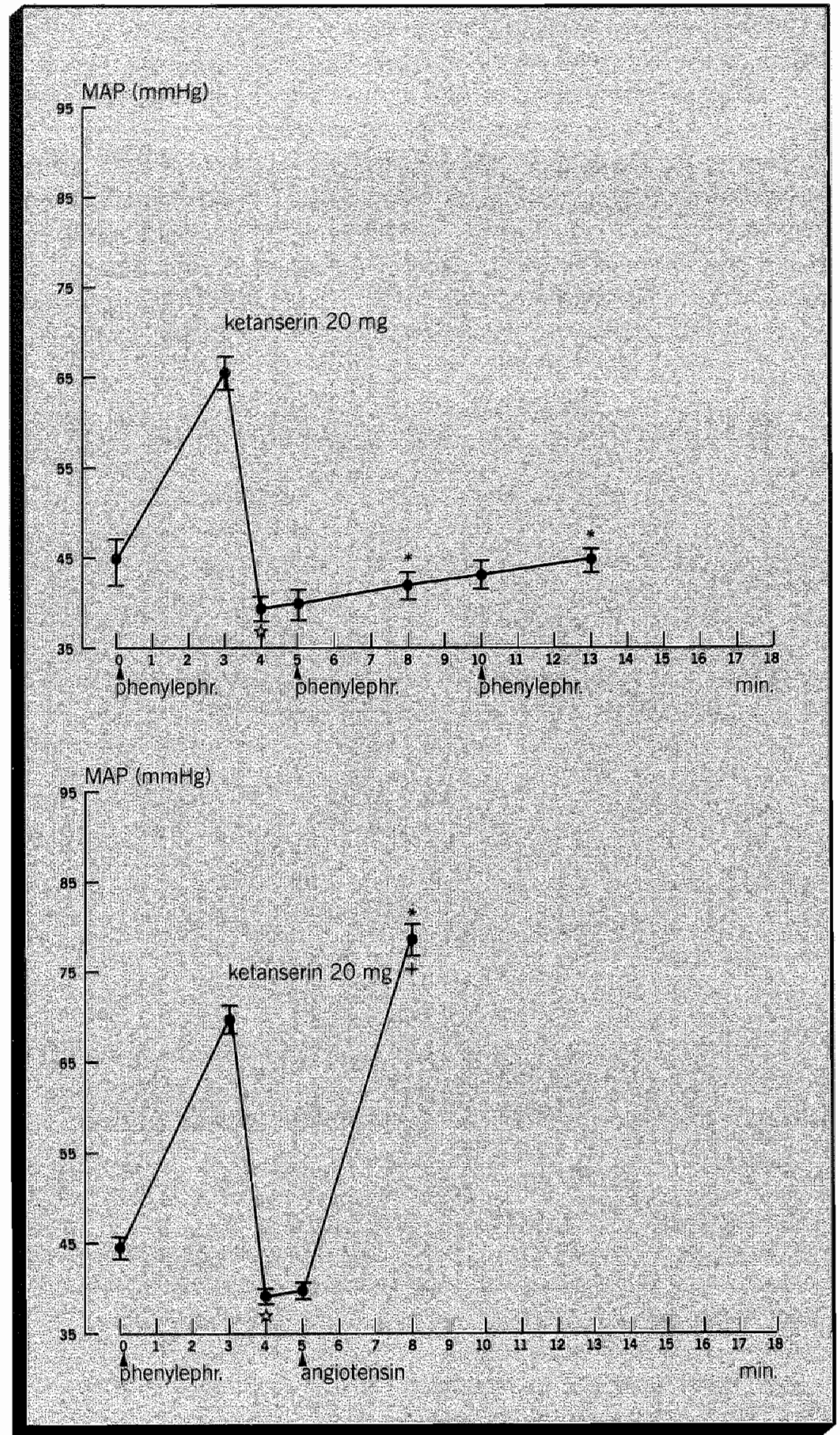


cates that the $\alpha$-blocking properties of Ketanserin are specific.

The findings in the present study also show that the blood pressure lowering effect of ketanserin cannot be explained by $S_{2}$-serotonergic receptor blockade alone, since ritanserin, a specific $S_{2}$-serotonergic antagonist which is rather devoid of $\alpha_{1}$-blocking properties, did not change mean arterial blood pressure. The moderate blood pressure lowering effect of phentolamine is substantially potentiated by ritanserin, demonstrating that combined $\mathrm{S}_{2}$-serotonergic and $\alpha$-adrenergic receptor blocking is required to obtain a substantial reduction in blood pressure. Since ketanserin combines these two properties, it is likely that the blood pressure lowering effect of this compound results from blocking both $\mathrm{S}_{2}$-serotonergic and $\alpha_{1}$-adrenergic receptors.

A critique on the present study may be that we used phentolamine, a mixed $\alpha_{1} / \alpha_{2}$-adrenergic receptor antagonist (Champoux and Gauthier 1984, Gould and Reddy 1976), rather than prazosin, a specific $\alpha_{1}$-adrenergic receptor antagonist, but in The Netherlands this compound is not available in the intravenous form for clinical use.

The model of cardiopulmonary bypass was used in this study because it is considered to be suitable to investigate the peripheral effects of vasodilating agents since feed back mechanisms through the heart are abolished (Hsu et al.1979, Boldt et al.1985,1986, Ellmauer and Brandt 1986, Pauca and Roy 1986). At a constant flow rate the changes in MAP reflect the effect of the compounds on peripheral vascular resistance. The relatively long-lasting increase in arterial blood pressure following the injection of phemylephrine under these experimental circumstances (Fig 1) is a well-known, but incompletely understood phenomenon. It may be possible that the phenylephrine administered interacts with circulating catecholamines, the level of which is increased during cardiopulmonary bypass, or that the metabolism of the compound is delayed because of the

Fig 9.3.

Changes in mean arterial blood pressure (MAP, mean \pm SEM) in the Ketanserin 20 mg-groups.

(M) $=0.3 \mathrm{mg}$ phenylephrine (top)

angiotensin $(t)=2.5 \mu \mathrm{g}$ angiotensin (bottom)

$=p<0.001$ vs $\mathrm{NaCl}$ (control) group

$*=p<0.001$ (changes in MAP after the injection of phenylephrine at $t=5 \mathrm{~min}$ and

$t=10$ min vs change in MAP after phenylephrine at $t=0$ min)

$+=p<0.001$ (difference between the groups with respect to the change in MAP

after the irnjection of phenylephrine (top) or angiotensin (bottom) at $\mathrm{t}=5 \mathrm{~min}$. 


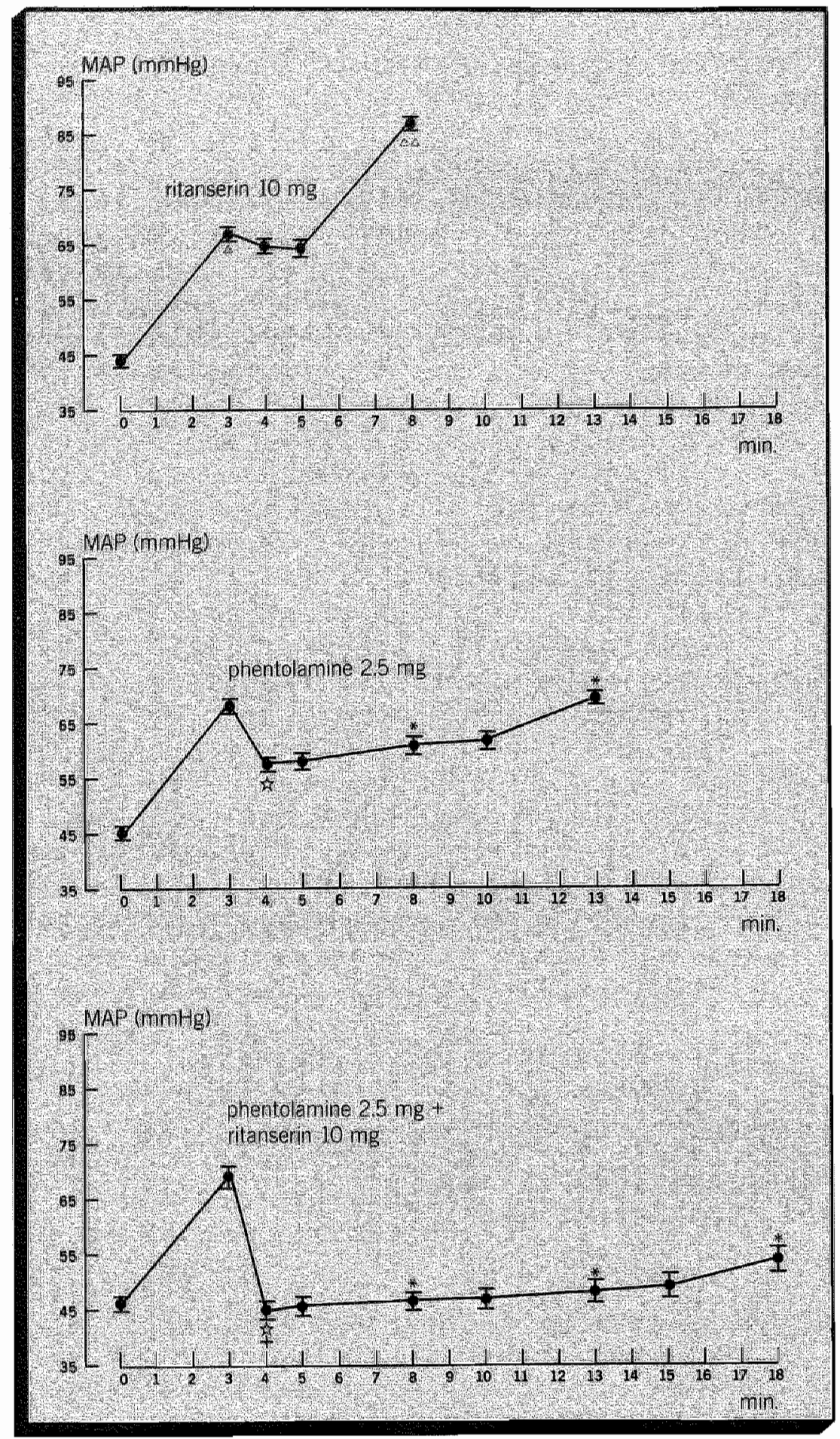


moderate hypothermia.

In conclusion the results of the present study indicate that ketanserin has $\alpha$-blocking properties, but that the blood pressure lowering activity of ketanserin likely results from a combined blockade of $\alpha_{1}$-adrenergic and $\mathrm{S}_{2}$-serotonergic receptors.

\section{Summary}

The $\alpha_{1}$-adrenergic receptor blocking effect of ketanserin, the blocking properties of this compound for non-specific stimulation with angiotensin, and the $\alpha$-adrenergic receptor blocking properties and the blood pressure lowering effect of phentolamine, ritanserin and the combination of both compounds were studied in patients on cardiopulmonary bypass (constant flow rate, mild hypothermia) undergoing coronary artery bypass grafting. Phenylephrine was used as $\alpha_{1}$-adrenergic agonist. Ketanserin is a selective $S_{2}$-serotonergic receptor antagonist with $\alpha_{1}$-adrenergic receptor blocking properties and ritanserin a selective $S_{2}$-serotonergic receptor antagonist practically devoid of $\alpha$-adrenergic receptor antagonistic effects. Phentolamine is a mixed $\alpha_{1}-/ \alpha_{2}$ adrenergic receptor antagonist.

Ketanserin reduces the $\alpha_{1}$-agonistic effect of phenylephrine on blood pressure in a dose dependent way up to a dose of $10 \mathrm{mg}$. Ketanserin did not block the non-specific vasoconstriction, as induced by angiotensin. The moderate blood pressure lowering effect of phentolamine was substantially potentiated by ritanserin, which in itself did not affect blood pressure.

The findings in this study indicate that the blood pressure lowering activity of ketanserin results from a combined blockade of $\alpha_{1}$-adrenergic and $\mathrm{S}_{2}$-serotonergic receptors.

Fig 9.4

Changes in mean arterial blood pressure (MAP, mean \# SEM) in the Ritanserin 10 $\mathrm{mg}$, Phentolamine $2.5 \mathrm{mg}$ and Ritanserin $10 \mathrm{mg} \pm$ Phentolamine $2.5 \mathrm{mg}$ groups.

$\Delta=p<0.01$ vs time $=0$ min

$\Delta \Delta=p<0.01$ vs time $=5 \mathrm{~min}$

$=p<0.001$ ws NaCl (control) group $t=p<0.01$ (difference in change in MAP after the injection of phentolamine (middle) ws phentolamine 4 ritanserin (bottom) at $t=3 \mathrm{~min}$ )

* $=p<0.001$ (difference in changes in MAP after the injection of phenylephrine at $t=5, t=10$ and $t=15$ min vs change in MAP after phenylephrine at $t=0$ min). 


\section{Chapter 10}

\section{Peripheral vascular effects of ketanserin and nifedipine during cardiopulmonary bypass}




\section{Introduction}

Ketanserin, a specific $S_{2}$-serotonergic receptor antagonist (Van Nueten et al.1981, Leysen et al.1981) with $\alpha_{1}$-adrenergic receptor blocking properties (Reimann and Frohlich 1983, Zabludowski et al.1985)), was reported to be an effective antihypertensive agent in patients with essential hypertension (Wenting et al.1984, De Cree et al.1981, McGourty et al.1984, Wing et al.1984), preeclamptic hypertension (Weiner et al.1984) and perand postoperative hypertension (Van der Starre et al.1983, Griffiths and Whitwam 1986, Cashman et al.1986, Nalda et al.1985) following coronary artery bypass grafting (CABG). Haemodynamic investigations showed that ketanserin lowers arterial blood pressure by decreasing systemic vascular resistance without causing reflex tachycardia, as opposed to, for example, sodium nitroprusside (Griffiths and Whitwam 1986, Van der Starre et al.1984). Recently the mechanism responsible for the vasodilating properties of ketanserin has been ascribed to amplification of the $\mathrm{S}_{2}$-serotonergic and $\alpha_{1}$-adrenergic receptor blocking properties of the compound (Van der Starre et al.1987, Van Nueten et al.1986).

Nifedipine, a calcium channel blocking compound, has been extensively studied as cardioprotective (Clark et al.1979, Henry et al.1980) and anti-anginal agent (Emanuelson and Holmberg 1983, Moses et al.1981). More recently the compound was shown to have antihypertensive properties as well (Franklin et al.1986, Van Wezel et al.1986). It was the aim of the present prospective double blind study to investigate the peripheral vascular effects of ketanserin and nifedipine in patients on cardiopulmonary bypass (CPB). CPB was chosen as study model since it offers the possibility to measure independently changes in arterial and venous vascular resistance without the interference of reflex mechanisms of the heart (Hsu et al.1979, Boldt et al.1985,1986, Pauca and Roy 1986).

\section{Materials and methods}

In a double blind prospective study including two groups of 10 patients undergoing coronary artery bypass grafting (CABG) $10 \mathrm{mg}$ ketanserin or $2 \mathrm{mg}$ nifedipine were injected into the venous reservoir of the oxygenator during stable CPB when mean arterial blood pressure (MAP) was higher than $50 \mathrm{mmHg}$. All patients had a normal myocardial function and no peripheral vascular disease. They gave informed consent and the protocol was approved by the Ethical Committee of the hospital. The intravenous anesthetic technique consisted of fentanyl $75 \mu \mathrm{g} / \mathrm{kg}$, pancuronium bromide $0.1 \mathrm{mg} / \mathrm{kg}$ and midazolam $0.15 \mathrm{mg} / \mathrm{kg}$. The patients were ventilated 
with $100 \% \mathrm{O}_{2}$ and no inhalational agents were used. If hypertension (systolic blood pressure higher than $130 \mathrm{~mm} \mathrm{Hg}$ ) developed in the pre-bypass period, a nitroglycerin infusion was started. No anesthetics were administered during the study periad in which the flow rate was kept constant at $50 \mathrm{ml} / \mathrm{kg} \mathrm{bw} / \mathrm{min}$ and the temperature (nasopharyngeal) at approximately $30^{\circ} \mathrm{C}$. No fluids were added unless the fluid level in the reservoir of the oxygenator (Harvey) tended to become unacceptably low.

After the administration of the study medication MAP and the fluid level in the venous reservoir of the oxygenator were recorded after $30 \mathrm{sec}, 1$, 5 and $10 \mathrm{~min}$. The Wilcoxon signed rank test was applied to evaluate intragroup differences and the Mann-Whitney U-test to evaluate intergroup differences for statistical significance. A probability value of $p<0.05$ was considered to indicate a significant difference.

\section{Results}

The groups were comparable as far as age, weight and sex distribution are concerned (table 1). There was also no significant difference in the MAP

Table 10.1 Demographic data of the patients in both groups (mean \pm SEM)

\begin{tabular}{lcc} 
& $\begin{array}{c}\text { Ketanserin } \\
\text { group }\end{array}$ & Nifedipine \\
& 10 & group \\
\hline number $(\mathrm{n})$ & $56 \pm 11.3$ & 10 \\
age (years) & $75 \pm 8.7$ & $60 \pm 7.6$ \\
weight ( $\mathrm{kg}$ ) & $9 / 1$ & $74 \pm 6.9$ \\
sex (male/female) & & $8 / 2$ \\
\hline
\end{tabular}

The differences between the lwo groups were not statistically significant

values and the fluid level in the venous reservoir of the oxygenator at the moment of the administration of the study medication (control values). After the injection of ketanserin MAP significantly decreased from $55 \pm$ 2.5 to $38 \pm 2.4 \mathrm{mmHg}$ at $\mathbb{1 m i n}(p<0.01)$ and to $47 \pm 2.3 \mathrm{mmHg}$ at $5 \mathrm{~min}(\mathrm{p}<0.05)$. The control values were reached again $10 \mathrm{~min}$ after injection. (fig 1). The fluid level of the venous reservoir was significantly lower 5 and $10 \mathrm{~min}(p<0.05)$ after the administration of the compound. At $10 \mathrm{~min}$ the level was significantly lower $(p<0.05$ ) than at $5 \mathrm{~min}$ (fig 2). Immediately following the study period in 4 patients additional fluid (Ringer's lactate) had to be infused to prevent the fluid level in the venous 
reservoir from failing to an unacceptably low level. After the injection of nifedipine MAP significantly decreased from $59 \pm 3.2$ to $44 \pm 4.6 \mathrm{mmHg}$ at $1 \mathrm{~min}(p<0.01)$ and to $48 \pm+4.9 \mathrm{mmHg}$ at $5 \mathrm{~min}(p<0.05)$. Ten min after injection the MAP values were not significantly different from the control values anymore (fig 1 ). The fluid level in the venous reservoir was slightly, but significantly increased at $1 \mathrm{~min}(p<0.05)$. Five and $10 \mathrm{~min}$ after administration of the compound the levels were not significantly different from those in the control situation (fig 2). There were no significant differences between the changes in MAP in both groups, but at 10 min the

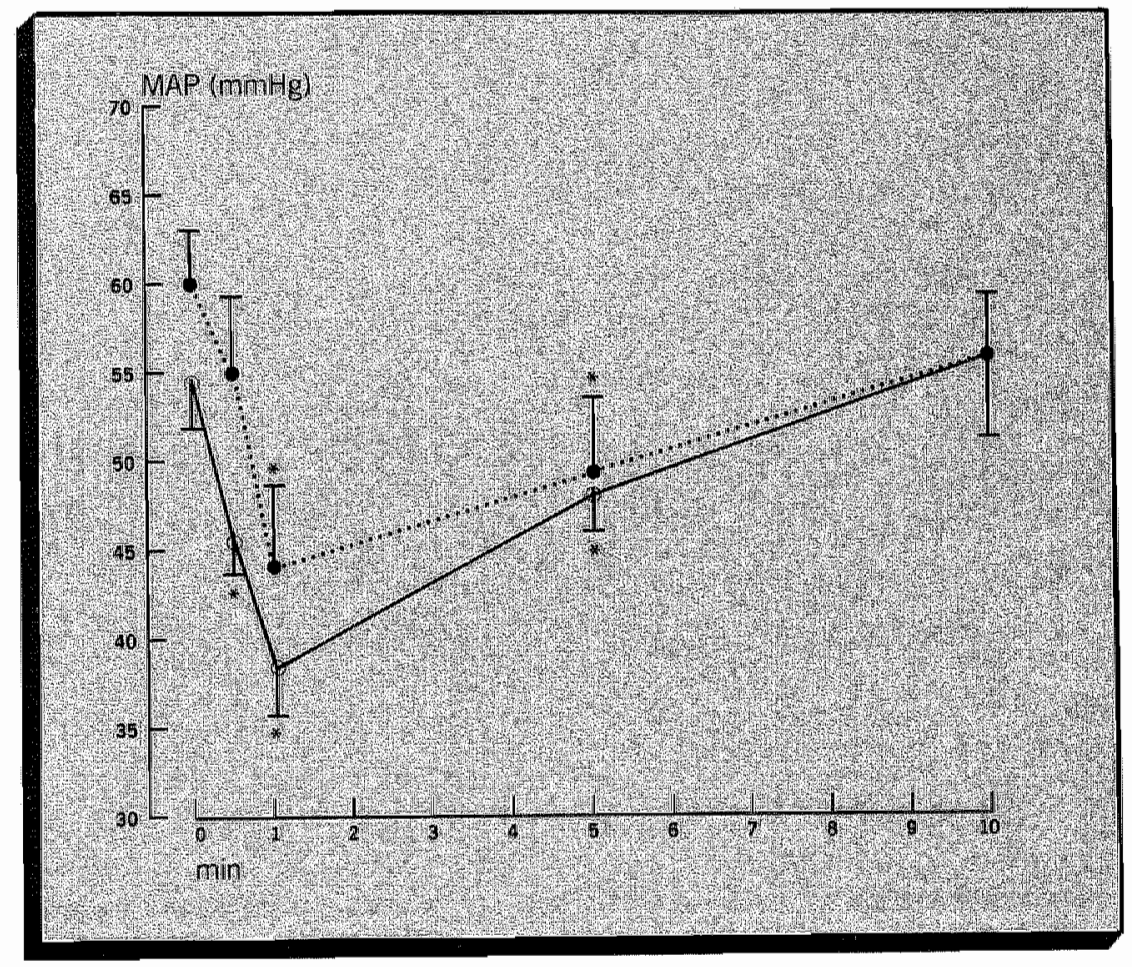

Fig.10.1

Changes in mean arterial blood pressure (MAP, mean \pm SEM) during cardiopulmonary bypass following the administration of $10 \mathrm{mg}$ ketanserin or $2 \mathrm{mg}$ nifedipine.

..... = nifedipine

- $=$ ketainserin

$*=p<0.05$ (intragroup) 
fluid level in the venous reservoir was significantly lower $(p<0.05)$ in the ketanserin than in the nifedipine group.

\section{Discussion}

The findings in this study indicate that both ketanserin and nifedipine are potent arterial vasodilating agents, but that ketanserin, unlike nifedipine,

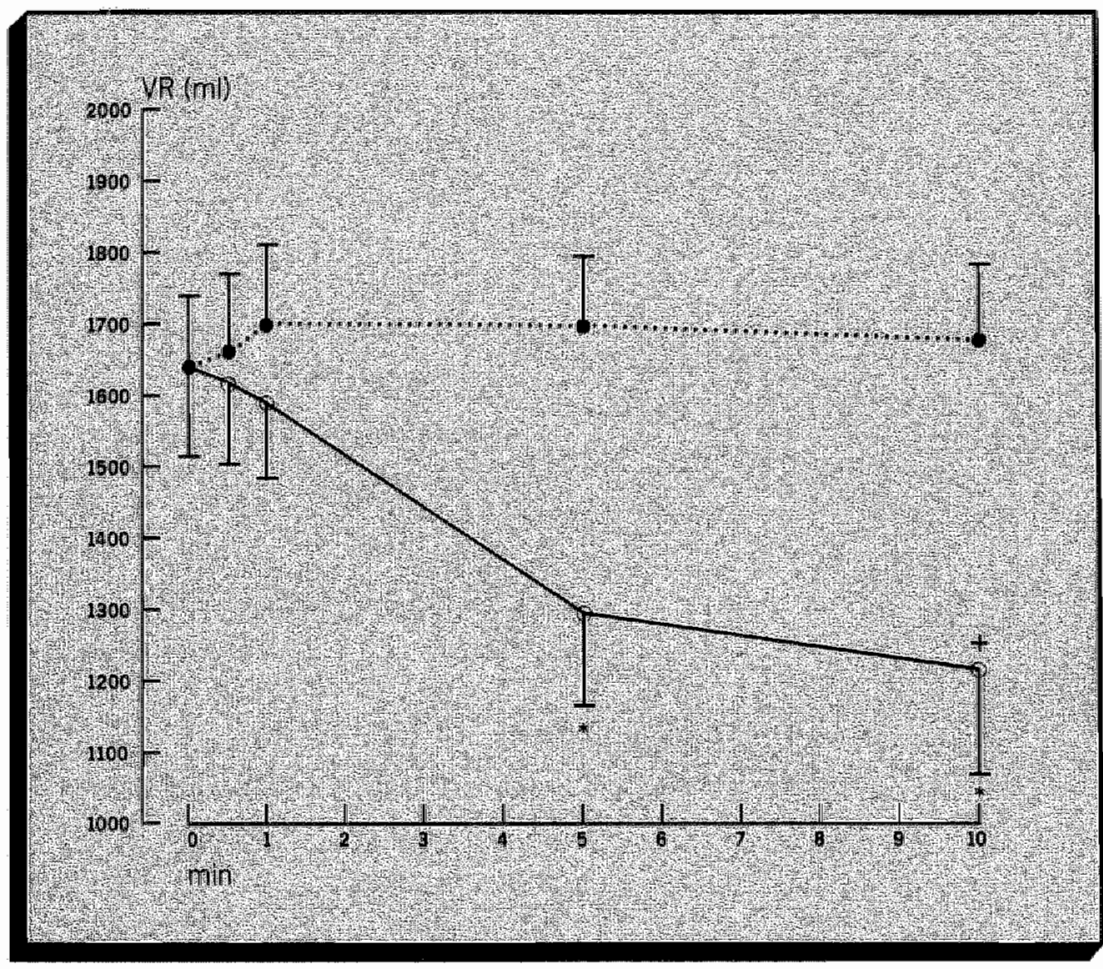

Fig.10.2

Changes in the fluid level of the venous reservoir of the oxygenator (VR, mean \pm SEM) during cardiopulmonary bypass following the administration of $10 \mathrm{mg}$ ketanserin or $2 \mathrm{mg}$ nifedipine.

..... nifedipine

-0 - ketanserin

$*=p<0.05$ (intragroup)

$+=p<0.05$ (intergroup) 
also dilates venous capacitance vessels. Venous vasodilatation might be important in antihypertensive treatment during and following cardiac surgery since venous tone gradually increases in the course of cardiopulmonary bypass (Gall et al.1982) due to increased catecholamine levels, mainly caused by hypothermia (Chernow et al.1983), hemodilution (Hine et al.1976) and non-pulsatile flow (Landymore et al.1979). The blood pressure lowering effect of ketanserin probably results from an interaction between the $S_{2}$-serotonergic and $\alpha_{1}$-adrenergic receptor blocking properties of the compound, because $S_{2}$-serotonergic receptor blockade alone did not change arterial biood pressure, but significantly potentiated the decrease in arterial blood pressure, as induced by $\alpha_{1}$-adrenergic receptor blockade (Van der Starre et al.1987).

Recently the antihypertensive activity of nifedipine has been studied (Hess and Meyer 1986, Majid and De Jong 1982) in patients with ischemic heart disease. Reflex tachycardia was reported as the main side effect. Such a reflex mechanism could also be responsible for the shortlasting venous vasoconstriction observed in this study. Apparently the arterial and venous side of the vasculature react differently when exposed to calcium channel blockers, which has been suggested before (Van Nueten and Wellens 1979, Mostbeck et al.1976). Calcium also plays a role in serotonergic-receptor stimulation (Erne and Pletscher 1985. Maggi et al.1983), but mainly as second messenger. The reflex tachycardia during antihypertensive treatment with nifedipine might be harmful to ischemic myocardium since it likely increases oxygen demand of the already deprived myocardium. Although ketanserin dilates both arterial and venous vessels, like nitroprusside and nitroglycerin (Gerson et al.1982), heart rate does not change during antihypertensive treatment with this compound (Van der Starre et al.1986). Ketanserin might block the baroreceptor reflex to arterial and venous vasodilatation as a consequence of a central mode of action (Phillips et al.1985, Copeland and Bentley 1985, McCall and Schuette 1984, Lakoski and Aghajanian 1985).

In conclusion ketanserin and nifedipine were found to be effective in lowering arterial blood pressure. Ketanserin appeared to have a dilating effect on both the arterial and the venous side of the vasculature, while nifedipine only dilates arterial vessels. Therefore, in the antihypertensive treatment during and following cardiac surgery ketanserin might have advantages over nifedipine, since venous tone is generally increased under these circumstances. Besides, the previously reported reflex tachycardia, as induced by nifedipine, is an unwanted side effect. 


\section{Summary}

Ketanserin, a selective $S_{2}$-serotonergic receptor antagonist with $\alpha_{1}$-adrenergic receptor blocking properties, as well as nifedipine, a classic calcium channel blocker, is used as antihypertensive agent during and following cardiac surgery. In a double blind prospective study, using hypothermic cardiopulmonary bypass as study model, ketanserin ( $10 \mathrm{mg}$ iv) and nifedipine (2mgiv) were evaluated with respect to their effects on the peripheral circulation. The results showed that ketanserin and mifedipine dilate the arterial side of the vasculature, but that ketanserin, unlike nifedipine, also dilates the venous capacitance vessels; nifedipine even caused a shortlasting venous vasoconstriction. Since venous tone is increased during and following cardiopulmonary bypass, antihypertensive treatment with ketanserin might be advantageous under these circumstances. 
Chapter 11

General discussion 


\section{General discussion}

The findings in the studies presented in this thesis indicate that ketanserin is effective in the treatment of hypertension during and following coronary artery bypass surgery, but does not completely prevent per- and postoperative hypertension when administered as a continuous infusion from the start of anesthesia. The compound is also effective in the treatment of pulmonary hypertension. In contrast to sodium nitroprusside, ketanserin does not induce a reflex tachycardia and does not increase the pulmonary shunt fraction, either in the treatment of postoperative hypertension following coronary artery bypass surgery or in the treatment of pulmonary hypertension following valvular surgery. The compound improves diuresis peroperatively, and was found to be a potent arterial and venous vasodilating agent, in contrast to the calcium entry blocker nifedipine, which only dilates arterial vessels.

The antihypertensive effect of ketanserin in the postoperative period is caused by a decrease in systemic vascular resistance. A continuous infusion of ketanserin to prevent hypertension during surgery caused a lowering of arterial blood pressure, associated with a reduction of cardiac output and heart rate, and an increase in systemic vascular resistance, although this latter effect remained within acceptable limits. The higher systemic vascular resistance during ketanserin infusion than during infusion of its solvent can be explained by the significantly less frequent use of nitroglycerin in the ketanserin group. The decrease in arterial blood pressure in the presence of an increase in systemic vascular resistance probably results from predominant venous vasodilatation, especially since stroke volume decreases under these circumstances.

From the findings in the first clinical studies of this thesis it was concluded that serotonin plays a major role in the genesis of postoperative hypertension. At that time only the $S_{2}$-serotonergic receptor blocking effects of ketanserin were known. Later the assumption was made that the blood pressure lowering effect of ketanserin is specifically due to alpha-adrenergic receptor blockade (Reimann and Frohlich 1983a, Gasic et al.1985). However this is unlikely since ketanserin also lowers arterial blood pressure in patients with complete autonomic insufficiency (Wenting et al. 1984). Since ritanserin, a specific $S_{2}$-serotonergic antagonist devoid of alpha $a_{1}$-adrenergic receptor blocking properties, does not affect arterial blood pressure, a pure $\mathrm{S}_{2}$-serotonergic receptor blockade as explanation for the blood pressure lowwering effect is also unlikely. According to the findings in the study presented in chapter 9 , ketanserin clearly demonstrates alpha $\mathrm{l}_{1}$-adrenergic receptor blocking properties, since the alpha $\mathrm{p}_{1}$ agonistic effect of phenylephrine was dose-dependently antagonized. 
The maximal blood pressure lowering effect was obtained with a dose of $10 \mathrm{mg}$ ketanserin IV. Increasing the dose up to $20 \mathrm{mg}$ resulted only in an increase of the duration of the alpha, ${ }_{1}$-adrenergic receptor blocking effect. in the same study $S_{2}$-serotonergic receptor blockade appeared to amplify the alpha-adrenergic receptor blocking effect of phentolamine. This finding is in agreement with a previous study in animals (Van Nueten et al.1986), in which an interaction between $S_{2}$-serotonergic and alpha-adrenergic receptor blockade was also reported. It is concluded that per-and postoperative hypertension can be effectively treated by simultaneously blocking alpha $a_{1}$-adrenergic and $S_{2}$-serotonergic receptors. Ketanserin combines both properties.

Heart rate does not change during the administration of ketanserin. This might be due to an interaction with the baroreceptor reflex (Smits et al.1987), but in a recent study in rabbits (Takata et al.1986) an alteration of baroreceptor function was found not to be involved in the antilhyperten" sive effects of ketanserin. Several authors have suggested the possibility that ketanserin has a central mode of action (Petterson et al.1984, Lakoski et al.1985, Mylechrane et al.1985), leading to an increased vagal and a decreased sympathetic activity (McCall and Schuette 1984). This could be an explanation for the absence of reflex tachycardia. In this context Fozard (1982) reported a reduction of heart rate in rats treated with ketanserin, which could be inhibited by vagotomy. An alternative explanation for the absence of reflex tachycardia could be that ketanserin directly slows the pacemaker-function of the sinus node (Saman et al.1985), but this could not be confirmed in a study in closed-chest dogs (Van de Water et al.1978). In a study on dogs (Furukawa et al.1986) the negative chronotropic effect of ketanserin was potentiated by propranolol. Since all the patients undergoing coronary artery bypass surgery studied were preoperatively treated with beta-adrenergic receptor blockers, an interaction between ketanserin and the residual level of beta-adrenergic receptor blockade might be postulated. Van de Water et al. (1985) observed an increase in heart rate after the acute administration of ketanserin in an intact dog model. This discrepancy with the reported clinical studies is incompletely understood, but might result from differences in baroreceptor sensitivity.

The finding that ketanserin is a potent dilator of the venous capacitance vessels is particulary important for patients undergoing cardiac surgery since cardiopulmonary bypass causes a substantial increase in venous tone (Gall et al.1982). In a study on human saphenous veins (Docherty and Hyland 1986) this effect was ascribed to specific $S_{2}$-serotonergic receptor blockade, since alpha $a_{1}$-and alpha $a_{2}$-adrenergic receptor blocking compounds did not affect the serotonin induced contractions. In portal hypertensive rats ketanserin substantially reduced portal pressure 
(Cummings et al.1986) due to venous dilatation and pooling of blood in the portal venous system. This effect was assumed to be secondary to blockade of $S_{2}$-serotonergic receptors.

In the study on the venous dilatory properties of ketanserin (chapter 10) and in the study on the underlying mechanism of the blood pressure lowering effect of the ketanserin (chapter 9), cardiopulmonary bypass was used as study model, since it gives the opportunity to evaluate the peripheral effects of a compound without interference from reflex mechanisms of the heart. It was interesting to observe that peripheral (skin) temperature increased during the continuous infusion of ketanserin, despite a simultaneous increase in systemic vascular resistance. This effect might be related to specific $S_{2}$-serotonergic receptor blockade in the skin.

The continuous infusion of ketanserin during surgery induces a significant increase in diuresis before and during cardiopulmonary bypass. The underlying mechanism of this effect is unclear. Previous reports mentioned that serotonin has an antidiuretic effect and causes vasoconstriction of the renal vessels (Garattini and Valzelli 1965). The presence of vasoconstricting agent identified as serotonin was related to the often observed oliguria during and following cardiopulmonary bypass (Frick 1960, Sarajas et al.1959). Recently glomerular filtration rate and renal blood flow were reported to remain unchanged during the administration of ketanserin despite a decrease in arterial blood pressure (Woittiez et al.1985, De Leeuw and Birkenhager 1985). In dogs ketanserin reversed the serotonin induced decrease in renal blood flow at a dose level not affecting the response to the administration of phenylephrine, indicating that this effect of ketanserin may be due to specific $\mathrm{S}_{2}$-serotonergic receptor blockade (Blackshear et al.1986). It is postulated that the improved diuresis during ketanserin infusion results from an enhanced renal blood flow, which is an important phenomenon since acute renal failure often complicates major surgery (Abel et al.1980, Hilberman et al.1979).

The finding that ketanserin does not increase pulmonary shunt fraction is particularly important for patients undergoing cardiac surgery, since shunt fraction substantially increases during these procedures due to such mechanisms as an increase in extravascular lung water (Boldt et al.1986, Gallagher 1985), complement activation (Chenoweth et al.1981, Jones et al.1982), mechanical ventilation and general anesthesia (Rehder et al.1975). The routine use of vasodilating agents like sodium nitroprusside, nitroglycerin and hydralazine cause an increase in pulmonary shunt fraction (D'Oliviera et al.1981, Berthelsen et al.1986, Sandoval et al.1986, this thesis) because they abolish the hypoxic pulmonary vasoconstriction. Apparently ketanserin does not cause a change in the distribution of pulmonary blood flow. In patients with pulmonary hypertension the scaven- 
ging function of the lungs with respect to catecholamines and serotonin was reported to be reduced (Gillis et al. 1974), causing increased activity of these vasoactive compounds. Since ketanserin induces both $\mathrm{S}_{2}$-serotonergic and alpha ${ }_{1}$-adrenergic receptor blockade, the treatment of these patients with ketanserin, aiming at a reduction of pulmonary artery pressure may be prefered.

The findings in this thesis indicate that serum levels of serotonin do not change during and following cardiopulmonary bypass. This is in contradiction with the reports of other authors who previously suggested the involvement of serotonin in the development of perioperative hypertension (Sarajas et al.1959, Ilicin et al.1972, Replogle et al.1962, Swank et al.1964). The present findings are in agreement with those of Demos et al. (1970), Anger et al.(1986) and Feddersen (1985) who obtained similar results. This does not necessarily exclude a role for serotonin in the genesis of thypertension during and following coronary artery bypass surgery. The absence of an increase in serum serotonin levels might result from rapid elimination of serotonin from the plasma by endothelial cells and/or platelets. Serotonin amplifies the vasoconstrictive response induced by catecholamines (Van Nueten et al.1982), indicating that relatively small amounts of serotonin, locally released from activated platelets, might be enough to induce constriction of smaller arteries and arterioles, and hence cause hypertension.

In conclusion ketanserin, in patients undergoing coronary artery surgery, appeared to be an effective antihypertensive agent without causing an increase in heart rate and pulmonary shunt fraction. Ketanserin causes a stable hemodynamic condition if administered as a continuous infusion during surgery. Ketanserin induces an increase in diuresis before and during cardiopulmonary bypass. It reduces pulmonary artery pressure in patients with pulmonary hypertension following valvular surgery. The assumption that serotonin plays a role in the etiology of per and postoperative hypertension could not be confirmed. The blood pressure lowering effect of ketanserin may be explained by both alpha $a_{1}$-adrenergic and $\mathrm{S}_{2}$-serotonergic blockade. 
Chapter 12

\section{Summary}




\section{Summary}

An important problem for the anesthesiologist is the prevention and treatment of hypertension during and following cardiac surgery.

In the introduction of this thesis the incidence and causes of this form of hypertenion is reviewed. A distinction is made between the type of hypertension which develops before the start of cardiopulmonary bypass, during cardiopulmonary bypass, in the period immediately following the termination of cardiopulmonary bypass and postoperatively, in the first hours after arrival in the intensive care unit (ICU). The treatment of hypertension is particullarly important in the period before cardiopulmonary bypass because it can cause myocardial damage, increased blood loss and possibly cerebral haemorrhage, especially in the eiderly patient. Hypertension in this period is mainly caused by the stress of laryngoscopy, intubation, sternotomy and sternal spread. During these manupulations pressor effects occur leading to a significant increase in the plasma levels of catecholamines, vasopressin as well as renin and angiotensin. Increased plasma serotonin levels may also play a role.

Hypertension during cardiopulmonary bypass has other causes. The concentrations of catecholamines in the plasma increase, particularly umder the influence of hemodilution, hypothermia, hypotension and the application of non-pulsatile flow. During cardiopulmonary bypass damage of blocd platelets occurs, leading to the release of beta-thromboglobulin, platelet factor-4, thromboxane B2 and possibly serotonin. In the period immediately following cardiopulmonary bypass hypertension rarely occurs because the heart has to recover from the ischemic insult resulting from aortic clamping during CPB. At this stage hypertension may develop only in the presence of severe peripheral vasoconstriction.

In the early postoperative phase in the ICU hypertension often develops ( $40-60 \%$ of the coronary bypass patients). Factors like the maintained elavated plasma levels of catecholamines, the diminishing efficacy of the pre-operative beta-blockade may be responsible for this hypertension. The patients arousal during this period may lead to intolerance of the endotracheal tube which may also cause hypertension. It is unclear whether serotonin plays a role in this process. In this phase hypertension may cause the same complications as in the period before cardiopulmonary bypass. In addition it is assumed that hypertension may lead to early closure of coronary bypass grafts.

Because perioperative hypertension is generally treated by means of vasodilators, a review is presented of the existing intravenous antihypertensive agents of which sodium nitroprusside and nitroglycerin are most commonly used. Recently developed antihypertensive compounds, like 
urapidil, adenosine and ketanserin are discussed. The latter is a $\mathrm{S}_{2}$-sero-


properties, which was found to be effective in the treatment of patients with essertial hypertension.

Thereafter a short review is presented of the origin, metabolism and effects of serotonin. Serotonin is synthetized in the chromaffine cells of the gastro-intestinal tract. After release the compound is almost completely metabolized in the liver. The residual serotonin is taken up by endothelial cells, especially in the lung. Small amounts of serotonin, which pass the lung, are stored in blood platelets, resulting in very small amounts of free serotonin in plasma. Serotonin may cause vasodilatation as well as vasoconstriction, depending of the type of blood vessel and the basic vascular tone. Serotonin is liberated from aggregating platelets causing for example vasoconstriction in arteries, an effect mediated by $S_{2}$-serotonergic receptors. Serotonin dilates arterioles probably via $S_{1}$-serotonergic receptors, an effect in which the "endothelium-derived relaxing factors (EDRF)" may play a role. Serotonin also amplifies vasoconstriction, as induced by vasoconstricting agents, like catecholamines and angiotensin. Especially through this mechanism serotonin is believed to play a role in the origin of hypertension. In pathological conditions like atheroslerosis, pulmonary hypertension, endotoxic shock and ecclampsia, an increased activity of serotonin has been demonstrated. Eventually in the last part of the first chapter the aim of this thesis is presented.

In the second chapter a short review is presented of the pharmacology of ketanserin. Ketanserin is a specific $\mathrm{S}_{2}$-serotonergic receptor blocker with alpha, ${ }_{1}$-adrenergic receptor blocking properties. The compound is devoid of $S_{1}$-serotonergic receptor blocking properties. It is a quinazoline derivative with a half life of 15 hours. Ketanserin is mainly metabolized in the liver to non-active metabolites. The most important application is its use as antihypertensive agent, especially in patients with essential hypertension, preecclampsia, pulmonary hypertension and neurogenic hypertension. It is also administered in patients with peripheral vascular disease like Raynaud's disease, Burger's disease and diabetes mellitus. Before the start of this thesis the antihypertensive effect of ketanserin was ascribed to different mechanisms: sole $\mathrm{S}_{2}$-serotonergic receptor blockade, sole

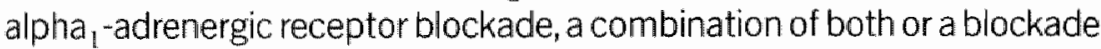
of the sympathetic outflow of catecholamines by an interaction on central alpha, -adrenergic receptors.

The clinical part of the thesis starts with a review of the techniques applied in anesthesia, surgery, cardiopulmonary bypass and general postoperative treatment (chapter 3 ).

The first clinical study (chapter 4) consists of a double blind prospec- 
tive study, in which ketanserin or the solvent of ketanserin is administered per and postoperatively as a continuous infusion in patients undergoing coronary artery bypass surgery. Changes in hemodynamics and the plasma levels of humoral factors are measured. In addition the amounts of fentanyl and nitroglycerin administered are determined, as well as peroperative diuresis. During ketanserin infusion blood pressure, heart rate and cardiac output are reduced, and peripheral vascular resistance is higher than during solvent administration. In both groups the plasma levels of catecholamines, renin and angiotensin increase significantly during and following surgery, but the concentrations of serotonin do not significantly change. In the ketanserin group the peripheral (skin) temperature and diuresis are higher, which might be caused by specific $S_{2}$-serotonergic receptor antagonism in these tissues. During the infusion of ketanserin lower doses of fentanyl and less frequent administrations of nitroglycerin are necessary to treat hypertensive episodes.

In chapter 5 an open study is presented showing that ketanserin is effective in the treatment of postoperative hypertension following coronary surgery. The decrease in blood pressure is caused by a decrease in peripheral vascular resistance but heart rate does not increase, leading to a significant decrease of the triple index (the product of systolic blood pressure, heart rate and left atrial pressure), indicating that the oxygen demand of the heart diminishes.

In chapter 6 the results, as obtained in chapter 5 are evaluated in a prospective double blind study in a similar group of patients. Ketanserin decreases blood pressure in significantly more patients than does its solvent.

In chapter 7 ketanserin is compared with sodium nitroprusside, the intravenous antihypertensive agent routinely used, in a comparable group of patients as described in chapter 5 and 6 . Both substances are effective in decreasing blood pressure. As opposed to ketanserin, sodium nitroprusside causes reflex tachycardia and an increase in pulmonary shunt fraction, probably caused by a decrease in hypoxic pulmonary vasoconstriction.

In chapter 8 ketanserin is compared with sodium nitroprusside in the treatment of pulmonary hypertension in patients undergoing valvular surgery. In these patients pulmonary dysfunction due to cardiac failure, has already existed for a long period of time. Both vasodilators are effective in lowering pulmonary vascular resistance. However, sodium nitroprusside causes an increase in pulmonary shunt fraction also in these patients, as opposed to ketanserin.

To obtain more insight into the underlying mechanism of the blood pressure lowering effect of ketanserin the model of cardiopulmonary bypass was used (chapter 9 ) because it allows the the investigation of the ef- 
fects of compounds on peripheral circulation without interference of cardiac reflexes. The blood pressure lowering effect of ketanserin is dose dependent, with a maximal effect at a dose of $10 \mathrm{mg}$. Ketanserin also appears to possess alpha $a_{1}$-adrenergic receptor blocking properties, the duration of which is dose-dependent. The specific $S_{2}$-serotonergic receptor antagonist ritanserin does not affect blood pressure, but amplifies the blood pressure lowering effect of the alpha ${ }_{1} /$ alpha $_{2}$-adrenergic receptor blocker phentolamine. It is concluded that per and postoperative hypertension may be effectively treated by means of simultaneous blockade of alpha $a_{1}$-adrenergic and $\mathrm{S}_{2}$-serotonergic receptors. Ketanserin combines these properties.

In the last clinical study (chapter 10), in which the same model as described in chapter 9 is used, ketanserin appeares to be an arterial and venous vasodilator, as opposed to the calcium antagonist nifedipine, recently recommended as antihypertensive agent, which induces only arterial vasodilatation. Ketanserin may be preferred in the treatment of these patients, because venous vasoconstriction develops during and following cardiopulmonary bypass.

In chapter 1.1 the results, as obtained in the above mentioned studies, are discussed in general. Ketanserin is effective in the treatment of postoperative hypertension following coronary surgery, but it is not possible to completely prevent per and postperative hypertension by the continuous infusion of the compound. Unlike sodium nitroprusside ketanserin does not induce reflex tachycardia and an increase in pulmonary shunt fraction. Ketanserin improves peroperative diuresis. The compound is a potent arterial and venous vasodilator. Ketanserin appears to possess both $\mathrm{S}_{2}$-serotonergic and alpha-adrenergic receptor blocking properties. The blood pressure lowering effect is maximal at a dose of $10 \mathrm{mg}$, and the duration of the alpha-adrenergic receptor blocking effect is dose- dependent. Also in man blocking of $\mathrm{S}_{2}$-serotonergic receptors amplifies the blood pressure lowering effect of alpha-adrenergic receptor blockade. Ketanserin combines these two properties. It could not be proven that serotonin plays an important role in the development of hypertension during and following heart surgery, but is assumed that it amplifies the vasoconstrictive effect of catecholamines at the level of the microcirculation. 
Chapter 13

\section{Samenvatting}




\section{Samenvatting}

Een belangrijk probleem voor de anaesthesist is de preventie en behandeling van hypertensie tijdens en na hartchirurgie.

In het inleidende hoofdstuk van dit proefschrift wordt een overzicht gegeven van de incidentie en de oorzaken van deze vorm van hypertensie. Er kan een verdeling worden gemaakt tussen hypertensie die ontstaat voor het aansluiten van de hart-long machine (=cardiopulmonale bypass), tijdens cardiopulmonale bypass, in de periode onmiddellijk na het beeindigen van cardiopulmonale bypass en tijdens de postoperative periode in de eerste uren na aankomst in de intensive care unit (ICU). Met name in de periode voor cardiopulmonale bypass is de bestrijding van hypertensie erg belangrijk omdat het kan leiden tot hartspier beschadiging, verhoogd bloedverlies en eventueel een cerebrovasculair accident, met name bij oudere patienten. De belangrijkste oorzaken van hypertensie in deze periode zijn laryngoscopie, intubatie, sternotomie en sternum spreiden. Bij deze handelingen onstaan zogenaamde pressor effecten die leiden tot een significante stijging van de serumspiegels van catecholaminen als adrenaline en noradrenaline, als mede renine en angiotensine. Er wordt ook aannemelijk gemaakt dat serotonine hierbij een rol speelt.

Hypertensie tijdens cardiopulmonale bypass kent andere oorzaken. Hierbij stijgen de catecholamine-concentraties in het bloed met name onder invloed van hemodilutie, hypothermie, hypotensie en het toepassen van niet-pulsatiele bloeddoorstroming. Tijdens cardiopulmonale bypass ontstaat beschadiging van bloedplaatjes, waarbij stoffen als beta-thromboglobuline, platelet factor 4 , thromboxane B2 en mogelijk ook serotonine vrijkomen in het plasma. In de periode onmiddellijk na cardiopulmonale bypass komt hypertensie nauwelijks voor omdat het hart moet herstellen van de ischaemie die tijdens de operatie ontstaat wanneer de aorta afgeklemd wordt. Slechts ten gevolge van extreme perifere vasoconstrictie kan eventueel hypertensie ontstaan.

In de vroege postoperatieve fase in de ICU komt hypertensie veel voor (40-60\% van de coronair chirurgische patienten). Een combinatie van factoren ligt hieraan ten grondslag, zoals de nog steeds verhoogde catecholamine-concentraties, de verlaagde activiteit van de preoperatieve beta-blockade, en rigiditeit ten gevolge van het gebruik van narcotische analgetica ( b.v. fentanyl of sufentanil). Tevens kan de patient ontwaken in deze periode, waarbij de endotracheale tube ernstige irritatie kan veroorzaken, hetgeen kan leiden tot hypertensie. Of serotonine hierbij een rol speelt is onbekend, maar wordt wel vermoed. In deze fase kan hypertensie dezelfde complicaties veroorzaken als in de periode voor cardiopulmonale bypass. Bovendien wordt verondersteld dat de hypertensie aanlei- 
ding kan geven tot vroege afsluiting van de aangelegde coronaire omleidingen.

Omdat perioperatieve hypertensie in het algemeen wordt behandeld met behulp van vaatverwijdende stoffen (vasodilatatoren), wordt vervolgens een overzicht gegeven van de bestaande intraveneuze antihypertensiva waarvan nitroprusside natrium en nitroglycerine de belangrijkste vertegenwoordigers zijn. Moderne antihypertensiva zoals urapidil en adenosine worden besproken, evenals ketanserin, een $S_{2}$-serotonerge receptor antagonist, die effectief bleek bij de behandeling van patienten met bijvoorbeeld essentiele hypertensie.

Hierna volgt een korte beschrijving van het onstaan, het metabolisme en de effecten van serotonine. Serotonine wordt gesynthetiseerd in de chromaffine cellen van de darm. Na vrijzetting wordt de stof vrijwel volledig opgenomen en gemetaboliseerd in de lever. De in het bloed overgebleven thoeveelheid serotonine wordt opgenomen door endotheelcellen. voornamelijk in de long. De kleine hoeveelheid serotonine die de long passeert wordt opgeslagen in de bloedplaatjes, zodat uiteindelijk slechts een zeer kleine concentratie vrij serotonine in het plasma kan worden aangetroffen. Serotonine kan zowel vasodilatatie als vasoconstrictie veroorzaken, afhankelijk van de soort bloedvaten en van de basale tonus. Serotonine vrijgezet uit aggregerende bloedplaatjes veroorzaakt bijvoorbeeld vasoconstrictie in de arterien, een effect dat via $\mathrm{S}_{2}$-serotonerge receptoren verloopt. De door serotonine veroorzaakte vasodilatatie, bijvoorbeeld op arteriolair niveau, verloopt waarschijnlijk via $\mathrm{S}_{1}$-serotonerge receptoren, waarbij zogenaamde "endothelium-derived relaxing factors" (EDRF) een rol spelen. Daarnaast kan serotonine de vasoconstrictieve werking van andere vasoconstrictoren als catecholaminen en angiotensine versterken. Met name door dit mecharisme wordt aan serotonine een rol toegedacht bij het onstaan van hypertensie. In pathologische condities, zoals atherosclerose, pulmonale hypertensie, endotoxische shock en eclampsie, kan een verhoogde activiteit van serotonine worden aangetoond. Tenslotte worden in het laatste gedeelte van het eerste hoofdstuk de doelstellingen van het voorliggende onderzoek omschreven.

In het tweede hoofdstuk wordt een kort overzicht gegeven van de pharmacologie van ketanserin. Ketanserin is een specifieke $S_{2}$-serotonerge receptor blocker met alpha ${ }_{1}$-adrenerge receptor blockerende eigenschappen. De stof heeft geen $S_{1}$-serotonerge receptor antagonerende werking. Het is een quinazolinederivaat, met een halfwaardetijd van 15 uur. Ketanserin wordt voornamelijk afgebroken in de lever tot niet-werkzame metabolieten. De belangrijkste toepassing betreft de antihypertensieve werking, met name bij patienten met essentiele hypertensie, preeclampsie. pulmonale hypertensie en neurogene hypertensie. Tevens vindt het een 
toepassing bij perifeer vaatlijden zoals bij de ziekte van Raynaud, ziekte van Burger en diabetes mellitus. De antihypertensieve werking van ketanserin werd voor de aanvang van dit proefschrift aan verschillende mechanismen toegeschreven zoals een louter $\mathrm{S}_{2}$-serotonerge receptor blockade, een louter alpha ${ }_{1}$-adrenerge receptor blockade, een combinatie van beide of een centrale sympathico-inhibitie.

Het klinische gedeelte van de thesis begint met een overzicht van de toegepaste technieken op het gebied van anaesthesie, chirurgie, cardiopulmonale bypass en algemene postoperatieve behandeling (hoofdstuk 3).

De eerste klinische studie (hoofdstuk 4) betreft een dubbelblinde, prospectieve studie, waarbij ketanserin of het oplosmiddel van ketanserin peren postoperatief als continu infuus worden toegediend bij patienten die een coronaire bypass operatie ondergaan en waarbij veranderingen in de haemodynamiek en de hormonale plasma spiegels worden gemeten. Tevens worden de gebruikte hoeveelheden fentanyl en nitroglycerine vastgesteld, evenals de peroperatieve diurese. De resultaten tonen aan dat ketanserin tijdens verschillende fasen van de studie een lagere bloeddruk, hartfrequentie en cardiac output, en een hogere perifere weerstand veroorzaakt dan het oplosmiddel van ketanserin. In beide groepen blijken de plasma spiegels van de catecholaminen, renine en angiotensine tijdens en na de operatie significant te stijgen, maar de serotonine-concentraties veranderen niet significant. In de ketanserin-group blijkt de perifere (huid) temperatuur hoger en de diurese groter te zijn, hetgeen wordt toegeschreven aan een mogelijk specifiek $S_{2}$-serotonerge receptor antagonisme met betrekking tot deze orgaansystemen. Tenslotte wordt aangetoond dat tijdens de infusie van ketanserin lagere doseringen fentanyl en minder frequente toediening van nitroglycerine nodig zijn om hypertensieve fasen te bestrijden.

In hoofdstuk 5 wordt in een open studie aangetoond dat ketanserin effectief is in de behandeling van postoperatieve hypertensie na coronair chirurgie. De bloeddrukdaling komt tot stand via verlaging van de perifere weerstand waarbij opvalt dat tijdens de behandeling met ketanserin de hartfrequertie niet stijgt, hetgeen een significante daling veroorzaakt van de triple index (het produkt van systolische bloeddruk, hartfrequentie en linker atrium druk), een maat voor het zuurstofverbruik van het hart.

In hoofdstuk 6 worden de resultaten uit hoofdstuk 5 getoetst door middel van een prospectief dubbelblind onderzoek bij een vergelijkbare groep patienten. Ketanserin blijkt bij significant meer patienten de bloeddruk te verlagen dan het oplosmiddel van ketanserin.

In hoofdstık 7 wordt ketanserin vergeleken met nitroprusside natrium, het meest gebruikte intraveneuze antihypertensivum, bij een vergelijkbare 
groep patienten als in hoofdstuk 5 en 6 . Beide substanties zijn effectief in het verlagen van de bloeddruk. In tegenstelling tot ketanserin blijkt nitroprusside matrium reflex tachycardie en een toename van de pulmonale shunt fractie te veroorzaken. Waarschijnlijk berust dit laatste verschil op het al dan niet intact laten van de hypoxische pulmonale vasoconstrictie.

Ketanserin wordt in hoofdstuk 8 vergeleken met nitroprusside natrium bij de behandeling van pulmonale hypertensie bij patienten die klepchirurgie hebben ondergaam en waarbij meestal sprake is van een reeds bestaande pulmonale dysfunctie ten gevolge van chronische decompensatio cordis. Beide vasodilatatoren blijken effectief te zijn in het verlagen van de pulmonale weerstand. Ook in deze studie blijkt nitroprusside natrium de pulmonale shunt fractie significant te verhogen, dit in tegenstelling tot ketanserin.

Om het werkingsmechanisme van ketanserin verder te analyseren wordt gebruik gemaakt van het model van cardiopulmonale bypass (hoofdstuk 9), omdat dit de mogelijkheid biedt de effecten van geneesmiddelen op de perifere circulatie te bestuderen met uitsluiting van reflexmatige beinvloeding door het hart. Hierbij blijkt dat het acute bloeddrukverlagend effect van ketanserin dosis-afhankelijk is, met een maximaal effect bij een dosis van $10 \mathrm{mg}$. Tevens blijkt dat ketanserin een alpha drenerge receptor blockerende werking bezit, waarbij de duur van de alpha-blockade dosis afhankelijk is. Tenslotte blijkt dat de specifieke $S_{2}$-serotonerge receptor antagonist ritanserin geen invloed uitoefent op de bloeddruk, maar wel een amplificerende werking heeft op het bloeddrukverlagende effect van de alpha $\mathrm{a}_{1}$ /alpha $\mathrm{a}_{2}$-adrenerge receptor blocker phentolamine. Er wordt geconcludeerd dat per-en postoperatieve hypertensie effectief behandeld kan worden met behulp van de geiijktijdige blockade van alpha $\mathrm{a}_{1}$-adrenerge en $\mathrm{S}_{2}$-serotonerge receptoren.

In de laatste klinische studie (hoofdstuk 10), uitgevoerd in hetzelfde model als beschreven in hoofdstuk 9 , wordt aangetoond dat ketanserin zowel een arteriele als veneuze vasodilatator is, maar dat de calcium antagonist nifedipine, recent als antihypertensivum aanbevolen, slechts een arteriele vasodilatator is. Omdat tijdens en na cardiopulmonale bypass veneuze vasoconstrictie optreedt, heeft ketanserin bij de behandeling van deze patienten de voorkeur.

In hoofdstuk 11 worden algemene conclusies getrokken uit de beschreven studies. Ketanserin is effectief in de behandeling van postoperatieve hypertensie na coronair chirurgie, maar het is niet mogelijk om met behulp van een continu infuus van ketanserin per- en postoperatieve hypertensie te voorkomen. Ketanserin veroorzaakt geen reflex tachycardie en geen stijging van de pulmonale shunt fractie. Ketanserin verbetert de peroperatieve diurese. De stof is een krachtige arteriele en verieuze vaat- 
verwijder. Ketanserin blijkt, naast zijn bekende specifieke $S_{2}$-serotonerge ook alpha-adrenerge receptor blockerende eigenschappen te bezitten, waarbij de bloeddrukverlagende werking een maximum kent bij $10 \mathrm{mg}$, en de duur van de alpha-adrenerge receptor blockade dosis afhankelijk blijkt te zijn. Tevens wordt aangetoond dat blockade van $\mathrm{S}_{2}$-serotonerge receptoren het effect van alpha-receptor blockade ook in de mens amplificeert. Tenslotte moet opgemerkt worden dat niet duidelijk kon worden aangetoond dat serotonine een belangrijke rol speelt bij het ontstaan van hypertensie tijdens en na hartchirurgie, maar mogelijk op het niveau van de microcirculatie de vasoconstrictieve werking van catecholaminen versterkt. 
Chapter 14

\section{References}




\section{References}

Abel RM, Buckley MJ, Austen WG, Barnett GO, Beck CH, Fischer JE: Etiology. incidence and prognosis of renal falure following cardiac operations. J Thorac Cardiovasc Surg 1976;71:323m333

Abela M. McArdle B, Qureshi M. Heparin-enhanced ADP-induced platelet aggregation in patients undergoing cardiopulmonary bypass surgery. Perfusion 1986; 1" 175 "178.

Adams AP, Clarke TNS, Edmonds-Seal J, Foxe P, Prys-Roberts C, Roberts JG. The effects of sodium nitroprusside on myocardial contractility and haemodynamics. $\mathrm{Br} J$ Anaesth 1974;46:807-817

Aken van $H$, Puchstein $C$, Fitch W, Graham Dl. Haemodynamic and cerebral effects of ATP-induced hypotension. Br J Anesth 1984a;56:1409-1415


antihypertensive agent with specific 5-HT 2 -receptor blocking activity, on intracranial pressure Crit Care Med 1984b;12:4-7

Ali J, Weisel RD, Layug AB, Kripke $B J_{1}$ Hechtman $\mathrm{HB}$. Consequences of postoperative alterations in respiratory mechanisms. Am J Surg 1974;128:376-382

Amery A, Fagard R, Fiocchi R, Lijnen P, Staessen J, Vanhees L. Ketanserin: a new hypotensive drug? J Cardiovasc Pharmacol 1985;7(suppl 7):176-182

Anderson $\mathrm{GH}$, Hellums JD, Moake J, Alfrey Jr CP. Platelet response to shear stress: changes in serotonin uptake, serotonin release, and ADP induced aggregation. Thromb Res 1978; 13:1039-1043

Anger $C_{1}$ Carter $J$, Prys-Roberts $C$. Ketanserin and postoperative hypertension following cardiopulmonary bypass. Brit J Anaesth 1985;57:339P

Anjou-Lindskog $E$, Broman L, Broman $M_{1}$ Holmgren A. Effects of oxygen on centra: haemodynamics and $V / Q$ distribution after coronary bypass surgery. Acta Anaesthesiol Scand 1983;27:378-384

Anton AH, Gravenstein JS, Wheat MW. Extracorporeal circulation and endogenous epinephrine and norepinephrine in plasma, atrium, and urine in man. Anesthesiology $1964 ; 25: 262-269$

Arnett EL, Watts DT. Catecholamine excretion in men exposed to cold. J Appl Physiol $1960 ; 15: 499-500$

Arnold WP, Longnecker DE, Epstein RM. Photodegradation of sodium nitroprusside: biologic activity and cyanide release. Anesthesiology 1984,61:254-260 
Austen WG, Coming HB, Moran JM, Sanders CA, Scanmell JG. Cardiac

haemodynamics immediately following mitral valve surgery. I Thorac Cardiovasc Surg $1966,51: 468-473$

Axelrod J, Inscoe JK. The uptake and binding of circulating serotomin and the effect of drugs. J Pharmacol Exp Ther 1963;141:161-165

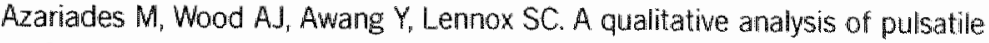
perfusion: effects on cortisol response to cardiopumonary bypass surgery. Thorac Cardiowasc Surgeon 1986;34:163-167

Bachmann F, McKenna R, Cole ER, Najafi H. The hemostatic mechanism after open-heart surgery. I: Studies on plasma coagulation factors and fibrinolysis in 512 patients after extracorporeal circulation. I Thorac Cardiovasc Surg 1975; $70: 76-85$

Bailey DR, Miller ED, Kaplan JA, Rogers PW. The renin-angiotensin-aldosteron system during cardiac surgery with morphine-nitrous-oxide anesthesia. Anesthesiology $1975 ; 42: 538-544$

Bailey PL, Wilbrink J, Zwanikken P, Pace NL, Stanley TH. Anesthetic induction with fentanyl. Anesth Analg 1985;64:48-53

Balasaraswathi K, Glisson SN, El-Etr AA, Roque P. Serum epinephrine and norepinephrine during valve replacement and aorta-coronary bypass. Can Anaesth Soc J 1978;25:198-211

Balasaraswathi K, Glisson SN, El-Etr AA Mummaneni N. Haemodynamic and catecholamine response to isoflurane anaesthesia in patients undergoing coronary artery bypass surgery. Can Anaesth Soc J 1982;29:533-538

Barclay SA, Bennett D. The direct measurement of plasma colloid osmotic pressure is superior to colloid osmotic pressure derived from albumin or total protein. Int Care Med 1987;13:114-118

Barrer MJ, Ellison N. Platelet function. Anesthesiology 1977:46:202-211

Bazaral MG, Wagner R, Abi-Nader E, Estatanous FG. Comparison of the effects of 15 and $60 \mu \mathrm{g} / \mathrm{kg}$ fentanyl used for induction of anesthesia in patients with coronary artery disease. Anesth Analg 1985;64:312-318

Bedford RF, Marshall WK. Cardiovascular response to endothracheal intubation during four anaesthetic techniques. Acta Anaesthesiol Scand 1984;28:563-566

Bell WR, Tomasula PA, Alving BM, Duffy TP. Thrombocytopenia occurring during the administration of heparin. Ann Intern Med 1976;85:155-159 
Bentley KI, Henry PD. Serotonin, a potent constrictor of human coronary artery. Circulation 1981,64:44:64

Bernard GR, Brigham KL. Puimonary edema. Pathophysiological mechanisms and approaches to therapy. Chest 1986;89.594-600

Berthelsen P, Haxholdt OSt, Husum B, Rasmussen JP. PEEP reverses nitrogiycerin-induced hypoxemia foilowing coronary artery bypass surgery. Acta Anaesthesiol Scand $1986 ; 30: 243-246$

Best N, Sinosich MJ, Teisner B. Grundzinskas JG. Fisher McD Complement activation during cardiopulmonary bypass by heparin-protamine interaction. Br J Anaesth $1984,56: 339-343$

Bevan $J_{\text {s }}$ Heptinstall $S$. Effects of ketanserin and mepyramine on platelet aggregation and on the uptake of 5-hydroxytryptamine into platelets. Thromb Res $1983,30: 415-423$

Bick RL, Schmalhorst WR. Arbegast NRR. Alterations of hemostasis associated with cardiopulmonary bypass. Semin Thromb Hemost 1976;3:59-82

Bidwail AV, Rogers CR. Preoperative stellate-ganglion blockade to prevent hypertension following coronary artery operations. Anesthesiology 1979;51:345-347

Bishop MJ, Cheney FW. Vasodilators worsen gas exchange in dog oleic-acid lung injury. Anesthesiology 1986;64:435-439

Blackshear JL, Orlandi C, Garnic JD, Hollenberg NK. Differential large and small vessel responses to serotonin in the dog hindlimb in vivo: role of the $5 \mathrm{HT}_{2}$ receptor. J Cardiovasc Pharmacol 1985;7:42-49

Blackshear JL, Orlandi C. Hollenberg NK. Serotonin and the renal blood supply: role of prostaglandins and the $5 \mathrm{HT}_{2}$ receptor. Kidney Int 1986;30:304-310

Bloor BC, Fukunaga AF, Ma C, Flacke WE, Ritter d, Van Etten A, Olewine S. Myocardial hemodynamics during induced hypotension: a comparison between sodium nitroprusside and adenosine triphospate. Anesthesiology 1985;63:517-525

Boldt $\downarrow$, Bormann $\vee \mathrm{B}$, Kling $\mathrm{D}$, Gorlach $\mathrm{G}$, Hempelmann $\mathrm{G}$. Influence of wentilation with varying endexpiration pressure on the extravascular lung water volume following extracorporeal circulation. Anaesthesist $1985 ; 34: 287-293$

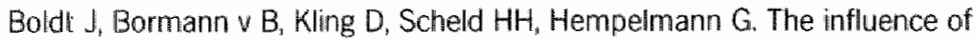
extracorporeal circulation on extravascular lung water in coronary surgery patients. Thorac Cardiovasc Surgeon 1986;34:110-115

Boldt $J_{n}$ Bormann v $B$, Kling $D$, Gorlach $G$, Hempelmann $G$. Influence of intravenous nimodipine on haemodynamics in cardiac patients. Anaesthesist 1985;34:229-235 
Boldt J, Muller $\mathrm{H}_{v}$ Borner U, Kling $\mathrm{D}$, Moosdorf $\mathrm{R}$, Hempelman $\mathrm{G}$. Studies on the isolated influence on the wascular system by warious blood pressure increasing dings during extracorporeal circulation in man. Anaesthesist 1986;35:93-98

Bolt GR, Saxena PR. Cardiovascular profile and hypotensive mechanism of ketanserin in the rabbit. Hypertension 1985;7:499-506

Bolen JL, Alderman EL. Hemodynamic consequences of afterload reduction in patients with chronic aortic regurgitation. Circulation $1976 ; 53879-883$

Bolling SF, Flaherty JT, Potter AM, Gardner TJ. Propranolol-induced postoperative hypertension following coronary artery bypass grafting. I Thorac Cardiovasc Surg $1984 ; 87: 112-119$

Bonchek Li. Indications for surgery of the mitral valve. Am J Cardiol 1980;46:155-158

Boonstra PW imhoff wan GW, Eysman L, Kootstra GJ, Homan wan der Heide JN, Karliczek GF, Wildevuur CRH. Reduced platelet activation and improved hemostasis after controlled cardiotomy suction during clinical membrane oxygenator perfusions. J Thorac Cardiovasc Surg 1985;89:900-906

Bovill JG, Warren PJ, Schuller JL, van Wezel HB, Hoeneveld MH. Comparison of fentanyl, sufentanil, and alfentanil anesthesia in patients undergoing valvular heart surgery. Anesth Arlalg 1984a;63:1081-1086

Bovill JG, Sebel PS, Stanley TH. Opioid analgesics in anesthesia: with special reference to their use in cardiovascular anesthesia. Anesthesialogy $1984 b ; 61: 731-755$

Bowman WC, ed. The pharmacology of neuromuscular function. Bristol: John Wright and Sons Ltd, 1980:105

Braunwald E. Control of myocardial oxygen consumption: physiologic and clinical considerations. Am 』 Cardiol 1971;27:416-432

Brazenor RM, Angus JA. Actions of serotonin antagonists on dog coronary artery. Eur J Pharmacol 1982;81:569-576

Breuer J, Meschig R Breuer HWM, Arnold G. Effects of serotonin on the cardiopulmonary circulatory system with and without $5-\mathrm{HT}_{2}$-receptor blockade by ketanserin. J Cardiovasc Pharmac 1985;7(suppl 7):64-66

Breuer $J$, Meschig $R$, Arnold $G$. Effects of ketanserin on the serotonin-induced pulmonary hypertension in dogs. Eur J Physiol 19866:406 (suppl):R47

Brody WR, Kosek JC. Angell WW. Changes in vein grafts following aortoncoronary bypass induced by pressure and ischemia. I Torac Cardiovasc Surg 1972;64:847-854 
Brown III CH, Leverett LB, Lewis CW. Alfrey Jr CP, Hellums JD. Morphological, biochemical, and functional changes in hunman platelets subjected to shear stress. J Lab Clin Med $1975,86,462-471$.

Brown BR, Gandolfi AJ. Adverse effects of volatile anaesthetics. Br J Anaesth $1987: 59: 14-23$

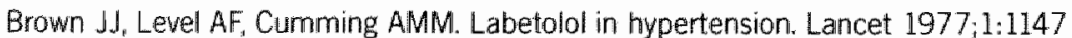

Cashman JN, Thompson MA, Bennett A. Influence of ketanserin pretreatment on the haemadynamic responses to sternotomy. Anaesthesia 1986;41:505-510

Casthely PA, Jablons M, Griepp RB, Ergin MA, Goodman K. Ketanserin in the preoperative and intraoperative management of a patient with carcinoid tumor undergoing tricuspid valve replacement. Amesth Analg 1986;65:809-811

Casthely PA, Villanueva R, Rabinowitz L, Gandhi P, Litwak B, Fyman P. Intrapulmonary shunting during deliberate hypotension with nifedipine, diltiazem and labetalol in dogs. Can Anaesth Soc J 1985;32:119-123

Cattaneo SM, Leier CV. Intravenous isosorbide dinitrate in the management of acute hypertension fiollowing cardiopulmonary bypass. Ann Thorac Surg 1982;33:345-353

Cavarocchi NC, Pluth JR, Schaff HV, Orszulak TA, Homburger HA, Solis E, Kaye MP, Clancy MS, Kolff J, Deeb GM. Complement activation during cardiopulmonary bypass. I Thorac Cardiovasc Surg 1986;91:252-258

Chambers DJ, Karimzandi N, Braimbridge MV, Dunham J, Brooks $F_{4}$ Quiney J, Slavin B. Hormonal and electrolyte responses during and after open heart surgery. Thorac Cardiovasc Surgeon 1984,32:358-364

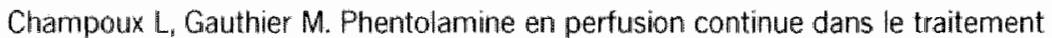
d'une hypertension arterielle severe associee a un neuroblastome. Can Anaesth Soc J $1984,31: 206-209$

Chenoweth DE, Cooper SW, Hugli TE, Stewart RW, Blackstone EH, Kirklin JW. Complement activation during cardiopulmonary bypass. N Eng J Med $1981 ; 304: 497-503$

Chernow $B$, Lake $C R$, Zaritsky A, Finton $C K$, Casey L, Rainey TG, Fletcher JR. Sympathetic nervous system "switch off" with severe hypothermia. Crit Care Med $1983 ; 11: 677-680$ 
Christakis GT, Weisel RD, Fremes SE, Teah KK, Skalenda P, Tong CP, Azuma JY.

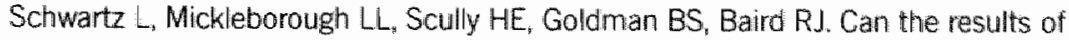
contemporary aortic valve replacement be improved? \Thorac Cardiovasc Surg 1986; $92: 37-46$

Clark RE, Christlieb IY, Henry PD. Nifedipine: a myocardial protective agent. Am J Card $1979,44: 825-831$

Clarke AD, Jackson PW. Postoperative care of patients undergoing cardiopulmonary bypass. Br J Anaesth 1971;43:248-260

Church J, Zsoter TT. Calcium antagonistic drugs: mechanisms of action. Can J Physiol Pharmacoll 1980;58:254-264

Cohen ML., Fuller RW, Wiley KS. Evidence for $5-\mathrm{HT}_{2}$ receptors mediating contraction in wascular smooth muscle. I Pharmacol Exp Ther 1981;218:421-425

Cohen RA, Shepherd JT, Vanhoutte PM. Inhibitory role of the endothelium in the response of isolated coronary arteries to platelets. Science $1983 a ; 221: 273-274$

Cohen RA, Shepherd JT. Vanhoutte PM. 5-Hydroxytryptamine can mediate endothelium-dependent relaxation of coronary arteries. Am J Physiol $1983 b ; 245: 1077-1080$

Cohen RA, Coffman JD. Digital vasospasm: the pathophysiology of Raynaud's phenomenon. Int Angioll 1984;3:47-55

Cohn JN, Franciosa JA. Vasodilator therapy of cardiac failure. N Eng J Med $1977 ; 297: 27-31$

Comroe JH, Forster RE, Dubois AB, Briscoe WE, Carlsen E. The Lung. In Year Book. Chicago: Medical Publishers, 1968, pp 344-379

Cooper TJ, Clutton-Brock TH, Jones S, Tinker J, Treasure T. Factors relating to the develonment of hypertension after cardiopulmonary bypass. $\mathrm{Br}$ Heart $\mathrm{J}$ $1985 ; 54.91-105$

Copeland IW, Bentley GA. A possible central action of prazosin and ketanserin to cause hypotension. J Cardiovasc Pharmacol 1985;7:822-825

Coriat P. Imtravenous nitroglycerin dosage to prevent intraoperative myocardial ischemia during noncardiac surgery. Anesthesiology 1986;64:409-410

Coriat P, Daloz M, Bousseau D, Fusciardi J, Echter E, Viars P. Prevention of intraoperative myocardial ischaemia during noncardiac surgery with intravenous nitroglycerin. Anesthesiology 1984,61:193-196 
Cork RC, Hameroff SR, Weiss JL. Effects of halothane and fentanyl anesthesia on plasma beta-endorphin immunoreactivity during cardiac surgery. Anesth Analg $1985 ; 64: 677-80$

Cortese DA. Pulmonary function in mitral stenosis. Mayo Clin Proc 1978;53:321-326

Costa JL. Murphy DL. Alterations in human platelet serotonin uptake following the addition of thrombin and A 23187. Thromb Haemostas 1977;37:177-179

Crul JF. Relaxant drugs: from native drugs to the selective agents of today. Acta Anaesth Scand 1982;26:409-415

Cummings SA, Groszmann RJ, Kaumann AJ. Hypersensitivity of mesenteric veins to 5-hydroxytryptamine- and ketamserin-induced reduction of portal pressure in portal hypertensive rats. $\mathrm{Br}$ J Pharmac 1986;89:501-513

Curro FA, Greenberg $S$, Verbeuren TS, Vanhoutte PM. Interaction between alpha-adrenergic and serotonergic activation of canine saphenous veins. J Pharmacol Exp Ther 1978;207:936-949

Dahlgren $N$, Messeter $K$. Treatment of stress response to laryngoscopy and intubation with fentanyl. Anaesthesia 1981;36:1022-1025

D'Ambra MN" LaRaia PJ, Phibin DM, Watkins WD, Hilgenberg AD, Buckley MJ. Prostaglandin $E_{1}$. A new therapy for refractory right heart failure and pulmonary hypertension after mitral valve replacement. I Thorac Cardiovasc Surg $1985 ; 89: 567-572$

Damen $\rfloor$, Bolton D. A prospective analysis of 1400 pulmonary artery catheterizations in patients undergoing cardiac surgery. Acta Anaesth Scand 1986;30:386-392

De Clerck F. Nueten van JM. Platelet-mediated vascular contractions: inhibition of the serotonergic component by ketanserin. Thromb Res 1982a;27:713-727

De Clerck F, David JL, Janssen PAJ. Irhibition of 5-hydroxytryptamine-induced and amplified human platelet aggregation by ketanserin (R41468), a selective $5-H T_{2}$ receptor antagonist Agents Actions 1982b; 12:388-397

De Clerck $F_{n}$ David $J L$, Janssen PAJ. Serotonergic amplification mechanisms in blood platelets. in: 5-Hydroxytryptamine in Peripheral Reactions, ed F. De Clerck and P.M. Vanhoutte $1982 \mathrm{C}_{\mathrm{i}}$ pp. $83-94$

De Clerck F, De Brabander M, Neels $H$. Vandevelde $V$. Direct evidence for the contractile capacity of endothelial cells. Thromb Res 1981;23:505-520

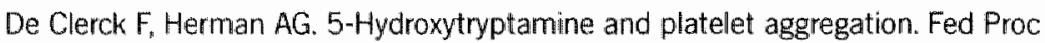
$1983 ; 42: 228-232$ 
De Clerck $F$, Xhonneux $B$, Leysen $J_{\text {, Janssen PA. Evidence for functional } 5-\mathrm{HT}}$ receptor sites on human blood platelets. Biochem Pharmacol 1984a;33:2807-2811.

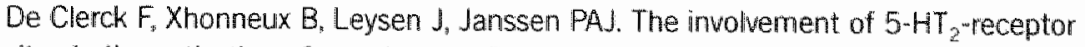
sites in the activation of cat platelets. Thromb Res $1984 \mathrm{~b}_{i} 33: 305-321$

De Clerck $F_{0}$ van Nueten JM, Reneman RS. Platelet-vessel wall interactions: implication of 5-hydroxytryptamine. A review. Agents Actions 1984c;15:612-626

De Cree J, Hoing $M_{A}$ De Ryck $M$, Symoens J. The acute antihypertensive effect of ketanserin increases with age. J Cardiovasc Pharmac 1985;7/suppl 7):126 127

De Cree J, Leempoels J, Cock de W, Geukens $H$, Verhaegen $H$. The antihypertensive effects of a pure and selective serotonin-receptor blocking agent (R41468) in elderly patients. Angiology 1981a;32:137-144

De Cree J, Leempoels J, Geukens H, Cock de W, Verhaegen $H$. The antihypertensive effects of ketanserin (R41468), a nowel 5-hydroxytryptamine-blocking agent, in patients with essential hypertension. Clin Sci 1981b;61:S473-S476 De Cree J, Verhaegen $H_{3}$ Symoens $J$. Acute blood pressure lowering effect of ketanserin. Lancet 1981c:23:1161-1162

De Jong JCF, ten Duis HJ, Smit Sibinga CT, Wildevuur CRH. Hematologic aspects of cardiotony suction in cardiac operations, J Thorac Cardiowasc Surg $1980 ; 79: 227-236$

De Lange $\mathrm{S}$, Boscoe MJ, Stanley $\mathrm{TH}_{4}$ Pace $\mathrm{N}$. Comparison of sufentanil- $\mathrm{O}_{2}$ and fentanyl $-\mathrm{O}_{2}$ for coronary artery surgery. Anesthesiology $1982 ; 56: 112-118$

De Leeuw PW, Van Es PN, Van Soest GAW, Tchang PT, Birkenhager WH. Effects of chronic oral treatment with ketanserin, a new $5-4 T_{2}$ antagonist in essential hypertension. J Hypertension 1983;1(suppl 1):379-380

Demos MA, Strauss Rd, Schnipper LE, Stuckey JH. Plasma serotonin levels during total cardiopulmonary bypass. J Thorac Cardiovase Surg 1970,60:257 260 Docherty $J R$, Hyland $L$. An examination of 5-hydroxytryptamine receptors in human saphenous vein. $\mathrm{Br}$ J Pharmac 1986;89:77-81

DOliveira M, Sykes MK, Chakrabarti MK, Orchard C, Keslin J. Depression of hypoxic puimonary vasoconstriction by sodium nitroprusside and nitroglycerin. $\mathrm{Br} J$ Anaesth. $1981,53: 11-18$

Dorinsky PM. Whitcomb ME. The effect of PEEP on cardiac output. Chest $1983 ; 84: 210-216$

Drapanas $T$, McDonall JC. The direct removal of portal blood serotonin by the liver. Surg Gynecol Obstet 1963; 116:481-485 
Drummond AH,Gordon U. Rapid, sensitive microassay for platelet 5HT. Thromb Diathes Haemorrh 1974:31:366-367

Drummond AH. Interaction of blood platelets with biogenic amines: Uptake, stimulation and receptor binding. In: Platelets in Biology and Pathology, ed Gordon, 1976; pp 203-239. Elsevier North Holland Biomedical Press, New York.

Dungen van den JJAM, Karliczek GF, Brenken U, Homan van der Heide JN, Wildevuur CRH. Clinical study of blood trauma during perfusion with membrane and bubble oxygenators. I Thorac Cardiowasc Surg 1982;83:108-116

Eika C. On the mechanism of platelet aggregation induced by heparin, pratamine and polybrene. Scand J Haematol 1972;9:248-257

El-Etr A, Glisson SN. Alpha-adrenergic blocking agents. Int Anesth Clin $1978 ; 16: 239-259$

Ellison N, Edmunds LH, Colman RW. Platelet aggregation following heparin and protamine administration. Anesthesiology 1978;48:65-68

Ellmaver $S_{i}$ Brandt $L$. The influence of barbiturates on the haemadynamics during extra-corporeal circulation: thiopental vs methohexital. Anaesthesist 1986;35:414-418

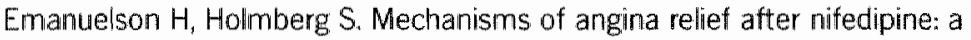
haemodlynamic and myocardial metabolic study. Circulation 1983;68:124-130

Engelman RM, Haag B, Lemeshow S, Angelo A, Rousou JH. Mechanism of plasma catecholamine increases during coronary artery bypass and valve procedures.

I Thorac Cardiowasc Surg 1983;86:608-615

Erne P, Pletscher A. Rapid intracellular release of calcium in human platelets by

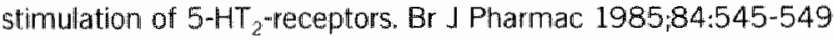

Erspamer $V_{\text {: Asero }} B$. Identification of enteramine, the specific hormone of the enterochromaffin cell system, as 5-hydroxytryptamine. Nature (Lond.)

1952:169:800-801

Estafanous FG $_{v}$ Urzua J, Yared JP, Zurick AM, Loop FD, Tarazi RC. Pattern of haemodynamic alterations during coronary artery operations. J Thorac Cardiovasc Surg 1984;87:175-182

Estafanous FG, Tarazi RC. Systemic arterial hypertension associated with cardiac surgery. Am J Cardiol 1980;46:685-694

Estafanous FG, Tarazi RC, Buckley $\mathrm{S}$, Taylor PC. Arterial hypertension in the immediate postoperative period after valve replacement. Brit Heart J

$1978 ; 40: 718-724$ 
Estafanous FG, Tarazi RC, Viljoen JF, EI Tawil MY. Systemic hypertension following myocardial revascularization. Am Heart I 1973;85:732 738

Fagard R. Fiocchi R, Lijnen P, Staessen J, Moerman E, Schaepdryver ADF, Amery A. Haemodynamic and humoral responses to chronic ketanserin treatment in essential hypertension. Br Heart J 1984a;51:149-156

Fagard R, Cattaert A, Lijnen P, Staessen J, Vanhees L, Moerman E, Amery A. Responses of the systemic circulation and of the renin-angiotensin-aldosterone system to ketanserin at rest and exercise in normal man. Clin Sci 1984b;66:17-25

Fahmy NR, Soter NA. Effects of trimethaphan on arterial blood histamine and Systemic hemodynamics in humans. Anesthesiology 1985;62:562-566

Farmer JB, Kennedy 1, Levy GP, Marshall RJ. Pharmacology of labetolol, a drug which blocks both alipha* and beta-adrenoceptors. Br J Pharmacol 1972;45:660-675

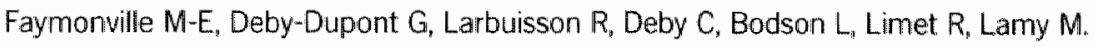
Prostaglandin $E_{2}$, prostacyclin, and thromboxane changes during nonpulsatile cardiopulmonary bypass in humans. J Thorac Cardiovasc Surg 1986;91:858-866

Feddersen K. Prostacyclin infusion during cardiopulmonary bypass. Thesis,1985

Feniuk W, Humphrey PPA, Watts. Further evidence for the heterogenity of vascular receptors for 5-hydroxytryptamine. Br J Pharmac 1983;79:296P

Ferrari HA, Gorten RJ, Talton $\mathrm{IH}$. The action of droperidol and fentanyl on cardiac output and related hemodynamic parameters. South Med $\Downarrow 1974 ; 67: 49-53$

Fischerstrom A, Ohavist G, Settergren G. Comparison of fentanyl and halothane as supplement to nitrous-oxide-axygen anaesthesia for coronary artery surgery. Acta Anaesthesiol Scand 1985;29:16-21

Flaherty IT, Magee PA, Gardner TL, Potter A, MacAllister NP. Comparison of intravenous nitroglycerin and sodium nitroprusside for treatment of acute hypertension developing after coronary artery bypass surgery. Circulation $1982 ; 65: 1072-1077$

Forbes AM, Dally FG. Acute hypertension during induction of anaesthesia and endotracheal intubation in normotensive man. $\mathrm{Br}$ J Anaesth 1970;42:618-624

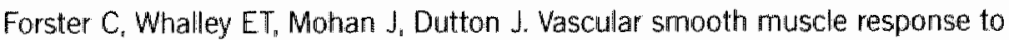
fibrinogen degradation products and 5-hydroxytryptamine: Possible role in cerebral vasospasm in man. Br J Clin Pharmacol 1980:10:231 236

Fouad FM, Estafanous FG, Tarazi RC. Hemodynamics of postmyocardial revascularization hypertension. Am J Cardiol 1978;41:564-569 
Fox EJ, Sklar GS, Hill CH, Villanueva R, King BD. Complications related to the pressor response to endotracheal intubation. Anesthesiology 1977,4:47524-525

Fox WC, Fox EJ, Crandell DL. Neurolept-analgesia for heart and major surgery. Archi Surg 1967:94:102-106

Fozard JR. Mechanism of the hypotensive effect of ketanserin. J Cardiovasc Pharmacol 1982,4:829-838

Fragen RJ, Shanks CA, Molteni A, Avram MJ. Effects of etomidate on hormonal responses to surgical stress. Anesthesiology 1984;61:652-656

Franklin $\mathrm{C}$, Nightingale $S_{\text {, }}$ Mamdani B. A randomized comparison of nifedipine and sadium nitroprusside in severe hypertension. Chest 1986;90:500-503

Fremes $S E$, Weisel RD, Baird RJ, Mickleborought $L L$, Burns $R J$, Teasdale $S J$, Ivanov J, Seawright S., Madonik MM, Mickle DAG, Scully HE, Goldman BS, McLaughin PR. Effects of postoperative hypertension and its treatment. J Thorac Cardiowasc Surg $1983 ; 86: 47-56$

Fremes SE, Weisel RD, Baird RJ, Mickleborough LL, Burns RJ, Teasdale SJ, Frenken M, Kaumann AJ. Interaction of ketanserin and its metabolite ketanserinol with $5 \mathrm{HT}_{2}$-receptors in pulmonary and coronary arteries of calf. Naunyn-Schmiedeberg's Arch Pharmacol 1984;326:33:4-339

Frick MH. Influence of 5-hydroxytryptamine on renal function in extracorporeal circulation. Nature $1960_{i}$ 187:609-613

Friedman LI, Liem H, Grabowski EF, Leonard EF, McCord CW Inconsequentiality of surface properties for initial platelet adhesion. Trans Am Soc Artif Int Organs $1970 ; 16: 63-73$

Fukunaga AF, Olevine SK, Van Etten AP. Hemodynamic effects of ATP' and nitroprusside. Anesthesiology 1981:57:13

Furukawa $Y$, Saegusa $K$, Ogiwara $Y$, Chiba $S$. Effects of ketanserin on the pacemaker activity and contractility in the isolated, blood-perfused dog atrium. J Cardiovasc Phaimacol 1986;8:967-972

Fyman Ph, Cottrell J, Kushins L, Casthely PA. Vasodilator therapy in the perioperative period. Can Anaesth Soc $1986,33: 629-643$

Gale GD, Teasdale SJ, Sanders DE. Pulmonary atelectasis and other respiratory complications after cardiopulmonary bypass and investigations of aetiological factors. Can Anaesth Soc J 1979;26:15-20 
Gall WE, Clarke WR, Dioty DB. Vasomotor dynamics associated with cardiac operations. Vemous tone and the effects of vasodilators. I Thorac Cardiovasc Surg $1982 ; 83: 724-731$

Gallagher JD, Measurement of pumonary extravascular water during noncardiogenic pulmonary edema after coronary artery bypass grafting. Crit Care Med $1985 ; 13: 991-992$

Gallagher JD, Moore RA, Jose AB, Botros SB, Clark DL. Prophylactic nitroglycerin infusions during coronary artery bypass surgery. Anesthesiology 1986;64:785-789

Gans. $H$, Kriwit W. Problems in hemostasis during open-heart surgery, IV: On the changes in the blood clotting mechanism during cardiopulmonary bypass procedures. Arn Surg 1962; 155:353-359

Garattini S, Valzelli L. Serotonin. New York, American Elsevier,1965,137*147

Gasic S, Eichler HG, Korn A. Effect of ketanserin on phenylephrine-dependent changes in splanchnic hemodynamics and systemic blood pressure in healtily subjects. J Cardiovasc Pharmac 1985:7:219-223

Geha AS. Acute renal failure in cardiovascular and other surgical patients. Surg Clin North America 1980;60:1151-1166

Gelman $G$, Fowles $K C_{i}$ Smith LR. Regional blood flow during isoflurane and halothane anesthesia. Anesth Analg 1984;63:557-565

Gerson Jl, Allen FB, Seltzer JL, Parker FB, Harkowitz AH. Arterial and venous dilation by nitroprusside and nitroglycerin - is there a difference? Anesth Analg $1982 ; 61: 256-60$

Ghignone $\mathrm{M}$, Quintin L, Duke PC, Kehler $\mathrm{CH}_{3}$ Calvillo O. Elfects of clonidine on narcotic requirements and hemodynamic response during induction of fentanyl anesthesia and endotracheal intubation. Anesthesiology 1986,64:36-42

Giese J, Stockham RJ. Stanley TH, Pace NL, Nelissen RH. Etomidate versus thiopental for induction of anesthesia. Anesth Analg 1985;64:871-876

Gillis CN, Greene NM, Cronau LH, Hammond GL. Pulmonary extraction of 5-hydroxytryptamine and norepinephrine before and after cardiopulmonary bypass in man. Circ Rec 1972,30:666-674

Gillis CN. Pitt BR. The fate of circulating amines within the pulmonary circulation. Annu Rev Physiol 1982;44:269-281 
Goenen MJ, Leenaert L, Petein M, Pouleur $H$, Jaumin P, Tremouroux The effects of tolazoline, nitroprusside, nitroglycerin, isoproterenol and hydralazine on pulmonary circulation early after heart valve replacement. Thorac Cardiovasc Surgeon $1982 ; 30: 253-258$

Gonzalez-Scarano $\mathrm{F}$. Hurting $\mathrm{H}$. Neurologic complications of coronary-artery bypass grafting: case-control study. Neurology 1981;31:1023-1035

Good JT, Wolz JF, Anderson JT, Dreisin RB, Petty Th, L. The routine use of positive end-exspiratory pressure after open heart surgery. Chest 1979:76:397-400

Gould L. Reddy CVR. Phentolamine. Am Heart J 1976;92:397-402

Gralnick HR, Fischer RD. The hemostatic response to open-heart operations. I Thorac Cardiovasc Surg 1971;61:909-913

Graves $\mathrm{CL}$, Downs $\mathrm{NH}$, Browne $\mathrm{AB}$. Cardiovascular effects of minimal analgesic quantities of innovar, fentanyl, and droperidol in man. Anesth Anaig 1975:54:15-22

Greenblatt D., Abernethy DR, Lacniskar $A_{*}$ Harmatz JS, Limjuco RA, Shader Rl. Effect of age, gender, and obesity on midazolam kinetics. Anesthesiology 1984;61:27-35

Griffiths HBA, Whitwam IG. Ketanserin and the cardiovascular system. 1. Modification of the effects of pressor amines in patients undergoing myocardial revascularisation. Anaesthesia 1986a;41:708-711

Griffiths HBA, Whitwam JG. Ketanserin and the cardiovascular system. 2. A study of its effects in patients undergoing myocardial revascularisation. Anaesthesia 1986b;41:712-716

Gunnicker $M_{3}$ Hirche $H$, Nommensen $C C$, Hess W. Haemodynamic profile of isoflurane and neurolept anaesthesia in patients undergoing cononary artery bypass surgery. Anaesthesist $1986 ; 35: 338-344$.

Gustafson $\mathrm{C}$. The central and peripheral circulation during and after sodium nitroprusside induced hypotension in the rat. Br J Anaesth 1984;56:1029-1035

Haisey M. Drug interactions. Br J Anaesth 1987;59:112-123

Hancock EW. Aortic stenosis, angina pectoris, and coronary artery disease. Am Heart J $1977: 93,382-393$

Hardy JF, Boulanger M, Maille JG, Paiement B; Taillefer J, Salhab P, Delorme M. Arterial hypertension following coronary artery surgery: Influence of the narcotic agent used for anaesthesia. Can Anaesth Sac J 1983:30:4:370-376

Harioka T, Hatano Y, Mori K. Toda N. Trimethaphan is a direct arterial wasodilator and an alpha-adrenoceptor antagonist. Anesth Analg 1984;63:290-296 
Harker LA, Malpass TW, Branson ME, Hessel EA, Slichter S. Mechanism of abnomal bleeding in patients undergoing cardiopulmonary bypass: acquired transient platelet dysfunction associated with selective alpha-granule release. Blood $1980,56: 824-834$

Hawkins SS, Aveling W. Treasure T, Forsling M. Hypertension, vasopressin and renim in coronary artery surgery. Br J Anaesth 1983;55:1161P

Hawkins SS,Forsling M, Treasure T. Aveling W. Changes in pressor hormone concentrations in association with coronary artery surgery. Br J Anaesth $1986,58: 1267 \cdots 1272$

Head GA, Korner Pl. Cardiovascular functions of brain serotonergic neurons in the rabbit as analyzed from the acute and chronic effects of 5,6-ditydroxytryptamine. J Cardiovasc Pharmacol 1982;4:398-408

Hechtman HB, Sherpo. D. Platelet serotonin (5HT) and control of the pulmonary micracirculation. Int J Microcirc, Clinical and Exp 1984;3:467-471

Hedner T. Persson B. Berglund G. A comparitive and long.term evaluation of ketanserin in the treatment of essentiall hypertension. J Cardiovasc Pharmacol 1985; 7(suppl 7):148-153

Heidenstierna $G_{\text {, }}$ Tokics L. Strandberg A, Lundquist H, Brismar B. Correlation of gas exchange impairment to development of atelectasis during anaesthesia and muscle paralysis. Acta Anaestesiol Scand 1986;30:183-191

Heiden D. Mielke $\operatorname{Jr} \mathrm{CH}$, Rodvien R. Impairment by heparin of primary haemastasis and platelets (14C)5-hydroxytryptamine rellease. $\mathrm{Br} \&$ Haematol 1977,36:427-431

Heikkila $H_{*}$ Jalonen $J_{*}$ Arola $M$, Laaksonen V. Haemodynamics and myocardial oxygenation during anaesthesia for coronary artery surgery: comparison between enflurane and high-dose fentanyl anaesthesia. Acta Anaesthesiol Scand $1985,29: 457-464$

Heinonen J, Salmenpera $M_{*}$ Takkunen 0 . increased pulmonary artery diastolic-puimonary wedge pressure gradient after cardiopulmonary bypass. Can Anaesth Sac J 1985;32:165-170

Hempelman $G$, Dieter $K$, Volker $L$, van Borman $B$. Cerebral protection in neurosurgery, cardiac surgery, and following cardiac arrest. J Cereb Blood Flow Mettabol 1982;2 (suppil 1):66-71

Heneghan $\mathrm{CPH}$, Bergman $\mathrm{NA}_{4}$ Jones JG. Changes in lung volume and $\left(\mathrm{PAO}_{2}-\mathrm{PaO}_{2}\right)$ during anaesthesia. $\mathrm{Br} J$ Anaesth 1984,56:4.37-4.45

Henry PD, Schuchlieb R, Clark RE, Perez JE. Protection of ischemic myocardium by nifedipine. In: The Fourth International Adalat Symposium, ed Puech P. Krebs R.

Amsterdam: Excerpta Medica, 1980, pp 189-196 
Hess W. Amold B, Schulte-Sasse U. Tarnow J. Comparisan of isoflurane and halothane when used to control intraoperative hypertension in patients undergoing colonary artery bypass surgery. Anaesth Analg 1983,62:15-20

Hess W. Meyer C. Haemodynamic effects of nifedipine in patients undergoing coronary artery bypass surgery. Acta Anaesthesiol Scand 1986;30.614-619

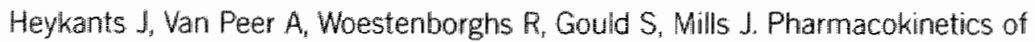
ketanserin and its metabolite ketanserin-ol in man after intravenous, intramuscular and oral administration. Eur J Clin Pharmacol 1986;31:343-350

Hickey RF, Verrier ED, Baer RW, Wahakes GJ, Fein G. Hoffman JIE. A canine model of acute coronary artery stenosis: effects of deliberate hypotension. Anesthesiology $1983 ; 59: 226-236$

Hilberman $M$ Myers BD, Carrie BJ, Derby $G$, Jamison RL, Stinson $E B$. Acute renal failure following cardiac surgery, J Cardiovasc Surg 1979;77:880-888

Hinds CJ. Current management of patients after cardiopulmonary bypass. Anaesthesia 1982;37:170-191

Hine IP, Wood WG, Mainwaring-Burton RW, Butler MJ, Irving MH, Booker B. The adrenergic response to surgery involving cardiopulmonary bypass, as measured by plasma and urinary catecholamine concentrations. Br J Anaesth 1976;48:355-363

Hoar PF. Hickey RF, Ullyot DJ. Systemic hypertension following myocardial revascularisation. A method of treatment using epidural anesthesia. \& Thorac Cardiovasc Surg 1976;71:859-864

Hoffmann BB, Lefkowitz RJ. Alphamadrenergic receptor subtypes. N Eng J Med $1980 ; 302: 1390-1396$

Hoffman JIE, Buckberg GD. The myocardial oxygen supply:demand ratio. A critical review. Am J Carcliol 1978,41:327-332

Hosie $\rrbracket_{\text {, Stott }}$ D., Robertson JIS Ball SG. Does acute serotonergic type-2 antagonism reduce biood pressure? Comparitive effects of single doses of ritanserin and ketanserin in essential hypertension. J Cardiovasc Pharmacol (in press)

Houghton $K_{n}$ Carter JA. Peri-operative management of carcinoid syndrome using ketanserin. Anesthesia 1986;41:596-599

Houston DS, Shepherd JT, Vanhoutte PM. Platelets cause endothelium-dependent relaxations in some but not in all isolated canime vessels. Physiologist (in press)

Howie $M B_{0}$ Varma $A$, Sparks J, Reilley $T$, Cook R. The relationship of plasma fentanyl levels to the postoperalive course of open heart surgery patients. Anesthesiology $1981 ; 55: A 45$ 
Howie MB, MCSweeney TD, Lingam RP, Maschke SP. A comparison of fentanyl-O, and sufentanil- $\mathrm{O}_{2}$ for cardiac anesthesia. Anesth Analg 1985,64:877-887

Hsu HO, Hickley RF, Forbes AR. Morphine decreases peripheral vascular resistance and increases capacitance in man. Anesthesiology 1979,50:98-102

Huval WV, Mathieson MA, Stemp LI, Dunham BM, Jones AG, Shepro D, Hechtman HB. Therapeutic benefits of 5-hydroxytryptamine inhibition following pulmonary embolism. Ann. Surg. 1983; 197:220-225

Huval WV, Lelcuk S, Shepro D, Hechtman HB. Role of serotonin in patients with acute respiratory failure. Ann Surg 1984;200:166-172

Ilicin G, Saylam A, Bozer AY. The effect of extracorporeal circulation on serotonin metabolism. Ann Thorac Surg 1972;13:225-228

Insel J, Weissman C, Kemper M, Askanazi J, Hyman Al. Cardiovascular changes during transport of critically ill and postoperative patients. Crit Care Med 1986;14:539.542

Ivanov J, Seawright SJ, Madonik MM, Mickle DAG, Scully HE, Goldman BS, Mclaughlin PR. Effects of postoperative hypertension and its treatment. J Thorac Cardiovasc Surg 1983;86:47-56

Ivanov J. Aweisel RD, Mickleborough LL, Hilton JD, McLaughtin PR. Rewarming hypovolemia after aortocoronary bypass surgery. Crit Care Med 1984;12:1049-1054

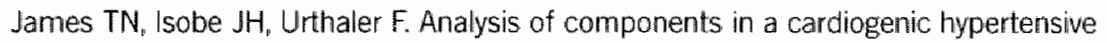
chemoreflex. Circulation 1975;52:840-845

Janssen PAJ. Pharmacology of potent and selective $\mathrm{S}_{2}$-serotonergic antagonists. J Cardiovasc Pharmacol 1985;7 (supp| 7): 2-11

Jardin F, Farcot J-C, Boisante L, Curien N, Margairaz A, Bourdarias J-P. Influence of positive end-exspiratory pressure on left ventricular performance. N Eng J Med $1981 ; 304: 387-392$

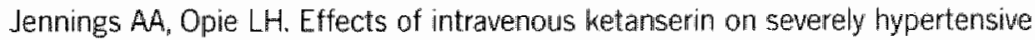
patients with double-blinded cross-over assessment of central side-effects. J Cardiovasc Pharmacol 1987;9:120-124

Jones HM, Matthews N, Vaughan RS, Stark JM. Cardiopulmonary bypass and complement activation. Anesthesia 1982;37:629-633

Jones DK, Higenbottam TW, Wheeldon D, Kneeshaw J, Bethune D, Wallwork J. Prostacyclin, cardiopulmonary bypass and the alveolar capillary membrane. Perfusion 1986;1:165-173 
Jonmarker $C$. Nordstrom $L$, Werner $O$. Changes in functional residual capacity during cardiac surgery. Br J Anaesth 1986;58:428-432

Kalkman HO, Timmermans PB, Zwieten van PA. Characterization of the antihypertensive properties of ketanserin (R41468) in rats. J Pharmac Exp Ther $1982,222,227-231$

Kaplan JA, Finlayson DC, Woodward S. Vasodilator therapy after cardiac surgery: a review of the efficacy and toxicity of niltroglycerin and nitroprusside. Can Anaesth Soc J $1980 ; 27: 254-259$

Kaplan JA, Jones EL. Vasodilator therapy during coronary artery surgery Comparison of nitroglycerin and nitroprusside. J Thorac Cardiovasc Surg 1979;77.301-309

Kassel NF, Boarini DJ, Olin JJ, Sprowell JA. Cerebral and systemic circulatory effects of arterial hypotension induced by adenosine. J Neurosurg 1983;58:69-76

Kaufman $L$. Use of labetolol during hypotensive anaesthesia and in the management of phaeochromocytoma. Br J Clin Pharmacol 1979;suppl 8:229

Kaiul TK, Bain WH, Jones IV, Lorimer AR, Thompson RM, Turner MA, Escarous A. Mitral valve replacement in the presence of severe pulmonary lnypertension. Thorax $1976 ; 31: 332-337$

Kaumann AJ. Yohimbine and rauwolscine inhibit 5-hydroxytryptamine-induced contraction of large coronary arteries of calf through blockadie of $5-\mathrm{HT}_{2}$, receptors. Arch Pharmacol 1983;323:149-154

Kay B, Healy TEJ, Bolder PM. Blocking the circulatory responses to tracheal intubation. A comparison of fentanyl and nalbuphine. Anaesthesia 1985:40:960-963

Kien ND, Reitan JA, White DA, Wu $\mathrm{CH}_{n}$ Eisele Jr JH. Hemodynamics responses to alfentanil in halothane-anesthetized dogs. Anesth Analg 1986;65:765-70

Kin YD, Jones $M$, Hanowell ST, Koch JP, Lees DE, Weise $V$, Kopin IJ. Changes in peripheral vascular and cardiac sympathetic activity before and after coronary artery bypass surgery: Interrelationships with hemodynamic alterations. Am Heart J. $1981 ; 102: 972-979$

Kirk ES, Le Jemtel TH, Nelson GR. Mechanisms of beneficial effects of vasodilators and inotropic stimulation in the experimental failing ischemic heart. A.m J Med $1978 ; 65: 189-196$

Kirklin JW, Conti VR, Blackstone EH. Prevention of myocardial damage during cardiac operations. N Eng J Med 1979;301:135-141 
Kirklin JK, Chenoweth DE, Naftel DC, Blackstone EH, Kirklin JW, Bitran DD, Curd JG, Reves JG, Samuelson PN. Effects of protamine administration after cardiopulmonary bypass on complement, blood elements, and the hemodynamic state. Ann Thorac Surg 1986:41:193-199

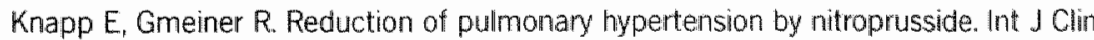
Pharmacol 1977:15:75

Knight A, Forsling $M_{0}$, Treasure $T$, Aveling $W$, Loh L, Sturridge MF. Changes in plasma vasopressin concentration in association with coronary artery surgery or thymectomy. Br J Anaesth 1986;58:1273-1277

Knight PR, Lane GA, Hensinger RN, Bolles RS, Bjoraker DG. Catecholamine and renin-angiotensin response during hypotensive anesthesia induced by sodium nitroprusside or trimethaphan camsylate. Anesthesiology 1983;59:248-253

Kobinia GS, LaRaia PJ, DAmbra MN, Fabri BM, Aylesworth CA, Peterson MB, Watkins WD, Buckley MJ. Effect of experimental cardiopulmonary bypass on systemic and transcardiac thromboxane $B_{2}$ levels. J Thorac Cardiovasc Surg 1986;91:852-857

Kach-Weser J. Hydralazin. N Eng J Med 1976:295:320-323

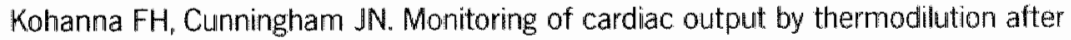
open-heart surgery. J Thorac Cardiovaisc Surg 1977,73:451-457

Kolkka R, Hilberman M. Neurologic dysfunction following cardiac operation with low-flow, low-pressure cardiopulmonary bypass. I Thorac Cardiowasc Surg $1980 ; 79: 432-437$

Kopman EA, Weygandt GR, Baver S, Fergurson TB. Arterial hypokemia following the administration of sublingual nitroglycerin. Am Heart J 1978;96:443-447

Kopman EA. Relief of pulmonary congestion by sublingual nitroglycerin in patients with mitral valve disease. Anesth Analg 1979;58:143-144

Koyama S, Kiyono S, Kayaba K, Kimura M, Nishizawa M. Cardiovascular and blood gas responses to ketanserin in canine pulmonary edema induced by oleic acid. Anesthesiology 1985;62:457-461

Kuhn DM, Wolf WA, Lowenberg W. Review of the role of the centrall serotonergic neuronal system in blood pressure regulation. Hypertension 1980;2:243-255

Laduron PM, Janssen PFM, Leysen JE. In vivo binding of ( $\left.{ }^{3} \mathrm{H}\right)$ ketanserin on serotonin $\mathrm{S}_{2}$ receptors in rat brain. Eur J Pharmacoll 1982;81:43-49

Lagerkranser M, Sallevi A, Irestedt L, Tidgren B, Andreen M. Renin release during controlied hypotension with sodium nitroprusside, nitroglycerin and aclenosine: a comprarative study in the dog. Acta Anaesth Scand 1985;29:45-49 
Lagerkranser $M$, Irestedt $L$, Sollevi A, Andreen M. Central and splanchnic hemodymamics in the dog during controlled hypotension with adenosine. Anesthesiology $1984,60.547-552$

Lakoski JM, Aghajanian GK. Effects of ketanserin on rieuronal responses to serotonin in the prefrontal cortex, lateral geniculate and dorsal raphe nucleus. Neuropharmacol $1985 ; 24: 265 \cdot 273$

Landymare RW, Murphy DA, Kinley CE, Parrott JC, Moffitt EA, Longley WJ, Quibic AA. Does pulsatile flow influence the incidence of postoperative inpertension. Ann Thorac Surg 1979:28:261-265

Lappas D. Powel WMI, Daggett WM. Cardiac dysfunction in the perioperative periad. Pathophysiology, diagnosis, treatment Anesthesiology 1977:47:117-127

Laver MB, Hallowell P. Goldblatt A. Pulmonary dysfunction secondary to heart disease: Aspects relevant to anesthesia and surgery. Anesthesiology 1970;33:161-192

Lehmann KA, Heimig Th. Circulatory response to urapidil (Ebrantil) during general and regional anaesthesia. A study with normo- and hypertensive patients. Anaesthesist $1985 ; 34: 435-445$

Leysen JE, Awouters. F, Kenis L, Laduron PM, Vandenberg J, Janssen PAJ. Receptor binding profile of $\mathrm{R} 41468$, a novel antagonist at $5-\mathrm{HT}$, receptors. Life Sci

1981:28:1015-1022

Leysen JE, Niemegeers CJE, Van Nueten JM, Laduron PM. ${ }^{3} H$ Ketanserin (R41468), a selective ${ }^{3} \mathrm{H}-l$ ligand for serotonin, receptor binding sites. Binding properties, brain distribution, and functional role. Mol Pharmacol 1982:21:301-314

Leysen J. Serotonin receptor binding sites: is there pharmacological and clinical significance. Med Biol 1983;61:139-143

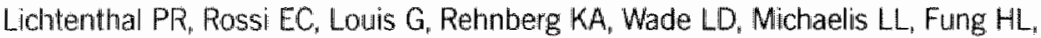
Patrignani $P$. Dose-related prolongation of the bleeding time by intravenous. nitroglycerin. Anesth Analg 1985;64:30-33

Loeb HS, Khan M, Klodnycky ML. Hemodynamic effects of dobutamine in man. Circ Shock $1975,2: 29-35$

Low JM, Harvey JT, Prys-Roberts C, Dagnino J. Studies of anaesthesia in relation to hypertension. Br J Anaesth 1986:58:471-477

Lowry KG, Dundee IW, McClean E, Lyons SM, Carson IW, Orr IA. Pharmacokinetics of diazepam and midazolam when used for sedation following cardiopulmonary bypass. $\mathrm{Br} 」$ Anaesth 1985;57:883-885 
Lumley P, Broadley KJ, Levy GP. Analysis of the inatropic: chronotropic selectivity of dobutamine and dopamine in anaesthetised dogs and guinea-pig isolated atria.

Cardiovasc Res 1977;11:17-25

Lynch JP, Mhyre JG, Dantzker DR. Influence of cardiac output on intrapulmonary shunt. J Appl Physial 1979;46:315-320

Maggi CA, Manzini S, Meli A. Contribution of cellular and extracellutar $\mathrm{Ca}^{2 *}$ during 5-hydroxytryptamine induced contractions of rabbit ear artery. Eur J Pharmacol $1983 ; 94: 251-260$

Majid PA, De Jong J. Acute hemodynamic effetcs of nifedipine in patients with ischemic heart disease. Circulation 1982,65:1114-1118

Marshall BE, Wyche MQ. Hypoxemia during and after anesthesia. Anesthesiology 1972;37:178-209

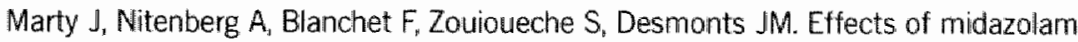
on the coronary circulation in patients with coronary artery disease. Anesthesiology $1986 a ; 64: 206-210$

Marty $J_{0}$ Gauzit $R$, Lefevre P, Couderc E, Farinotti R, Henzel C, Desmonts JM. Effects of diazepam and midazolam on baroreflex control of heart rate and on sympathetic activity in humans. Anesth Analg 1986b;65:113-119

Marvel SL, Elliott CG, Tocino I, Greenway LW, Metcalf SM, Chapman RH. Positive end-expiratory pressure following coronary artery bypass grafting. Chest $1986 ; 90: 537 \cdot 541$

McCall RB, Schuette MR. Evidence for an alpha-1 receptor-mediated central sympathoinhibitory action of ketanserin. J Pharmcol Exp Ther 1984:228:704-710

McCollum JSC, Dundee JW. Comparison of induction characteristics of four intravenous anaesthetic agents. Anaesthesia 1986;41:995-1000

McGourty JC, Silas $\mathrm{JH}$, Cowen KJ. Efficacy of ketanserin in hypertension. Clin Sci $1984 ; 67: 47$

Mcllduff JB, Daggett WM, Buckley MJ, Lappas DG. Systemic and pulmonary hemodynamic changes immediately following mitral valve replacement in man. J Cardiovasc Surg 1980;21:261-266

Mckenna R, Bachmann F, Whittaker B, Gilson JR, Weinberg Jr M. The hemostatic mechanism after open-heart surgery. II. Frequency of abnormal platelet functions during and after extracorporeal circulation. I Thorac Cardiovasc Surg $1975 ; 70: 298-308$ 
Melot $\mathrm{C}$. Naeje $\mathrm{R}$, Mols $\mathrm{P}$, Vandenbossche $\mathrm{J}$, Denolin $\mathrm{H}_{\text {. Effects }}$ ef nifedipine on wentilation/perfusion matching in primary pulmonary hypertension. Chest $1983,83203-207$

Merin RG. Is anesthesia beneficial for the ischemic heart? Anesthesiology $1986,65.539-542$

Metha MP, Dillman JB, Sherman BM, Ghoneim MM, Lemke JH. Etomidate anesthesia inhilitits the cortisol response to surgical stress. Acta Anaesthesiol Scand $1985 ; 29: 486-489$

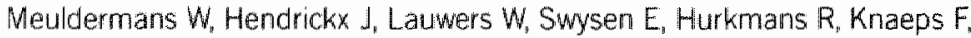
Woestenborghs R. Heykants $J$. Excretion and biotransformation of ketanserin after oral and intravenous administration in rats and dogs. Drug Metab Dispos

$1984 ; 12: 772-781$

Meuleman TR, Hill DC, Port JD, Stanley TH, Pace NL, Mohammad SF, Ketanserin prevents platelet aggregation and endotoxin-induced pulmonary vasoconstriction. Crit Care Med 1983;11:606-611

Miller RD. Pharmacokinetics of competitive muscle relaxants. Br J Anaesth $1982 ; 54: 161 \cdot 167$

Milocco 1, Lof BA, William-OIsson G, Appelgren LK. Haemodynamic stability during anaesthesia induction and sternotomy in patients with ischaemic heart disease. Acta Anaesthesiol Scand 1985;29:465-473

Miranda DR, Stoutenbeek C, Karliczek G, Rating W. Effects of dexamethason on the early postoperative course after coronary artery bypass surgery. Thorac Cardiavasc Surgeon 1982;30:21-27

Moffitt EA. Anaesthetic managernent for coronary artery bypass surgery. Can Anaesth Soc J 1978,25:462-467

Moffitt EA, Sethna DH. The coronary circulation and myocardial oxygenation in coronary artery disease: effects of anesthesia. Anesth Analg 1986;65:395-410

Molfitt EA, Sethna DH, Bussell JA, Raymond JA, Matloff RMJ, Gray RJ. Effects of intubation on coronary blood flow and imyocardial oxygenation. Can Anaesth Sac $\downarrow$ 1985;32:105-111

Moffitt EA, Scovil JE, Barker RA, Marble AE, Sullivan JA, Delcampo C, Cousins CL, Kinley $E$. Myocardial metabolism and haemodynamic responses during high-dose fentanyl anaesthesia for coronary patients. Can Anaesth Soc J 1984;31:611-618

Moffitt EA, Sethna DH, Gray RJ, Raymond MJ, Bussell JA, Matloff JM. Myocardial and systemic effects of nitroglycerin, given awake and during anaesthesia in coronary patients. Can Anaesth Soc J 1983;30:352-359 
Mohr R, Golan M, Martinowitz U, Rosner E, Goor DA, Ramot B. Effect of cardiac operation on platelets. J Thorac Cardiovasc Surg 1986;92:434-441

Molloy DW, Ducas J, Dabson K, Girling L, Prewitt RM. Hemodynamic management in clinical acute hypoxemic respiratony failure: dopamine vs dobutamine. Chest $1986 ; 89 ; 636-640$

Moore RA, Allen MC, Wood PJ, Rees LH, Sear JW. Peri-operative endocrine effects of etomidate, Anaesthesia 1985a:40:124-130

Moore RA, Geller EA, Gallagher JD, Clark DL. Effect of hypothermic cardiopumonary bypass on nitroprusside metabolism. Clin Pharmacol Ther 1985b;37:680-683

Moses JW, Wertheimer JH, Bodenheimer MM, Banka WS, Feldman M, Helfant RH. Efficacy of nifedipine in rest angina refractory to propanolol and nitrates in patients with obstructive coronary artery disease. Ann Int Med 1981;94:425-429

Morel DR, Forster A, Suter PM. I.w. labetolol in the treatment of hypertension following coronary artery surgery. $\mathrm{Br} J$ Anaesth 1982;54:1191-1196

Mostbeck A, Partsch H, Peschel L. Investigations on peripheral blood distribution. In: Illrd international Adalat Symposium, eds. Jatene AD, Lichtlen PR. Amsterdam; Excerpta Medica,1976, pp $91-97$

Mullane KM, Bradley G, Moncada S. The interactions of platelet-derived mediators on isolated canine coronary arteries. Eur J Pharmacol 1982;84:115 118

Murkin JM, Moldenhauer CC, Hug CC. High-dose fentanyl for rapid induction of anaesthesia in patients with coronary artery disease. Can Anaesth Soc J $1985 ; 32: 320-325$

Murphy MR, Hug CC, McClain DA. Dose-independent pharmacokinetics af fentanyl. Anesthesiology 1983,59:537-540

Murphy BF, Whitworth JA, Kincaid-Smith P. Ketanserin in the acute management of severe hypertension. $J$ Cardiovasc Pharmac 1985; 7(suppl 7):168-171

Mylecharane EJ, Phillips CA, Markus JK, Shaw J. Evidence for a central component to the hypotensive action of ketanserin in the dog. J Cardiovasc Pharmac 1985; 7 (suppl 7):114-116

Nalda MA, Gomar C, Luis M. The effect of ketanserin on post-anaesthetic vasoconstriction and shivering. Eur J Anaesth 1985,2265-277

Nelson MA, Coghlan JP, Denton DA, Mills EH, Spence CD, Whitworth JA, Scoggins BA. Demonstration of alpha-adrenoceptor antagonism by the $5 \mathrm{HT}_{2}$ antagonist ketanserin in sheep. Clin Exp Pharmacol Physiol 1984;11:597-604 
Newberg Midde $\mathrm{L}_{i}$ Milde JH. Preservation of cerebral metabolites by etomidate during incomplete cerebral ischemia in dogs. Anesthesiology 1986;65:272-277

Newsome LR, Roth JV, Hug CC, Nagle D. Esmolol attenuates hemodynamic responses during fentamylpancuronium anesthesia for aortocoronary bypass surgery. Anesth Analg 1986,65:451-456

Niarchos AP. Evaluation of intravenous clonidine for hypertensive emergencies. $J$ Clin Pharmacol 1978:18:220-228

Nimmo WS, Miller M. Pharmacology of etomidate. New Pharmacologic Vistas in Anesthesia $1983 ; 7,83-95$

Nussmeier NA, Arlund C, Slogoff S. Neuropsychiatric complications after cardiopulmonary bypass: cerebral protection by a barbiturate. Anesthesiology $1986 ; 64: 165-170$

O'Connor DE. Accelerated acute clonidine withdrawal syndrome during coronary artery bypass surgery, a case report. Br J Anaesth 1981;53:431-433

Oxdemir IA, Kusajima K, Wax SD, Webb W. Effects of serotonin on pulmonary vascular resistance and microcirculation. Circulation 1972;46(suppl 11):56

Packer M. Vasodilator therapy for primary pulmonary hypertension. Ann Int Med $1985 ; 103: 258-270$

Page $\| \mathrm{H}, \mathrm{McCubbin} \mathrm{JW}$. The wariable arterial pressure response to serotonin in laboratory animals and man. Circ Res 1953;1:354-362

Parsons GH, Leventhal JP, Hansen MM, Goldstein JD. Effect of sodium nitroprusside on hypoxic pulmonary vasoconstriction in the dog. J Appl Physiol 1981;51:288-292

Patel CB, Laboy V, Venus B, Mathru M, Wier D. Use of sodium nitroprusside in post-coronary bypass surgery: a plea for conservatism. Chest 1986;89:663-667

Pauca $\mathrm{AL}_{\mathrm{i}}$ Roy $\mathrm{RC}$. Hypertensive response to thiopental in man during cardiopulmonary bypass. Acta Anaesthesiol Scand 1986;30:562-565

Persson $B$, Hedner T, Henning M. Cardiovascular effects in the rat of ketanserin, a novel 5-hydroxytryptamine receptor blocking agent. J Pharm Pharmacol $1982 ; 34: 442-445$

Peters RM, Brimm JE, LIlley JR. Predicting the need for prolonged ventilatory support in adult cardiac patients. J Thorac Cardiovasc Surg 1979;77:175-182

Pettersson A, Persson B, Henning M, Hedner T. Antihypertensive effects of chronic 5-hydroxytryptamine $\left(5-\mathrm{HT}_{2}\right)$ receptor blockade with ketanserin in the spontaneously hypertensive rat. Naunym-Schmiedeberg's Arch Pharmacol 1984;327:43-47 
Pettersson A, Gradin K, Hedner T, Persson B. Antihypertensive mechanism of action of ketanserin and some ketanserin analogues in the spontaneously hypertensive rat. Naudyn Schmiedeberg's Arch Pharmacol 1985b-329:394-397


1975;293:1179-1180

Phillips CA, Mylecharane EJ, Markus JK, Shaw J. Hypotensive actions of ketanserin in dogs: involvement of a centrally mediated inhibition of sympathetic vascular tone. Eur J Pharmacol 1985;111:319-327

Pletscher A, Affolter $\mathrm{H}$. The 5-hydroxytryptamine receptor of blood platelets. J Neural Transmission 1983;57:233-242

Pluth JR, Ellis RH. Tricuspid insufficiency in patients undergoing mitral valve replacement: Conservative management, anmuloplasty, or replacement. J Thorac Cardiovasc Surg 1969;58:484-491.

Puchstein $C$, Van Aken $H$, Zander J, Lawin P. The use of urapidil in the postoperative phase. Anaesthesist 1984;33:224-227

Radegran $\mathrm{K}$, Eberg $N$, Papaconstantinou $\mathrm{C}$. Effects of prostacyclin during cardiopulmonary bypass in man. Scand J Thor Cardiovasc Surg 1981;15:263-268

Radnay PA, Rao DVS, Yun $\mathrm{H}$. Hemodynamic changes during induction of neurolept anesthesia for aortocoronary bypass surgery. Anesthesiol Rev 1977,4:13-16

Rapport MM, Green AA, Page $1 \mathrm{H}$. Serum vasoconstrictor (serotonin). Isolation and characterization. J Biol Chem 1948;176:1243

Rehder K, Sessler AD, Marsh HM. General anesthesila and the lung. Am Rew Resp Dis $1975 ; 112: 541-563$

Reid LM. Structure and function in pulmonary hypertension: new perceptions. Chest 1986,89:279-287

Reimann IW, Frolich JC. Mechanism of antihypertensive actiom of ketanserin in man. Brit Med J 1983a;287:381-383

Reimann IW, Okonkwo PO, Klotz U. Pharmacokinetics of ketanserin in mam. Eur $\mathbb{J}$ Clin Pharmacol 1983b;25:73-76

Reimann IW, Ratge D, Wisser H, Klotz U. Effect of intravenous ketanserin on plasma catecholamines and renin activity in normal volunteers. Eur \Clin Pharmacol $1985 ; 28: 273-277$ 
Reimers HJ, Packman MA, Kinlough-Rathbone RZ, Mustard JF. Effects of repeated treatment of rabbit platelets with low concentrations of thrombin on their function. metabolism and survival. Br J Haematol 1973, 25.675-689

Reiz S, Ostman M Regional coronary hemodynamics during isoflurane-nitrous oxide anesthesia in patients with ischemic heart disease. Anesth Analg 1985;64:570-576

Reneman RS, Jagenau AHM, Xhonneux R, Laduron P. The cardiovascular pharmacology of etomidate, a new, potent and shortwacting intravenous hypnotic agent. In: Recent Progress in Anesthesiology and Resuscitation. Excerpta Medica, Amsterdam, 1974; pp 152-156

Replogle R, Lewy M, deWall RA, Lillehei RC. Catecholamine and serotonin response to cardiopulmonary bypass. J Thorac Cardiovasc Surg 1962;44:638-648

Reves JG, Karp RB, Buttrer EE, Tosone S, Smith LR, Samuelson PN, Kreusch GR, Oparil S. Neuronal and adrenomedullary catecholamine release in response to cardliopulmonary bypass in man. Circulation 1982;66:49-55

Reves $J G$, Fragen RJ, Vinik HR, Greenblatt DJ. Midazolam; pharmacolagy and uses. Anesthesiology 1985;62:310-324

Richards DA. Pharmacological effects of liabetolol in man. Br J Clin Pharmacol 1976; (suppl)3:721-723

Roberts AJ, Niarchos AP, Subramanian VA, Abel RM, Herman SD, Sealey JE, Case DB, White RP, Johnson GA, Laragh JH, Gay WA. Systemic hypertension associated with coronary artery bypass surgery. Predisposing factors, hemodynamic characteristics. humoral profile, and treatment. J Thorac Cardiovasc Surg 1977;74:846-859

Robicsek F. Acute methemoglobinemia during cardiopulmonary bypass caused by intravenous nitroglycerin infusion. J Thorac Cardiovasc Surg 1985;90:931-934

Robinson SE. Interaction of the median raphe nucleus and hypothalamic serotonin with cholinergic agents and pressor responses in the rat. J Pharmacol Exp Ther $1982 ; 223: 662-668$

Rosenthal MH, Pearl RG, Schroeder JS, Ashton JPA. Nitroglycerin versus nitroprusside in pulmonary hypertension. Anesthesiology 1981:55:A79

Rosoff CB, Salzman EW, Gurewich A. Reduction of platelet serotonin and the response to puimonary emboli. Surgery 1971;70:12-19

Rosow CE, Philbin DM, Keegan CR, Moss J. Hemodynamics and histamine release during induction with sufentanil or fentanyl. Anesthesiology 1984;60:489-491

Rounds S, Hill NS. Pulmonary hypertensive diseases. Chest 1984;85:397-405 


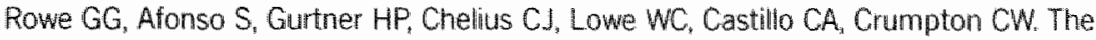
systemic and coronary hemodynamic effects of adenosine triphosphate and adenosine. Am Heart J 1962;64:228-234

Rucquoi M. Claeys MA, Schneider $I_{\text {}}$ Camu F. Effects of ketanserin on haemodynannic performance during postoperative hypertension. Acta Anaesth Belg 1985:2:84

Saarnivaara L, Brander P. Comparison of three hypotensive anaesthetic methods for middle ear microsurgery. Acta Anaesthesiol Scand 1984;28:435-442

Sade RM, Stroud MR, Crawford FA, Kratz JM, Dearing JP, Bartles DM. A prospective randomized study of hydroxyethyl starch, albumin, and lactated Ringer's solution as priming fluid for cardiopulmonary bypass. I Thorac Cardiovase Surg $1985 ; 89: 713-722$

Salerno TA, Henderson M, Keith FM, Charrette EJP. Hypertension after coronary operation. Can it be prevented by pulsatile perfusion? J Thorac Cardiovasc Surg $1981 ; 81: 396-399$

Salmenpera $\mathrm{M}_{4}$ Heinonen J. Pulmonary vascular responses to moderate changes in $\mathrm{PaCO}_{2}$ after cardiopulmonary bypass. Anesthesiology 1986;64:311-315

Salomon NW. Plachetka JR, Copeland JG. Comparison of dopamine and dobutamine following coronary artery bypass grafting. Ann Thorac Surg 1982;33:48-54

Saman S, Thandroyen F, Opie LH. Serotonin and the heart: effects of ketanserin on myocardial function, heart rate, and arrythmias. J Cardiovasc Pharmacol 1985;7(suppl 7):\$70-\$75

Sandoval J, Lopez R, Beltran U, Gomez A, Martinez W, Vazquez V. Figueroa J, Seoane $M$, Lupi-Herrera E. Effect of hydralazine on intrapulmonary shunt. Crit Care Med $1986 ; 14: 689-692$

Sanford TJ, Ty Smith N, Dec-Silver H, Harrison WK. A comparison of morphine, fentanyl, and sufentanil anesthesia for cardiac surgery: induction, emergence, and extubation. Anesth Analg 1986;65:259 66

Sarajas HSS, Kristoffersson $\mathrm{R}_{\mathrm{F}}$ Frick $\mathrm{MH}$. Release of adenosine triphosphate and serotonin from injured cellular blood elements in extracorporeal circuits. Nature $1959 ; 184: 1127-1129$

Saxena PR, Bonta IL. Mechanism of selective cardiac vagolytic action of pancuronium bromide Specific blockade of cardiac muscarinic receptors. Eur J Pharmacol $1970 ; 11: 332-341$

Schmid-Schonbein H. In; Discussion, basic aspects of blood trauma.

H Schmid-Schonbein, P Teitel, eds. Martinus Nijhoff Publ, The Hague, 1979,99 
Scroop GC, Walsh JA. Interactions between angiotensin, moradrenalin and serotonin on the peripherall blood vessels in man. Aust J Exp Biol Med Sci 1968:46:573-580

Sear JW. Toxicity of iv anaesthetics. Br J Anaesth 1987,59:24-45

Sebel PS, Bowill JG, Boekhorst RAA, Rog N. Cardiovascular effects of high-dose fentanyl anaesthesia. Acta Anaesth Scand 1982;26:308-315

Seltzer JL, Doto JB, Jacoby J. Decreased arterial oxygenation during sodium nitroprusside administration for intraoperative hypertension. Anesth Analg $1976,55: 880-881$

Shell WE, Sobel BE. Protection of jeopardized ischaemic myocardium by reduction of ventricular afterload. N Eng J Med 1974;291:481-486

Shoernaker WC, Appel PL, Kram HB. Hemodynamic and oxygen transport effects of dobutamine in critically ill general surgical patients. Crit Care Med $1986 ; 14: 1032-1037$

Sibbald WJ, Driedger AA, Cunningham DG, Cheung H. Right and left ventricular performance in acute hypoxemic respiratory failure. Crit Care Med 1986; 14:852-857

Sill JC, Nugent M, Moyer TP, Torres LE, Schaff HV, Tinker JH. Influence of propranolol plasma levels on hemodynamics during coronary artery bypass surgery.

Anesthesiology 1984,60:455-463

Sivah ED, Starr N』, Grave JW, Cosgrove DM, Borsh J, Estafanous G. Extra-vascular lung water values in patients undergoing coronary artery bypass surgery. Crit Care Med 1982;10:593-596

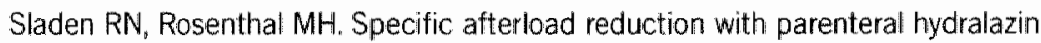
following cardiac surgery. I Thorac Cardiovasc Surg 1979;78:195-199

Slogoff S, Keats AS, Ott E. Preoperative propanolol therapy and aortocoronary bypass operation. JAMA 1978;240:1487-1490

Slogoff $S_{\text {" Girgis }} \mathrm{KZ}$, Keats AS. Etiologic factors in neuropsychiatric complications associated with cardiopulmonary bypass. Anaesth Analg 1982;61:903-911

Slogoff $S$, Keats AS. Further observations on perioperatiwe myocardial ischemia. Anesthesiology $1986,65: 539 \times 542$

Slogoff $S_{4}$ Keats A. Does perioperative myocardial ischemia lead to postoperative myocardial infarction? Anesthesiology $1985 ; 62 ; 107-114$

Smits JFM, Struyker-Boudier HAJ. Intrahypothalamic serotonin and cardiovascular control in rats. Brain Res 1976"11:422-427 
Smits JFM, wan Essen $H$, Tijssen CM, Struyker-Boudier HAJ. Effects of ketanserin on hemodynamics and baroreflex effects in conscious spontaneously hypertensive rats. Cardiovasc Pharmacol 1987;10:1-8

Sniderman A, Burdon T, Homan J, Salerno TA. Pulmonary blood flow; a potential factor in the pathogenesis of pulmonary edema. J Thorac Cardiovasc Surg $1984: 87: 130-135$

Solis RT, Beall Jr AC, Noon GP; De Bakey ME. Platelet aggregation: effects of cardiopulmonary bypass. Chest 1975b;67:558-564.

Sollevi $A_{*}$ Lagerkranser $M$, trestedt $L$, Gordon $E$, Lindquist $C$. Controlled hypotension with adenosine in cerebral aneurysm surgery. Anesthesiology 1984;61:400-405

Sonneblick EH, Frisham WH, Le Jemtel TH. Dobutamine: a new synthetic cardioactive sympathetic amine. N Eng J Med 1979;300:17-22

Sorensen O, Waaben I, Andersen KB, Skowsted P. The incidence of cardiac arrhythmias and arterial hypotension subsequent to standardized surgical stimuli in patients undergoing thoracotomy. With reference to enflurane and halothane. Acta Anaesthesiol Scand 1986;30:630-632

Sotaniemi KA. Brain damage and neurological outcome after open-heart surgery. J Neurol Neurosurg Psych 1980;43:127-135

Spiss CK, Coraim F, Haider W, White PF. Haemodynamic effects of fentanyl or alfentanil as adjuvants to etomidate for induction of anaesthesia in cardiac patients. Acta Anaesthesiol Scand 1984;28:554-556

Stein $M_{1}$ Thomas DP. Role of platelets in the acute pulmonary response to endotoxin. J Appl Physiol 1967:23:47-52

Stengert KB, Wilsey BL, Hurley EJ, Grehl TM, Lurie AJ, Klein RC, Upjohn LR. Incremental intravenous nitroglycerin for control of afterload during anesthesia in patients undergoing myocardial revascularization. Anaesthesist 1978;27:223-227

Stinson EB, Holloway EL, Derby G, Oyer PE, Hollingsworth J, Griepp RB, Harrison DC. Comparative hemodynamic responses to chlorpromazine "nitroprusside, mitroglycerin, and trimetaphan immediately after open-heart operations. Circulation 1975;51(suppl $1): 26-33$

Stoelting RK. Viegas O, Capbell RL. Sodium nitroprusside-produced hypotension during anesthesia and operation in the headup position. Anesth Analg $1977 ; 56: 391-394$

Stott DJ, McLenachan JM, Ball SG. Ketanserin, the QT interval, and autonomic function testing in normal subjects. $\mathrm{Br} J$ Clin Pharmacall 1986;21:84P 
Styles M. Coleman AJ, Leary WP. Some hemodynamic effects of sodium nitroprusside. Anesthesiology 1973,38:173-176

Swan HJC, Ganz W, Forrester $J_{i}$ Marcus H, Diamond G, Chonette D. Catheterization of the heart in man with the use of a flow-directed balloon-tipped catheter. N Engl J Med $1970 ; 283: 447-451$

Swank RL: Hissen W, Bergentz SE. 5-Hydroxytryptamine and aggregation of blood elements after trauma. Surg Gynecol Obstet. 1964;119:779-783

Tarazi RC, Estafanous FG, Fouad FM. Unilateral stellate block in the treatment of hypertension after coronary bypass surgery. Am J Card 1978;42:1013-1018

Taylor KM, Morton U, Brown JJ, Bain WH, Caves PK. Hypertension and renin-angiotensin system following open heart surgery. J Thorac Cardiovasc Surg $1977,74: 840-845$

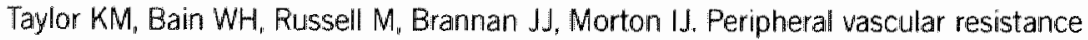
and angiotensin II levels during pulsatile and non-pulsatile cardiopulmonary bypass. Thorax 1979;34,594-598

Thomson $\mathbb{R}$, Mutch WA, Culligan JD. Failure of intravenous nitroglycerin to prevent intraoperative myocardial ischemia during fentanyl- pancuronium anesthesia.

Anesthesiology 1984;61-385-393

Thomson $\sqrt{A}$, Wei EP, Kontos HA. Inhibition by ketanserin of serotonin induced cerebral arteriolar constriction. Stroke 1984;15:1021-1024.

Thompson $C_{4}$ Forbes CD, Prentice CRM. The potentiation of platelet aggregation and adhesion by heparin in vitro and in wivo. Clin Sci Molecular Med 1973;45:485-494

Thys DM, Sivak $G$, Kaplan JA. The role of isosorbide dinitrate in the treatment of perioperative hypertension. Am Heart $」 1985 ; 110: 273-276$

Tinker JH, Michenfelder JD. Sodium nitroprusside: pharmacology, toxicology and therapeutics. Anesthesiology 1976;45:340-352 Torssell L, Sollevi A, Thorborg P Lund N. Skeletal muscle oxygen pressure fields during controlled hypotension with adenosine and sodium nitroprusside. Acta Anaesthesiol Scand 1986;30:93-96

Townsend GE, Wynands JE, Whalley DG, Bevan DR. Role of renin-angiotensin system in cardiopulmonary bypass hypertension. Can Anaesth Sac J 1984;31:160-165

Trenk D, Mosler A, Kirch W, Meinertz T, Jahnchen E. Pharmacokinetics and pharmacodynamics of the $5 \cdot \mathrm{HT}_{2}$ receptor antagonist ketanserin in man. $J$ Cardiovasc Pharmacal 1983:5:1034-1039

Triggle DJ, Swany VC. Pharmacology of agents that effect calcium. Chest 1980;78 (suppl):174-179 
Tuncer $M_{n}$ Dogan $N$, than $M$, Kayaalp SO. Serotonin-induced contraction of canine saphenous vein: mediation by $5 \cdot H \mathrm{~T}_{1}$ receptors. Arch Int Pharmacodyn $1985 ; 274: 305-312$

Tumbull KW, Miyagishima RT, Gerein AN. Pulmonary complications and cardiopulmonary bypass: a clinical study in adults. Can Anaesth Soc J $1974: 21: 181-186$

Turner $D A B$, Shribman $A J$, Smith $G_{1}$ Achola KJ. Effect of thalothane on cardiovascular and plasma catecholamine responses to tracheal intubation. Br J Anaesth $1986 ; 58: 1365-1370$

Tyler DC. Positive end-expiratory pressure: A review. Crit Care Med 1983;11:300-308

Utley JR, Stephens DB. Prevention of major perioperative neurological dysfunction-a personal perspective. Perfusion 1986;1:35-42

Van der Starre PJA, Scheiggrond HW, Reneman RS, Bach Kolling J. The use of ketanserin, a 5-hydroxytryptamine receptor antagonist, for treatment of postoperative hypertension following coronany artery bypass surgery. Anesth Analg 1983;62:63-69

Van der Starre PJA, Harinck-de Weerd JE, Reneman RS. Nitroprusside and ketanserin in the treatment of postoperative hypertension following coronary artery bypass grafting: a haemodynamic and ventilatory comparison. J Hypertension 1986;4(suppl 1): $107-110$

Van der Starre PJA, Reneman RS. The alpha-adrenegic receptor blocking effect of ketanserin and the interaction between alpha-adrenergic and $\mathrm{S}_{2}$-serotonergic receptor blocking. J Cardiovasc Pharmacol (in press)

VanderWoude JC, Christlieb IY, Kao RL, Clark RE. Ketanserin provides improved myocardial protection. Surg Forum 1983;34:307-309

Van de Water $A$, Wouters $L$, Xhonneux $R$, Reneman RS. Cardiovascular effects of ketanserin in closed-chest anesthetized dogs. Arch Int Pharmacodyn Ther $1985 ; 275: 267-278$

Vanhoutte PM. Can peripheral serotonergic blockade explain the hypotensive effect of ketanserin? J Cardiovasc Pharmacol 1985;7(suppl 7):105-109

Vanhoutte PM, van Nueten JM, Symoens J, Janssen PAJ. Antihypertensive properties of ketanserin (R41468). Fed Proc 1983a;42:182-185

Vanhoutte PM. 5-Hydroxytryptamine and vascular disease. Fed Proc $1983 b ; 42: 233-237$

Van Nueten JM, Reneman RS, Janssen PAJ. Specific alpha-adrenoreceptor blocking effect of droperidol on isolated smooth muscles. Eur J Pharmacoll 1977;44:1-8 
Van Nueten $\mathrm{JM}_{\text {, Xhonneux }} \mathrm{R}_{\text {, Vanhoulte }}$ RM $\mathrm{M}_{i}$ Janssen PAJ. Vascular activity of ketanserin (R41468), a selective $5-\mathrm{HT}_{2}$ receptor antagonist. Arch Int Pharmacodyn Ther 1981a;250:328-329

Van Nueten JM. 5-Hydroxytryptamine and precapillary vessels. Fed Proc $1983 a ; 42: 223 \cdot 227$

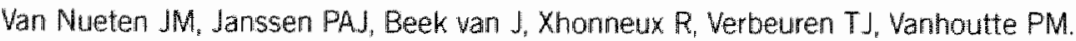
Vascular effects of ketanserin (R41468), a novel antagonist of $5-\mathrm{HT}_{2}$ serotonergic receptors. J Pharmac Exp Ther 1981 b;218:217-230

Van Nueten $\mathrm{JM}_{\mathrm{t}}$ Janssen PAJ, De Ridder W, Vanhoutte PM. Interaction between 5-hydroxytryptamine and other vasoconstrictor substances in the isolated femoral artery of the rabbit: effect of ketanserin (R41468). Eur J Pharmacol $1982 ; 77: 281-287$

Van Nueten JM, Vanhoutte PM. Selectivity of calcium-antagonism and serotonin-antagonism with respect to wenous and arterial tissues. Angiology $19810 ; 32: 467-484$

Van Nueten JM, Leysen JE, Schuurkes JAJ, Vanhoutte PM. Ketanserin: a selective antagonist of 5-HT, serotonergic receptors. Lancet 1983;5:297-298.

Van Nueten JM, Janssen PAJ, Vanhoutte PM. Pharmacological properties of serotonergic responses in vascular, bronchiall, and gastrointestinal smooth muscle. Vascular Neuroeffector Mechanisms: $4^{\text {th }}$ Int Symp.Ed: J.A.Bevan, Raven Press, N.Y., $1983: 243-250$

Van Nueten JM, De Ridder W, Vanhoutte PM. Ketanserin and vascular contractions in response to cooling. Eur J Pharmacol 1984;99:329-332

Van Nueten JM, Wellens D. Tissue specificity of calcium antagonistic properties of lidoflazine. Arch int Pharmacodyn 1979.242:329-331

Van Nueten JM, Xhonneux $R$, Janssens WJ, Schuurkes JAJ, Janssen PAJ. Interaction between $S_{2}$-serotonergic and alpha-, adrenergic receptors and controll of blood pressure. In: Mechanisms of Vasodilatation IV, Rochester, Minn.1986.Abstract.

Van Wezel HB, Bovill JG, Schuller J , Giellen J, Hoeneveld MH. Comparison of nitroglycerine, verapamil and nifedipine in the management of arterial pressure during coronary artery surgery. Br J Anaesth 1986;58:267-273

Van Zwieten PA, De Jonge A, Wilffert B. Timmermans PBMWM, Beckeringh JJ. Thoolen MUMC. Cardiovascular effects and interaction with adrenoceptors of urapidil. Arch int Pharmacodyn Ther 1985:276:180-181 
Velders AJ, van den Dungen JJAM, Westerhof NJW, Wildewuur CRH. Platelet damage by protamine administration: protection by reducing protamine or by prostacyclin (PG12) treatment. Eur Surg Res 1980;12(suppl):50-51

Viljoen JF, Estafanous FG. Acute hypertension immediately after coronary artery surgery. IThorac Cardiovasc Surg 1976;71:548-550

Vincent JL, Degaute JP, Domb M, Simon P, Berre J, Vandesteene A, Ketanserin, a serotonin antagonist. Chest 1984;4:510-513

Wagner $\mathrm{RL}$, White PF. Etomidate inhibits adrenocortical function in surgical patients. Anesthesiology 1984:61:647-651

Walker JM. Wilmshurst PT, Juul SM, Coltart DJ. Acute effects of ketanserin on left ventricular function, metabolism and coronary blood flow. Br J Clin Pharmac $1984 ; 17: 301-307$

Wallach R, Karp RB, Reves JG, Oparil S, Smith PR, James TN. Pathogenesis of paroxysmai hypertension deweloping during and after coronary bypass surgery: a study of hemodynamic and humoral factors. Am J Card 1980;46:559-565

Wanscher $M_{n}$ Tonnesen $E$. Huttel $M_{1}$, Larsen K. Etomidate infusion and adrenocortical function: a study in elective surgery. Acta Anaesthesiol Scand 1985:29:483-485

Wauquier A Ashton D. Clincke G, Niemegeers CJE. Antihypoxic effects of etomidate, thiopental and methohexital. Arch Int Pharmacodyn Ther 1981;249:330-334

Wauquier A. Prafile of etomidate. A hypnotic, anticonvulsant and brain protective compound. Anaesthesia 1983;38 (suppl):26-33

Weiner CP, Socol ML, Vaisrub N. Controll of preeclamptic hypertension by ketanserin, a new serotonin receptor antagonist. Am J Obstet Gynecol 1984a;149:496-500

Weiner CP, Gelian R, Socol ML. Intrapartum treatment of preeclamptic hypertension by ketanserin - a serotonin receptor antagonist. Am J Obstet Gynecol $1984 b ; 149.576-578$

Weinstein GS, Zabetakis PM, Clavel A, Franzone A, Agrawal M, Gleim G, Michelis M, Wallsh $\mathbb{E}$. The renin-angiotensin system is not responsible for hypertension following coronary artery bypass grafting. Ann Thorac Surg 1987;43:74-77

Wenting GJ, Woittiez A.JJ, Man in "t Veld AJ, Schallekamp MADH. 5-HT, alpha-adrenoceptors, and blood pressure. Effects of ketanserin in essential hypertension and autonomic insufficiency. Hypertension 1984;6:100-109

Wenting GJ, Man in "t Veld A.J, Woittiez AJ, Boomsma F, Schalekamp MADH. Treatment of hypertension with ketanserin, a new selective $5-\mathrm{HT}_{2}$ receptor antaganist. Br Med J1982a:284:537-539 
Wenting GJ Man in 't Veld AJ, Woittiez AJ, Boomsma F. Schalekamp MADH. Haemodynamic effects of ketanserin, a new selective 5-hydroxytryptamine (serotonin) receptor antagonist, in essential hypertension. Clin Sci 1982b,63(suppl 8):435-438

Wenzel $\mathbb{E}$, Wokmer I, Laux E, Limbach HG. Blood trauma and hypercoaguability produced by extracorporeal circulation. In: Schmid-Schonbein $H$, Teitel $P$, eds. Basic aspects of blood trauma. The Hague, Martinus Nijhoff Publishers, 1979"159-183

Whitwam $J G$, Russell WJ. The acute cardiovascular changes and adrenergic blockade by droperidol in man. Br J Anaesth 1971;43:581-591

Wildsmith JAW, Marshall RL, Jenkinson JL, McRae WR, Scott DB. Haemodynamic effects of sodium nitroprusside during nitrous oxide/halothane anaesthesia. Br J Anaesth $1973 ; 45: 71-74$

Williams DJM, Morgan R.MM, Major E. Urapidil in the treatment of hypertension following coronary artery bypass surgery. Br J Anaesth 1985;57:427

Wing LMH, Chalmers JP, West MJ, Bune AJ, Ayres B, Graharn JR. The effect of ketanserin on blood pressure and biochemical parameters in treated patients with essential hypertension. Clin Exp Hyper 1984;A6(6):1107-1117

Wolf WA, Kuhin DM, Lovenberg W. Blood pressure responses to local application of serotanergic agents in the nucleus tractus solitarii. Eur J Pharmacol $1981 ; 69: 291-299$

Wurzinger LJ, Baldauf $W_{1}$ Tobias. E, Mottaghy K. Species differences in platelet aggregation with special reference to heparin as anticoagulant, In: Basic aspects of blood trauma, H Schmid-Schonbein, ed, Martinus Nijhoff Publ, The Hague, 1979, 80

Wycoff $C O$. Endotracheal intubation: effects on blood pressure and pulse rate: Anesthesiology 1960;21:153-158.

Wynands JE, Wong P, Whalley DG, Sprigge JS, Townsend GE, Patel YC. Oxygen-fentanyl anesthesia in patients with poor left ventricular function: hemodynamics and plasma fentanyl concentrations. Amesth Analg 1983;62:476-82

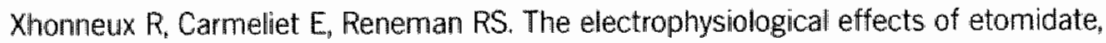
a new, short-acting hypnotic, in various cardiac tissues. In: Recent Progress in Anesthesiology and Resuscitation. Excerpta Medica, Amsterdam, 1974; pp 157-161

Yaster $M$, Simmons RS, Tollo VT, Pepple JM, Wetzel RC, Rogers MC. A comparison of nitroglycerin and nitroprusside for inducing hypottension in children: a double-blind study. Anesthesialogy 1986;65:175-179

Yriola H. Comparison of haemodynamic effects of morphine and fentanyl in patients with coronary artery disease. Acta Anaesthesiol Scand 1983;27:117-122 
Zabiudowski JR, Ball SG, Robertson JIS. Ketanserin and alpha -adrenergic antagonism in humans. J Cardiovasc Pharmacol 1985;7(suppl 7):123-125

Zabludowski JR, Zoccali $C_{\text {s }}$ Isles CG, Murray GD, Robertson JIS, Inglis GC, Fraser R, Ball SG. Effect of the 5-hydroxytryptamine type-2 receptor antagonist, ketanserin, on blood pressure, the renin-angiotensin system and sympatho-adrenal function in patients with essential lhypertension. Br J Clin Phamacol 1984;17:309-316

Zener JC, Hancock EW, Shumway NE, Harrison DC. Regression of extreme pulmonary hypertension after mitral valve surgery. Am 」 Cardiol 1972;30:820-827

Zoccali C, Zabludowski JR, Isles CG, Murray GD, Inglis GC, Robertson JIS, Fraser $R$, Ball SG. The effect of a $5 H T$ antagonist, ketanserin, on blood pressure, the renin-angiotensin system and sympatho-adrenal function in normal man. Br J Clin Pharmacol 1983; 16:305-311

Zucker MB. Effect of heparin in platelet function. Thromb Diathes Haemorrh $1974 ; 33: 53-65$

Zurick AM, Wagner RH, Starr NJ, Lytle B, Estafanous FG. Intravenous nitroglycerin, methemoglobinemia, and respiratory distress in a postoperative cardiac surgical patient. Anesthesiology 1984;61:464-466 



\section{Acknowledgements}

I would like to express my thanks to all those people who gave me the opportunity to perform the studies. I would especially like to thank:

Professor Dr. R.S. Reneman, who acted as a perfect guide through this complicated world of medical science. His well-considered remarks and suggestions encouraged me to try to continuously improve the manuscript.

Professor Dr. J.G. Bovill and Professor Dr. S. de Lange, who were so kind to accept to be referent and to spend considerable time in reviewing the manuscript.

My colleagues from the Department of Anesthesiology, who willingly cooperated to carry out the studies.

The cardiac surgeons, who supported the project by permitting me to perform the studies on their patients.

Dr. P. de Leeuw for his contribution in the laboratory assays in chapter 4. The nurses and technicians from the operating room, intensive care and laboratory, who were of much help by their effort, interest and enthousiasm during the studies.

Dr. J. Smakman, Drs. R. Felt and Mr. H. Scheijgrond, who provided important assistance in executing the statistics and graphics.

I would like to express my special thanks to Mrs. Karen van Driel for her excellent secretarial and editing assistance.

Last but not least I would like to thank my wife Annèt and the children for their patience and endurance to sustain the sometimes difficult periods of blood, sweat and tears during the different stages of the studies. 



\section{Curriculum vitae}

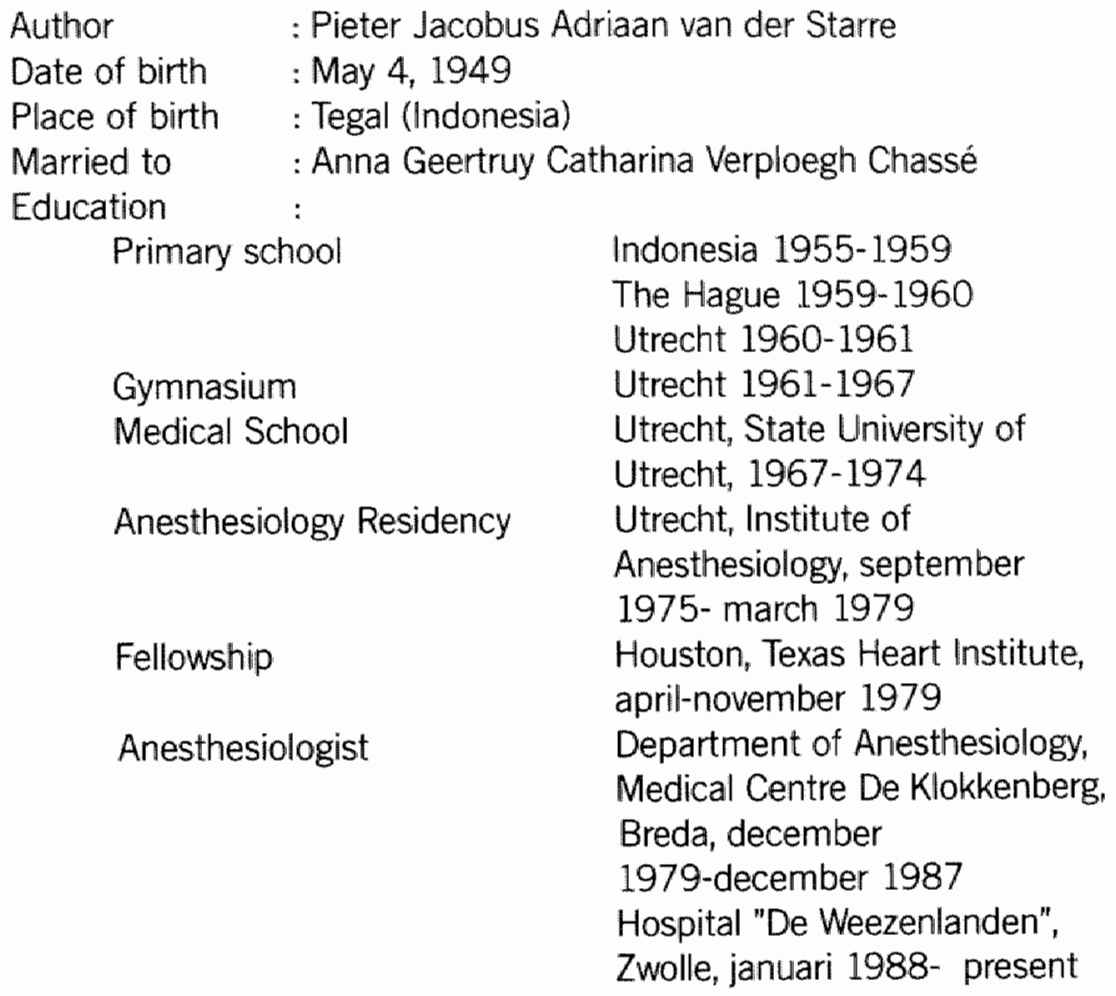

